\title{
6. GLACIAL/INTERGLACIAL CYCLES IN THE NORWEGIAN SEA: SEDIMENTOLOGY, PALEOCEANOGRAPHY, AND EVOLUTION OF LATE PLIOCENE TO QUATERNARY NORTHERN HEMISPHERE CLIMATE1
}

\author{
Rüdiger Henrich ${ }^{2}$
}

\begin{abstract}
The long-term record of glacial/interglacial cycles indicates three major paleoceanographic regimes in the Norwegian Sea. The period since the first major glaciation over Scandinavia at $2.56 \mathrm{Ma}$ is characterized by high-frequency, low-amplitude oscillations of ice-rafted debris inputs, a lowered salinity, and decreased carbonate shell production in surface waters as well as overall strong carbonate dissolution at the sea floor. These conditions indicate a more zonal circulation pattern in the Northern Hemisphere and a relative isolation of surface and bottom waters in the Norwegian Sea. The generally temperate glacial climate was only interrupted by episodic weak intrusions of warm Atlantic waters. These intrusions have been detected in considerable magnitude only at Site 644 , and thus are restricted to areas much closer to the Norwegian shelf than during earlier periods. The interval from 1.2 to $0.6 \mathrm{Ma}$ is characterized by an increase in carbonate shell production and a better preservation, as well as a change in frequency patterns of ice-rafted debris inputs. This pattern reflects increasing meridionality in circulation-strengthening contrasts in the Norwegian Sea between strong glaciations and warm interglacials. The past $0.6 \mathrm{Ma}$ reveal high-amplitude oscillations in carbonate records that are dominated by the 100-k.y. frequency pattern. Glacial/interglacial sedimentary cycles in the ODP Leg 104 drill sites reveal a variety of specific dark lithofacies. These dark diamictons reflect intense iceberg rafting in surface waters fed by surges along the front of marine-based parts of the continental ice sheets in the southeastern sector of the Norwegian Sea and are associated with resuspension of reworked fossil organic carbon and strong dissolution at the sea floor. Piling up of huge iceberg barriers along the Iceland-Faeroe-Scotland Ridge might have partially blocked off surface water connections with the North Atlantic during these periods.
\end{abstract}

\section{INTRODUCTION}

\section{Purpose of Study}

Results from Leg 104 show that drastic and sudden changes in surface- and deep-water circulation, vertical mixing, and bottom-water ventilation resulted in cyclic shifts of glacial and interglacial sedimentary environments in the Norwegian Sea since $2.56 \mathrm{Ma}$. These changes include strong fluctuations of the Norwegian Current, the areal extent of sea ice, and the dominant pathways of iceberg drift. Prior to Leg 104, evidence on the onset and variability of Northern Hemisphere glaciations relied mainly on results from various North Atlantic drill sites, e.g., Site 552 (Shackleton et al., 1984), and Leg 94 (Ruddiman, Kidd, et al., 1986). The principal data used in these studies were highresolution stable isotope and carbonate records accompanied by records of the total amount of the noncarbonate coarse fraction. An increasing number of studies on undisturbed piston cores during the last $10 \mathrm{yr}$ (e.g., Belanger, 1982; Streeter et al., 1982; Kellogg, 1975; 1976; 1977; Kellogg et al., 1978) elucidated environmental changes within the last three to four glacial/interglacial cycles in great detail and proposed reconstructions of Norwegian-Greenland Sea paleoceanography for the last 400 k.y.

The purpose of this study is to present new sedimentological evidence for variability of Northern Hemisphere glaciations during the last $2.56 \mathrm{~m} . \mathrm{y}$. and to test and modify published models of Norwegian Sea paleoceanography for the last 400 k.y. (Kellogg, 1980; CLIMAP, 1976; 1981; and Ruddiman and McIn-

\footnotetext{
${ }^{1}$ Eldholm, O., Thiede, J., Taylor, E., et al., 1989. Proc. ODP, Sci. Results, 104: College Station, TX (Ocean Drilling Program).

2 Geologisch-Paläontologisches Institut, Universität Kiel, Olshausenstr. 40, D-2300 Kiel, Federal Republic of Germany: now at: GEOMAR, Forschungszentrum für Marine Geowissenschaften an der Universität Kiel, Wischhofstr. 1-3, D2300 Kiel, Federal Republic of Germany.
}

tyre, 1977; 1981). A different methodological approach, based on recognition and careful description of various glacial-, interglacial-, and deglaciation lithofacies types and their regional and temporal distribution is established in this study. This approach required an extension of the sedimentological data base and methods. The methods applied include radiograph analysis, measurements of carbonate (total, coarse, fine), organic carbon, and major elements (e.g., $\mathrm{Fe}$ and Mn contents of the bulk sediments), grain-size analysis, microscopic analysis of the major coarse-fraction components, and SEM studies on carbonate preservation, e.g., SEM dissolution indices on left-coiling $N$. pachyderma.

\section{Regional Oceanography and its Representation in Surface Sediments}

The present-day surface circulation of the Norwegian-Greenland Sea is dominated by two main current systems (Fig. 1); the inflow of warm saline North Atlantic surface water (NAW) between Iceland and the Shetlands (Norwegian Current) and the inflow of cold polar surface water and sea ice through the Fram Strait (East Greenland Current). Along the Norwegian coast the Norwegian Coastal Current carries water of less than 35\% salinity northward, which in spring is further diluted down to $32 \%$ because of high runoff from the fjords. The Norwegian Current follows the Norwegian continental margin and divides near Bear Island into two branches.

The East Greenland Current occupies a broad area along the eastern margin of Greenland and leaves the Norwegian-Greenland Sea through the Denmark Strait (Fig.1). Between these two major current systems, a wide area in the center of the Greenland and Iceland Sea is occupied by a mixed surface-water layer called arctic surface Water (ASW). This water mass has a low salinity and is cold with strong variations in both temperature and salinity (Johannessen, 1986). Large eddies of cold and warm water form along the boundary of the Norwegian Current and the East Greenland Current and drift into the ASW domain. 


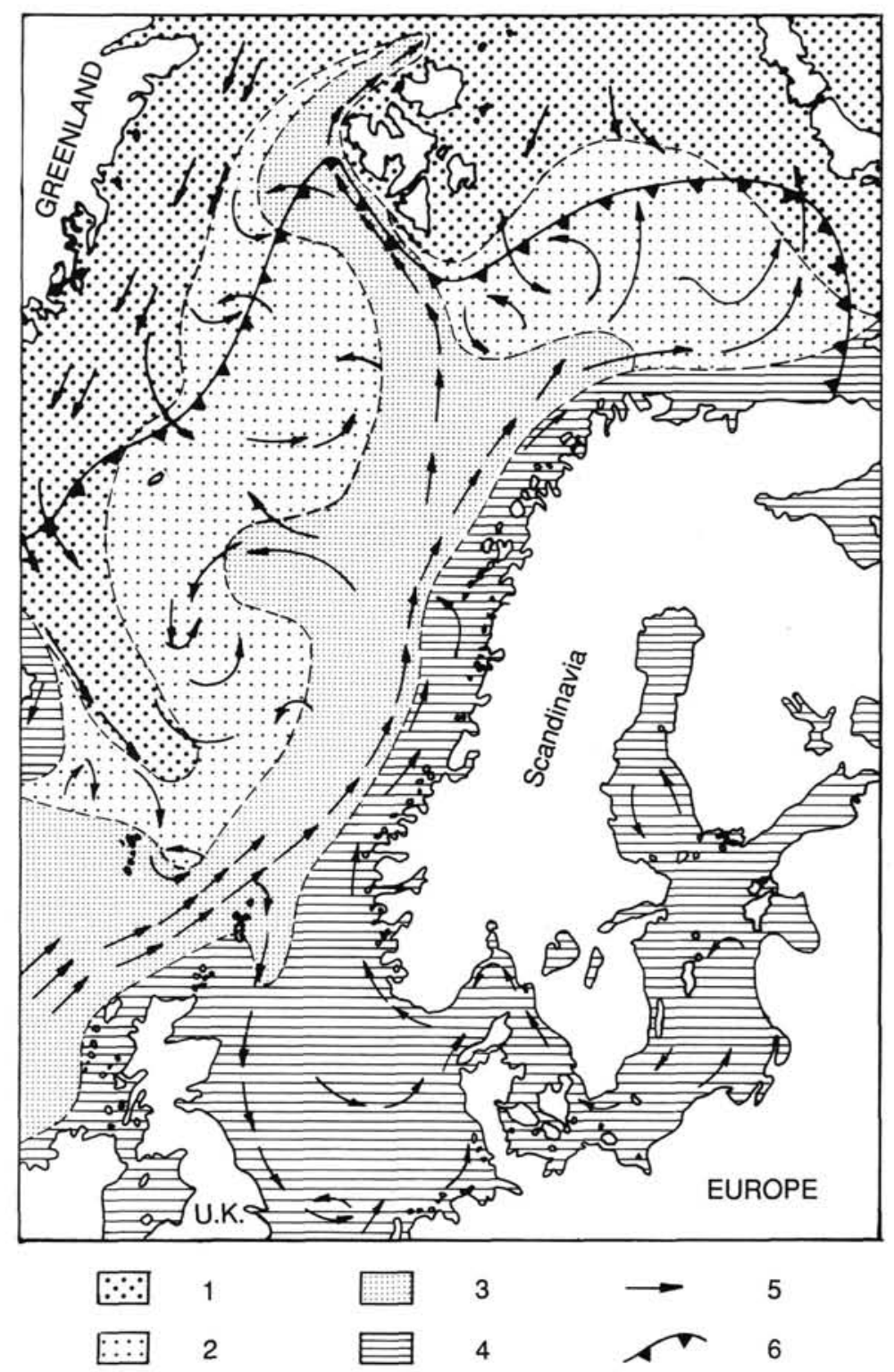

Figure 1. Map showing the surface waters and the main circulation pattern in the Norwegian Sea and adjoining seas. $1=$ arctic water, $2=$ mixing water, $3=$ Atlantic water (water in the Norwegian Current, NC), $4=$ coastal, Baltic, and North Sea water (water in the Norwegian Coastal Current, NCC) $5=$ surface currents, 6 = sea-ice border in April.

Between Svalbard and Jan Mayen the high-salinity Atlantic water becomes so dense from surface cooling that it sinks and fills the abyss of the Norwegian-Greenland Sea. During winter, regional overturning of dense surface water and less-dense deep water in the Greenland Sea may result in a deep convection and contribute to deep-water formation (Johannessen, 1986; Swift, 1986). Additionally, dense water formed on the Barents shelf in winter during sea ice formation flows down the continental slope into the Bear Island Trough (Sarynina, 1972). Newly formed deep water leaves the Norwegian-Greenland Sea through deeper sections of the Denmark Strait and over sills between Iceland and the Shetland Islands forming the prominent middle water mass in the Atlantic ocean called North Atlantic deep water (NADW) Worthington, 1970; Meincke, 1983).

Surface sediments on the floor of the Norwegian-Greenland Sea reflect the major surface-water circulation pattern (Gor- shkova, 1960, Kellogg, 1975). High carbonate-shell productivity, e.g., high contents of planktonic foraminifers and coccolithophoroids, are found under the Norwegian Current. Higher amounts of the relatively warm-water species, e.g., right-coiling $N$. pachyderma and other subpolar species, conform to temperature gradients in the warm Atlantic current system (Kellogg, 1975). The coastal areas off Norway and Greenland are dominated by terrigenous clays and sands, most of which have been extensively affected by winnowing of the fine fraction due to bottom-current activity. Most of the sediments consist of relict Pleistocene material deposited on the shelf either by ice rafting or as till (Holtedahl and Bjerkli, 1975; Vorren et al., 1984). Little or no ice-rafted debris, but commonly foraminifer clays are observed in a band west of Svalbard and a band south of Svalbard towards Greenland (Vogt, 1986), areas which today are covered by winter sea ice. This might indicate that the transport capacity of 
terrigenous debris by sea ice is only of local importance, e.g., in shallow shelf regions where an incorporation of terrigenous material in and onto the sea ice is possible.

Today most parts of the Norwegian Sea are well above the CCD and the CCL (Kellogg, 1975, Henrich, 1986) because of intense deep-water formation. Rapid exchange of deep water prevents an enrichment of $\mathrm{CO}_{2}$ in bottom water. Toward the continental shelf, an increase in Holocene supralysoclinal dissolution is observed, resulting from a higher consumption rate of organic matter by benthic and bacterial activity (Henrich, 1986).

\section{Previous Studies and Models on Glacial/Interglacial Paleoceanography}

In contrast to sparse documentation of late Pliocene and early Pleistocene glaciations, the youngest glacial/interglacial cycles have been investigated in great detail in various studies. Several hundred box and piston cores have been recovered from the Norwegian-Greenland Sea deep-sea areas. In addition, an even larger number of short cores have sampled shelf sediments along the Norwegian, Greenland, and Svalbard continental margins.

The comprehensive studies by Kellogg $(1975,1976,1977)$ and Kellogg et al. (1978) contain the most complete published records of the last $450 \mathrm{k} . \mathrm{y}$., combining basic sedimentological and stable isotopic data with faunal abundances and their compositional differences. In a synthesis study, Kellogg (1980) provided synoptic charts of sea-surface temperature distribution based on calculations using temperature transfer functions for various glacial/interglacial periods of the Norwegian-Greenland Sea (Imbrie and Kipp, 1971).

The essential indications of these charts are that during the last glacial maximum, 18 k.y. ago, the Norwegian-Greenland Sea remained permanently sea-ice covered, the ice being driven around by a single weak sluggish gyre. During stage $5 \mathrm{a}$, the transition from the last interglacial to the last glacial about 82 k.y. ago, a weak two-gyre system is indicated, showing most of the Norwegian Sea permanently ice covered with exception of a narrow tongue of seasonal ice cover in the central parts. The last interglacial maximum (stage 5e, 124-115 ka) had circulation patterns similar to today, but stronger. This situation is thought not to have occurred again during the last $450 \mathrm{k}$.y.

A modified view of the above circulation patterns was presented by Belanger (1982). He suggested the existence of warm, productive subpolar waters throughout isotope stages 1 and 5 and in parts of stage 4 based on combined coccolith, benthic, and planktonic foraminifer evidence. Productivity, assumed to be considerably lower during stages 2 and 3, was interpreted to be consistent with year-round ice cover.

Streeter et al. (1982) concluded that the glacial Norwegian Sea in the last 130 k.y. could not have been a sink for dense surface water and thus not a source of deep-water overflow. Evidence for this conclusion consisted of correlation of benthic foraminifer faunas and oxygen isotope stratigraphy indicating warmer bottom waters than today.

In the last $10 \mathrm{yr}$ various studies have concentrated on the mechanism of the last deglaciation. Ruddiman and Glover (1975) and Ruddiman and McIntyre (1981) demonstrated that the deglacial warming of the high-latitude North Atlantic occurred in three steps; 13 k.y. ago in the southeast sector, 10 k.y. ago in the central and northern sector, and 9 to $6 \mathrm{k} . \mathrm{y}$. ago in the Labrador Sea. Recent high-resolution studies of the last deglaciation period in the Norwegian Sea indicate a complex pattern of changes in surface- and bottom-water circulation which were partly out of phase with the North Atlantic. Before 12 k.y. ago, ice rafting and low carbonate productivity dominated the surface-water environment (Jansen et al., 1983; Sejrup et al., 1984; Henrich, 1986), while reduced deep-water circulation (Jansen and Erlenkeuser, 1985 ) resulted in increased carbonate dissolution (Henrich, 1986).
About 12 k.y. ago strong advection of warm water is reflected by high diatom productivity and the first reappearance of coccoliths and radiolarians in the southern Norwegian Sea (Jansen and Bjørklund, 1985). Deep-water circulation may have been reinitiated shortly after $12 \mathrm{k}$.y. ago as carbonate dissolution gradually diminished during termination $1 \mathrm{~b}$ (10-8 k.y. ago) (Henrich, 1986). Icebergs still occurred in surface waters over the Vøring Plateau reducing carbonate shell production during termination $1 b$ (10 k.y. ago). Since then a gradual elevation of carbonate productivity is observed (Henrich, 1986).

On the shelf off northern Norway, deposition of basal tills during the Weichselian was followed by a laminated clay sequence sedimented in an environment dominated by sea ice (Vorren et al., 1984). Subsequently, iceberg plowing on banks and deposition of pebbly and sandy pelites in troughs took place. Winnowing of bank sediments occurred since about 13 k.y. ago and was accelerated at the beginning of the Holocene. At that time, intrusion of Atlantic water marked environmental and faunal changes (Vorren et al., 1984).

\section{Regional Setting of the ODP Leg 104 Drill Sites}

The Vøring Plateau is a prominent feature of the Norwegian continental margin (Fig. 2). It is a marginal high with an almost flat top at about $1300-1400 \mathrm{~m}$, surrounded by the Norwegian shelf (200-400 m deep) to the east, the Lofoten Basin (about $3000 \mathrm{~m}$ deep) to the north and west, and by the Norwegian Basin to the south (about $2500 \mathrm{~m}$ deep). The three drill sites of Leg 104 form a short transect roughly perpendicular to the Vøring Plateau continental margin. A deep-water site (643) is situated at $2753 \mathrm{~m}$ water depth at the lowermost part of the slope of the Vøring Plateau, toward the Lofoten Basin. Site 642 is located at the outer Vøring Plateau in a slightly elevated area of the almost flat plateau at $1286 \mathrm{~m}$ water depth; Site 644 was drilled on the inner Vøring Plateau near the foot of the Norwegian continental slope at $1227 \mathrm{~m}$ water depth. The main surface-water mass over the Vøring Plateau is the Norwegian Current, bordered by the Norwegian Coastal Current near the Norwegian shelf. Deep-water masses include Norwegian Sea deep water and Norwegian Sea bottom water. The maximum depth of the Norwegian Current is about 500 to $700 \mathrm{~m}$.

\section{METHODS}

\section{Sample handling}

All three sites were sampled densely in the sections dominated by glacial/interglacial cycles. In Holes $642 \mathrm{~B}$ and $642 \mathrm{C}$, four samples per section were investigated with an average spacing of 30 to $40 \mathrm{~cm}$, equivalent to an age span of about 5 to 20 k.y. (depending on sedimentation rate). Sites 643 and 644 were used for a high-resolution study with seven samples per $150 \mathrm{~cm}$, equivalent to an age difference of about 5 to $10 \mathrm{k} . \mathrm{y}$. at Site 643 and 2 to 4 k.y. in Site 644 . All sample sizes were $20 \mathrm{~cm}^{3}$. Sites 643 and 644 samples were split and mostly processed in Bergen. Carbonate and organic carbon measurements for all samples were processed in Kiel. Sample handling procedures in the Kiel sedimentology laboratory are summarized in the flow diagram displayed in Figure 3. About 3 to $5 \mathrm{~cm}^{3}$ of each sample were separated for bulk carbonate, organic carbon, and element (e.g., Fe and $\mathrm{Mn}$ ) measurements. The remainder was disintegrated in a 10 to $20 \%$ ammonia-buffered hydrogen peroxide solution and afterward wet-sieved on a $63-\mu \mathrm{m}$ sieve. The residue was retained, dried and weighed. The fraction $>63 \mu \mathrm{m}$ was also dried and weighed, and than dry sieved into the following subfractions: 63-125 $\mu \mathrm{m}, 125-250 \mu \mathrm{m}, 250-500 \mu \mathrm{m}, 500-1000 \mu \mathrm{m},>1000 \mu \mathrm{m}$. The weights of individual subfractions and the weight loss during sieving were determined. Weight losses generally were less than $0.5 \%$.

\section{Carbonate, Organic Carbon, and Trace-element Measurements}

Bulk carbonate and organic carbon contents were determined on all samples from Site 642 and at least every second sample 


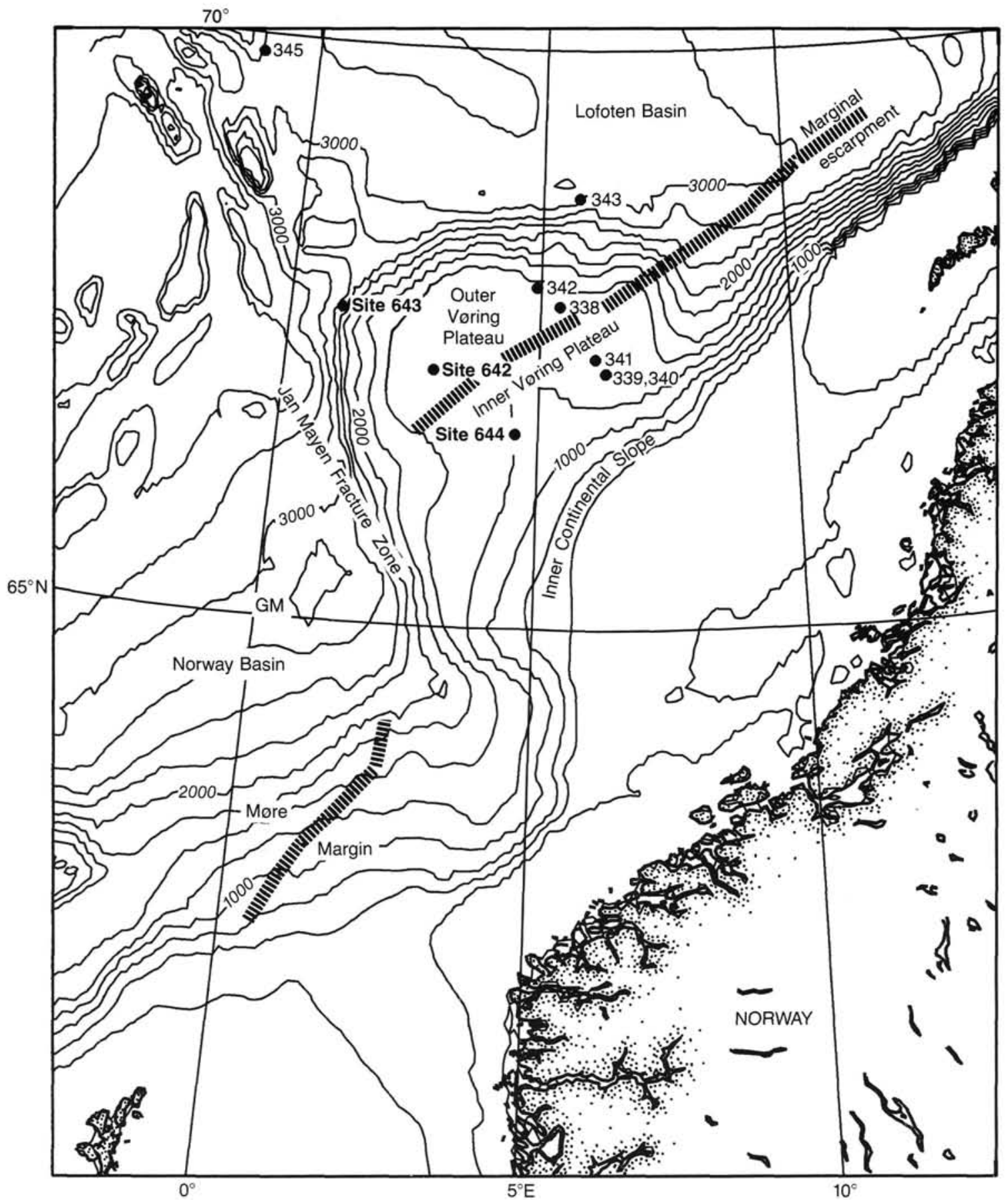

Figure 2. Position of Leg 104 drill sites (contours in meters).

from Sites 643 and 644 . Additionally, carbonate contents of the fraction $<63 \mu \mathrm{m}$ was determined for Holes $642 \mathrm{~B}$ and $643 \mathrm{~A}$ samples. Measurements were carried out with an infrared gas analyzer. This instrument uses photometric detection, utilizing infrared absorption of $\mathrm{CO}_{2}$ released from a sample after extraction of carbonate in phosphoric acid. Accuracy of these measurements is very high, with a standard deviation of less than $0.1 \%$ for both carbon and carbonate contents.

\section{Coarse-fraction and Grain-size Analysis}

About 500 to 700 grains from a representative sample split of the 125 - to $500-\mu \mathrm{m}$ fraction were counted and the predominant biogenic, terrigenous, and authigenic components were distinguished. The 125 - to $500-\mu \mathrm{m}$ fraction was chosen because results should be comparable to counts usually established in micropaleontological studies. Counting results of this subfraction may be regarded as best representing the major changes in both biogenic and terrigenous coarse-fraction components. Grain count percentages were corrected for the total amount of coarse fraction, to measure downcore changes in the same scale (e.g., weight percentages of bulk sediment). Horizontal scales of percentages of various individual particle groups were kept variable to attain a better resolution of details in the fluctuations. Grainsize distribution in the sediments may be approximated by a 


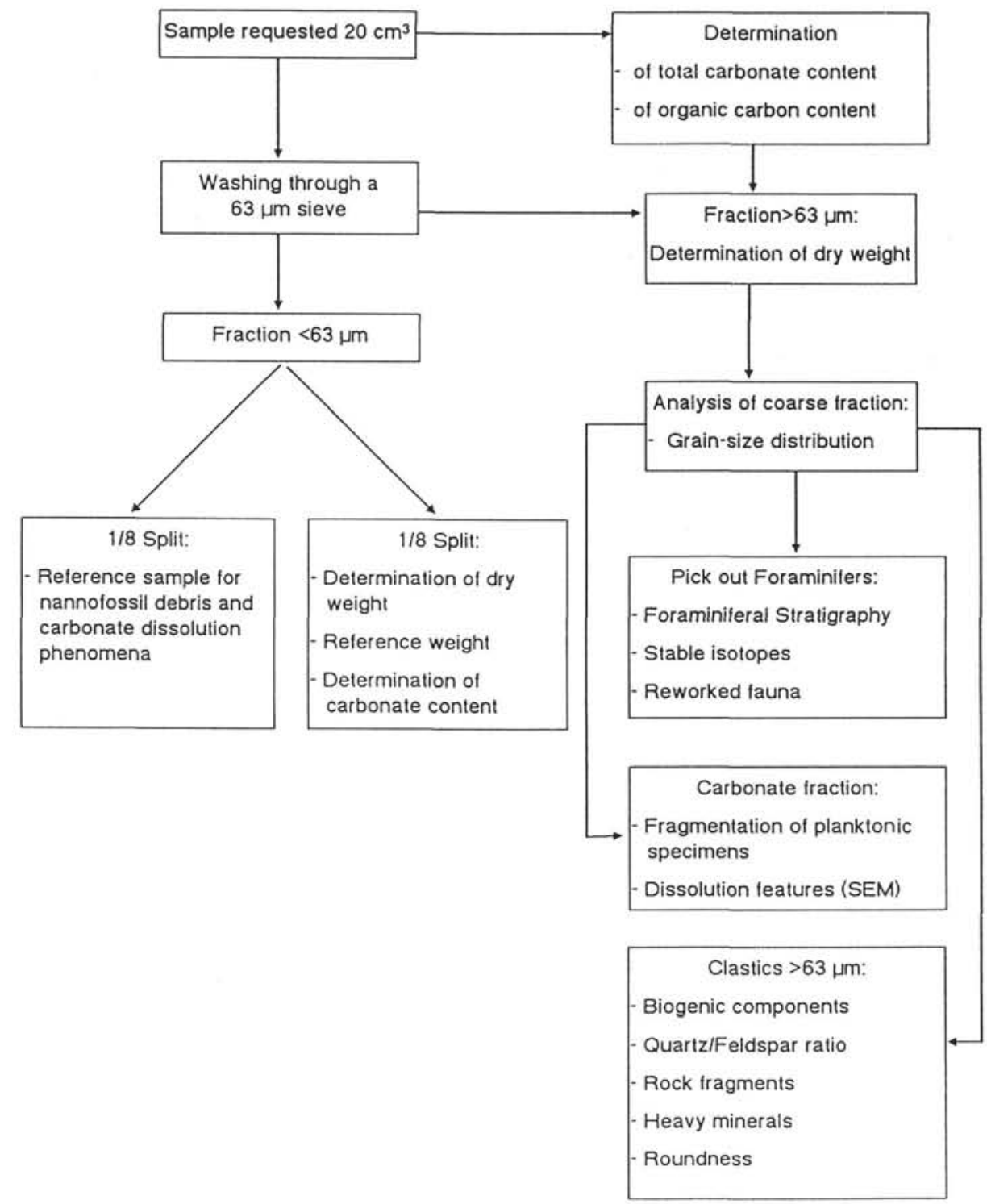

Figure 3. Flow diagram of sample processing in the sedimentological laboratory.

sum diagram displaying the cumulative percentages of the individual subfractions.

\section{SEM-dissolution Studies on $N$. pachyderma}

Most parameters commonly used for dissolution studies in low- and midlatitude oceans cannot be applied to polar and subpolar sediments because of the large variations in ecological conditions from glacial to interglacial stages in both surface-water and bottom-water environments. Moreover, the high-latitude pelagic sediments, like those generally in other regions, are affected by large fluctuations in the carbonate input from noncarbonate and reworked-carbonate sources, e.g., dilution by large inputs of terrigenous ice-rafted debris and by resuspension of ancient carbonate and mud from the shelf. Thus the equation established by Berger (1971) to determine the weight loss of carbonate during dissolution cannot be applied to this sedimentary environment, which largely relies on a constant input of a noncarbonate source. Benthic foraminifer associations react sensitively to changes in deep-water oceanography (Belanger and Streeter, 1980; Belanger, 1982; Streeter et al 1982; Sejrup et al.,
1984). Consequently, the plankton/benthos ratio also is inadequate in indicating dissolution. Large-scale differences in dissolution susceptability of various species of planktonic foraminifers were frequently used to establish dissolution rates (Berger, 1968; Crowley, 1983). Glacial planktonic foraminifers in high latitudes, however, have only a monospecific composition with left-coiled $N$. pachyderma. This is the only species that occurs in both glacial and interglacial sediments and is available for dissolution studies. We suggest that dissolution can be recorded by conventional fragmentation indexes of this species and by the more sensitive SEM-based dissolution indexes (Henrich, 1986).

The principles of the latter approach were described in Henrich (1986). It is based on the recognition of four stages of structural breakdown during progressive dissolution of the two morphotypes of $N$. pachyderma. In particular, the microcrystalline ultrastructure of reticulate forms and the coarse crystalline ultrastructure of crystalline forms with development of a typical secondary calcified crust are distinguished (details of the skeletal ultrastructure and mode of chamber formation in Kennett and Srinivasan, 1980; Henrich, 1986). During sediment trap experiments in the North Pacific, seasonal variations in the flux 
of crystalline and reticulate forms were detected showing the crystalline form adapted to waters colder than $8^{\circ} \mathrm{C}$ (Reynolds and Thunell, 1986).

The successive steps in dissolution are listed in Table 1 and are displayed in Plates 1 and 2. In many instances tests formed a transition between the two end members, typically with the youngest chamber being still reticulate while older chambers already are converted to the crystalline morphostructure. In these cases the most characteristically developed chambers were chosen for determination of the SEM-dissolution index to avoid confusion with transformation processes of the crust. Samples were processed for the SEM-investigations in the following way:

1. The sample was repeatedly split with a microprobe splitter until the remainder contained about $40-50$ tests.

2. Tests were mounted on a SEM carrier.

3. The degree of dissolution was determined for each test using the SEM and converted to dissolution steps as a numerical index.

4. A composite numerical dissolution index was calculated for each sample.

Dissolution susceptability for the reticulate and crystalline morphotype might differ slightly as discussed by Henrich (1986). However, the magnitude of this difference still has to be evaluated by in-situ dissolution experiments in the ocean similar to those car-

Table 1. Characteristic ultrastructural changes during progressive dissolution of $\boldsymbol{N}$. pachyderma sin. (SEM-defined dissolution indexes).

\begin{tabular}{|c|c|}
\hline Dissolution index & Indicative changes in ultrastructure of the tests \\
\hline $\mathrm{D}-0_{\mathrm{A}, \mathrm{B}}$ & Unaffected reticulate or crystalline tests. \\
\hline D-1 $\mathrm{A}$ & $\begin{array}{l}\text { Incipient dissolution of reticulations, preferen- } \\
\text { tially affecting chamber sutures and pores } \\
\text { of the outermost chambers. Dissolution of } \\
\text { the innermost primary calcitized wall } \\
\text { occurs simultaneously. }\end{array}$ \\
\hline D-2 A & $\begin{array}{l}\text { Selective removal of residual ridges with } \\
\text { granular calcite platelets. Often together } \\
\text { with formation of small superfical dissolu- } \\
\text { tion holes and cavities. }\end{array}$ \\
\hline D-3 A & $\begin{array}{l}\text { Strong dissolution and incipient fragmentation } \\
\text { often induced and enhenced by strong } \\
\text { dissolution from the inner chamber walls. } \\
\text { Steep corrosion relief on the test surfaces. }\end{array}$ \\
\hline D-1 B & $\begin{array}{l}\text { Incipient dissolution of the coarse skalenoedra } \\
\text { fabric with typical flame structures on the } \\
\text { crystal surfaces as well as preferential } \\
\text { dissolution along the rims of the crystals. } \\
\text { Advanced substages D-I B reveal irregular } \\
\text { ablation and corrosion on crystal surfaces. }\end{array}$ \\
\hline D-2 $\mathrm{B}$ & $\begin{array}{l}\text { Strongly from all sites corroded skalenoedra } \\
\text { associated with loosening of the densely } \\
\text { packed fabric of prisms. In this preserva- } \\
\text { tion stage parts of the test can easily be } \\
\text { removed by weak currents. Often this } \\
\text { stage is additionally characterized by deep } \\
\text { holes in the chamber walls and/or by } \\
\text { fracturing of weakened chambers. }\end{array}$ \\
\hline D-3 $\mathrm{B}$ & $\begin{array}{l}\text { Ghost structures of skalenoedra with very } \\
\text { intensive corrosion of crystals. The almost } \\
\text { intact test morphology can easily be } \\
\text { destroyed by any weak attack. Frequently } \\
\text { partial removal of crystals is observed. }\end{array}$ \\
\hline D-4 $A, B$ & $\begin{array}{l}\text { Final stage of corrosion. Complete disintegra- } \\
\text { tion of test into strongly corroded frag- } \\
\text { ments. }\end{array}$ \\
\hline
\end{tabular}

Abreviations: $\mathrm{A}=$ reticulate form of $\mathrm{N}$. pachyderma $\sin . \mathrm{B}=$ crystalline form of $N$. pachyderma sin.

Note: $N$. pachyderma form A often transforms its test during ontogenesis. In sediment samples, often many transitional reticulate/ crystalline forms are observed. Dissolution indexes should only be identified on typically developed chambers in this instance. ried out by Henrich and Wefer (1986) for shallow-water particles. Hence, the various steps of dissolution in this study are assumed to be equal for reticulate and crystalline forms. A composite numerical dissolution index is then calculated by the equation

$$
\begin{aligned}
d_{A, B}= & \left(d 0_{A, B} * n_{2}+d 1_{A, B} * n_{2} d 2_{A, B} * n_{3}+d 3_{A, B} * n_{4}\right) / \\
& \left(n_{1}+n_{2}+n_{3}+n_{4}\right)
\end{aligned}
$$

where

$$
\begin{aligned}
d_{A, B}= & \text { composite numerical dissolution index for } \\
& \text { the reticulate }(=A) \text { and crystalline }(=B) \\
& \text { morphotype of } N . \text { pachyderma sin., } \\
= & \text { dissolution steps (compare Table } 1) ; 0= \\
& \text { unaffected; } 3=\text { stronger dissolution; } 4= \\
& \text { only less than five tests left, and } \\
& \text { number of tests with dissolution index sub- } \\
& \text { scripted. }
\end{aligned}
$$

\section{Carbonate/Oxygen Isotope Stratigraphy, Sedimentation Rates and Accumulation Rates}

Good stratigraphic control on cores from polar seas is often hampered by various factors. Biostratigraphy in glacial/interglacial cycles of polar environments is of limited use because of the predominance of endemic and long-persistent faunal and floral assemblages. Furthermore, oxygen isotope stratigraphy on planktonic foraminifers can be hampered by salinity changes in surface waters (Jansen et al., in press; Jansen et al., this volume). However, paleomagnetic stratigraphy of the Leg 104 sediment sections containing glacial/interglacial cycles is well established (Bleil, this volume). With the exception of Site 643, the Brunhes/Matuyama and Matuyama/Gauss boundaries, as well as the Jaramillo and Olduvai subchrons, are readily defined (Figs. 6, 7, 8). At Site 643 the Olduvai subchron (Fig. 7) appearently is missing because of small slumps.

Based on this paleomagnetic framework we established a combined oxygen isotope and carbonate stratigraphy for all three sites for isotope stages 1 to 21 . Below 1 to $1.2 \mathrm{Ma}$ we lost stratigraphic control in Holes 642B, 642C, and 643A because of the almost complete loss of carbonate. Interglacial stages were mostly established when both light oxygen isotope values and high carbonate contents were observed. Stage boundaries were determined by comparing peak counts and curve shapes with the published carbonate and isotope records. All age determinations were established on the basis of the absolute age determinations for isotope stages in the SPECMAP time scale (Imbrie et al., 1984). They are listed in Table 2 and are displayed as age/ depth plots (Fig. 15). We stress, however, that a number of uncertanties remain in establishing reliable $\delta^{18} \mathrm{O}$ stage boundaries. Stratigraphic inconsistences in carbonate and oxygen isotope records are evident below 15 mbsf in Hole 643A (Fig. 7). The section above reveals remarkably conformable curve-shaped patterns in both records. The only difference is a short delay of early interglacial carbonate increase, which can be estimated as on the order of 3 to $5 \mathrm{k} . \mathrm{y}$. based on linear sedimentation-rate calculations (Fig. 7). In contrast, the section from 15 mbsf to 23 mbsf in Hole 643A often shows anticorrelated patterns of carbonate and oxygen isotope records of the planktonic foraminifer $N$. pachyderma. Light oxygen isotope values occur in sediments with low carbonate contents (Fig. 7) and often coincide with sections barren in benthic foraminifers (Fig. 12; Osterman, unpublished data). On the other hand, carbonate peaks correlate well with levels rich in benthic foraminifers (compare Osterman, unpublished data). Because at least some of these benthic foraminifers were adapted to well-oxygenated bottom waters, they have been found only in higher abundances during inter- 
Leg 104, Hole 642B $\% \mathrm{CaCO}_{3}$ Bulk

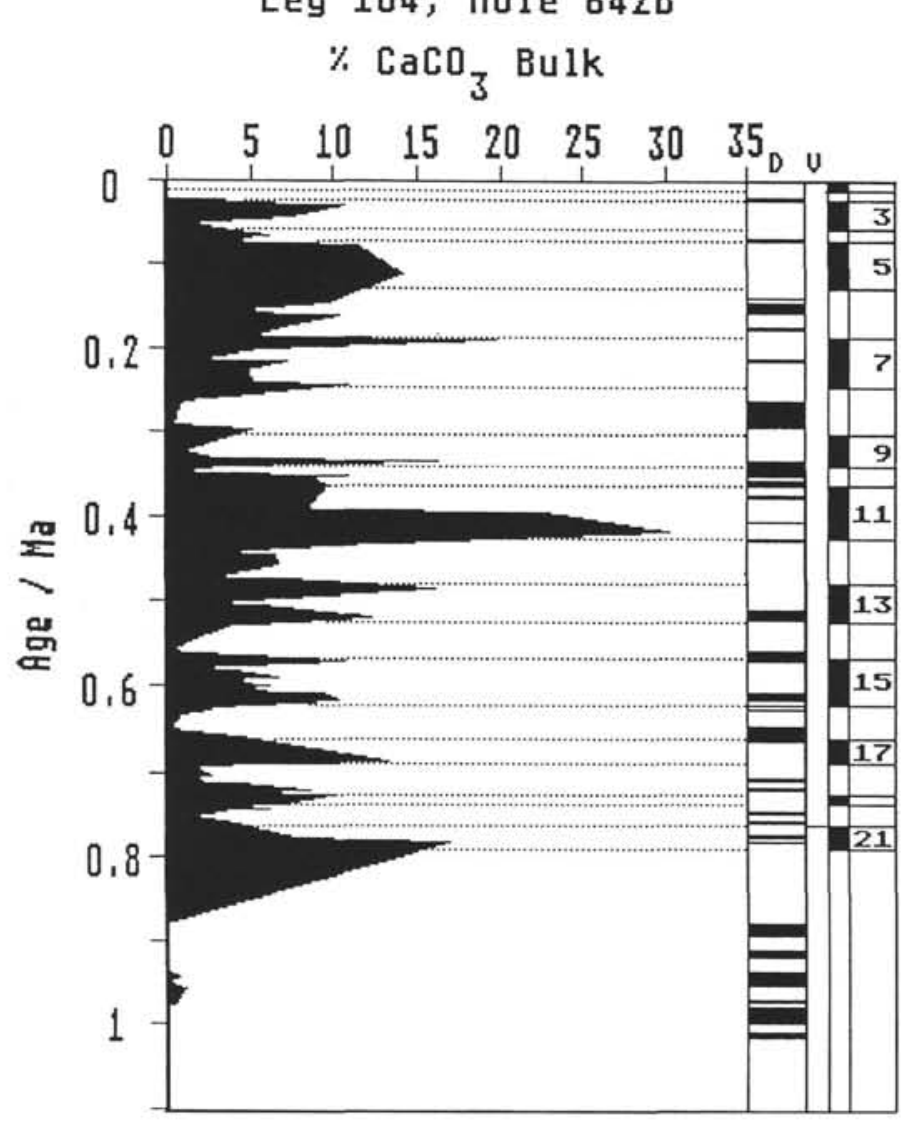

Leg 104, Hole 643A

$\% \mathrm{CaCO}_{3}$ Bulk

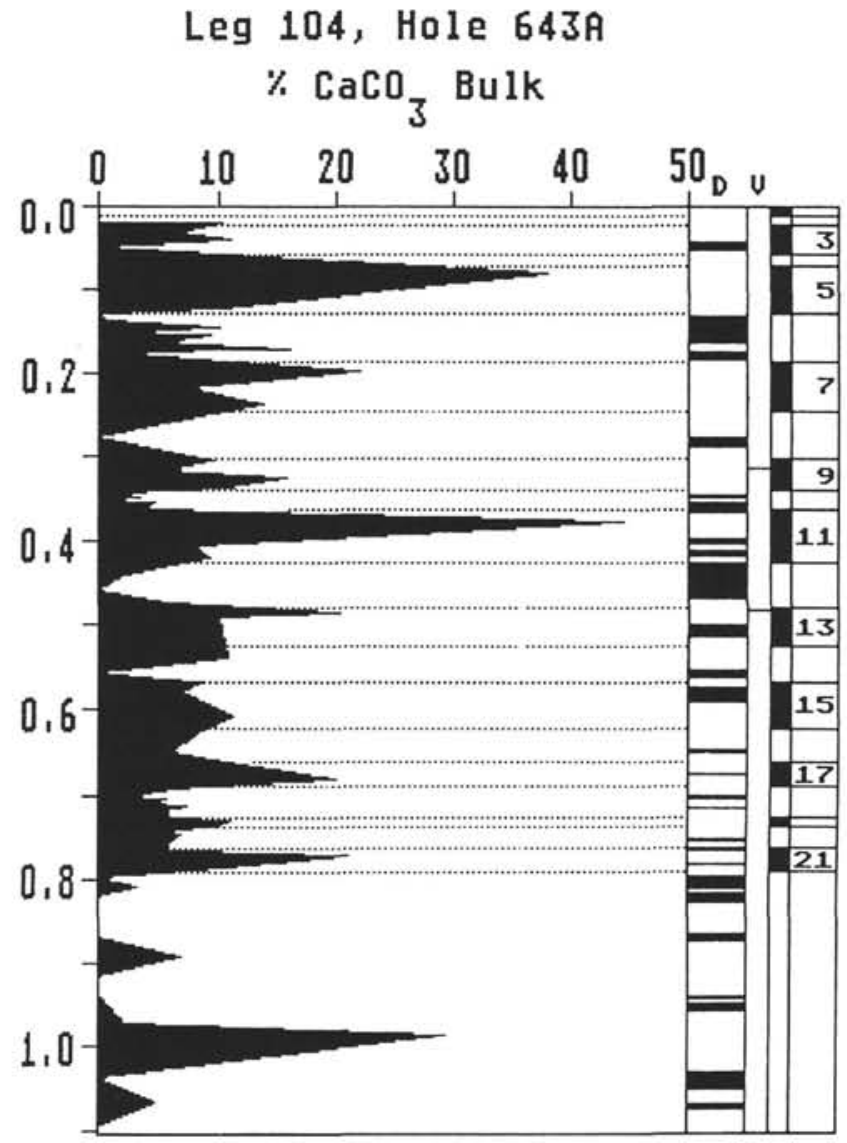

Figure 4. Carbonate/oxygen isotope stratigraphy of Holes $642 \mathrm{~B}$ and $643 \mathrm{~A}$ during the last $1 \mathrm{Ma}(\mathrm{D}=$ dark lithofacies occurrences, $\mathrm{V}=$ position of volcanic ash beds).

glacial stages in the Norwegian-Greenland Sea (Belanger and Streeter, 1982; Osterman, unpublished data). Hence, stage boundaries in the section from $15 \mathrm{mbsf}$ to $23 \mathrm{mbsf}$ in Hole $643 \mathrm{~A}$ were established by carbonate stratigraphy. The light oxygen isotope values meassured on planktonic foraminifers might be interpreted as effects attained in a low-salinity surface-water layer.

Nevertheless, because no other additional stratigraphic control is available, we feel the proposed stratigraphic framework is the best time scale yet provided. Linear sedimentation rates (LSR) were calculated using the combined carbonate/oxygen isotope stratigraphy. Bulk accumulation rates and accumulation rates for various other sedimentological parameters were determined based on the method of Ehrmann and Thiede (1985).

\section{RESULTS}

\section{Glacial and Interglacial Lithofacies Types}

The most prominent features of glacial/interglacial cycles in the Norwegian Sea are the pronounced changes between light and dark sediment layers. They appear on two scales: a largescale in the meter range and a smaller scale ranging from centimeters to tens of centimeters (Eldholm, Thiede, Taylor, et al., 1987; Henrich et al., unpublished data). Although the exact color tint changes downcore, with minor brownish colors in the light layers, they alternate consistently, indicating repeated complex cycles in sedimentation.

Light layers usually are thicker than dark layers and display three major lithofacies types:

\section{Facies $A$}

This facies consists of predominantly brownish to dark brownish, minor light olive-gray to olive-gray foraminifer muds and foraminifer-nannofossil oozes with high carbonate (30-60\%) and foraminifer (30-40\%) contents and small amounts of organic carbon $(0.1-0.3 \%)$ and coarse terrigenous debris (mostly less than 5\%). Indistinct and well-developed burrows are the most commonly observed sedimentary structures. The variety of bioturbation features includes: centimeter-sized burrow tubes of the planolites type, millimeter-sized and up to 20-cm-long vertical tubes as well as a close network of thin-banded tube burrows of the genera Mycellia sensu Blampeded \& Bellaiche.

\section{Facies $\boldsymbol{B}$}

This facies consists of silty muds and sandy muds of the same colors and bioturbation features as facies $\mathrm{A}$, but with lower carbonate $(1-10 \%)$ and foraminifer contents $(1-10 \%)$ and low- to moderate organic carbon values $(0.2-0.3 \%)$. Proportions of coarse terrigenous material are enriched, often within separated layers. Occasional coarse lithic dropstones and some dark olive-gray mudclasts are observed.

\section{Facies $C$}

This facies consists of gray to dark-gray silty muds, with low carbonate $(1-5 \%$, seldom up to $10 \%)$ and foraminifer contents $(1-5 \%)$, moderate organic carbon contents $(0.2-0.4 \%)$, moderate amounts of coarse sand-sized terrigenous debris $(5-10 \%)$, scattered dropstones and few mud clasts. Distinct bioturbation features as in facies A may be present, but without thorough ho- 
mogenization of the sediment. Facies $\mathrm{C}$ forms the normal background sediment in the color cycles on the large scale where thick beds of facies $\mathrm{C}$ alternate with thin horizons of facies $\mathrm{A}$ and $\mathrm{B}$.

Three major types of dark lithofacies are intercalated in these light sediment packages:

\section{Facies D}

This facies consists of very dark-gray to black, sandy to silty muds with very low contents of carbonate $(0-0.3 \%)$ and foraminifers (sometimes less than 50 tests in the entire sample) and high percentages of organic carbon $(0.5-1.2 \%)$. Commonly these layers contain very high amounts of sand-sized terrigenous debris $(20-30 \%)$, as well as densely scattered dropstones and abundant mud clasts. Due to absence of bioturbation these horizons are characterized by a sharp base and top.

\section{Facies $\boldsymbol{E}$}

This facies is composed of dark olive-gray sandy muds with very low carbonate $(0-0.3 \%)$ and foraminifer contents (sometimes less than 50 tests in the entire sample), high organic carbon contents $(0.5-1.2 \%)$ and densely scattered dropstones and abundant mud clasts. These layers commonly show a sharp top and base but sometimes the top and base contacts may be blurred by bioturbation.

\section{Facies $\boldsymbol{F}$}

This facies forms a complex layer consisting of a basal very dark-gray to black sandy mud with numerous scattered dropstones and common large mud clasts. It grades upward into a dark olive-gray sandy mud with abundant dropstones and mud clasts. The entire package is very low in carbonate $(0-0.3 \%)$, sometimes completely carbonate-free, but high in organic carbon $(0.5-1.2 \%)$. In higher parts of sections with F-facies, sedimentary structures, especially the mud clasts, may be truncated by brownish iron laminations, spaced at millimeter to centimeter levels (Fig. 5). These diagenetic laminations in turn may be truncated by younger burrows filled with sediment from above. The laminated horizons reveal a remarkably higher degree of consolidation and lithification compared to the sediments above and below (Kassens and Sarnthein, unpublished data). In most cases, facies $\mathrm{F}$ is succeeded by sediments of lithofacies B, occasionally by lithofacies C. An illustration of lithofacies $\mathrm{F}$ in a radiograph is displayed in Fig. 5.

Lithofacies A was deposited during interglacials, while facies $C$ records the sedimentary environment of glacial periods. Sediments of type B accumulated during early and late interglacial periods as well as during glacial periods. Lithofacies D, E, and F consist of late glacial/early deglaciation sediments either deposited during the major transitions from a glacial to an interglacial stage or within a glacial period indicating a very specific oceanographic configuration.

\section{STRATIGRAPHY AND SEDIMENTOLOGY}

The combined carbonate and oxygen isotope stratigraphic records of Holes 642 and 643 are displayed in Figure 4. The data base is documented in Tables A1, A2, and A3 in the Appendix. The most obvious feature is the almost complete loss of carbonate between $1 \mathrm{Ma}$ and 1.2 Ma. The highest carbonate contents were deposited during stages 5, 11, and 21 at both sites; stage 11 reflecting the maximum in carbonate content. Lower and less consistant contents are indicated for stages $7,9,13,15,17$, and 19. Generally, carbonate contents at Site 642 on the Vøring Plateau are lower than those at Site 643 on the Lofoten Slope.

The basic sedimentological features of both sites, e.g., the occurrence of dark lithofacies D, E, and F and oxygen isotope-,

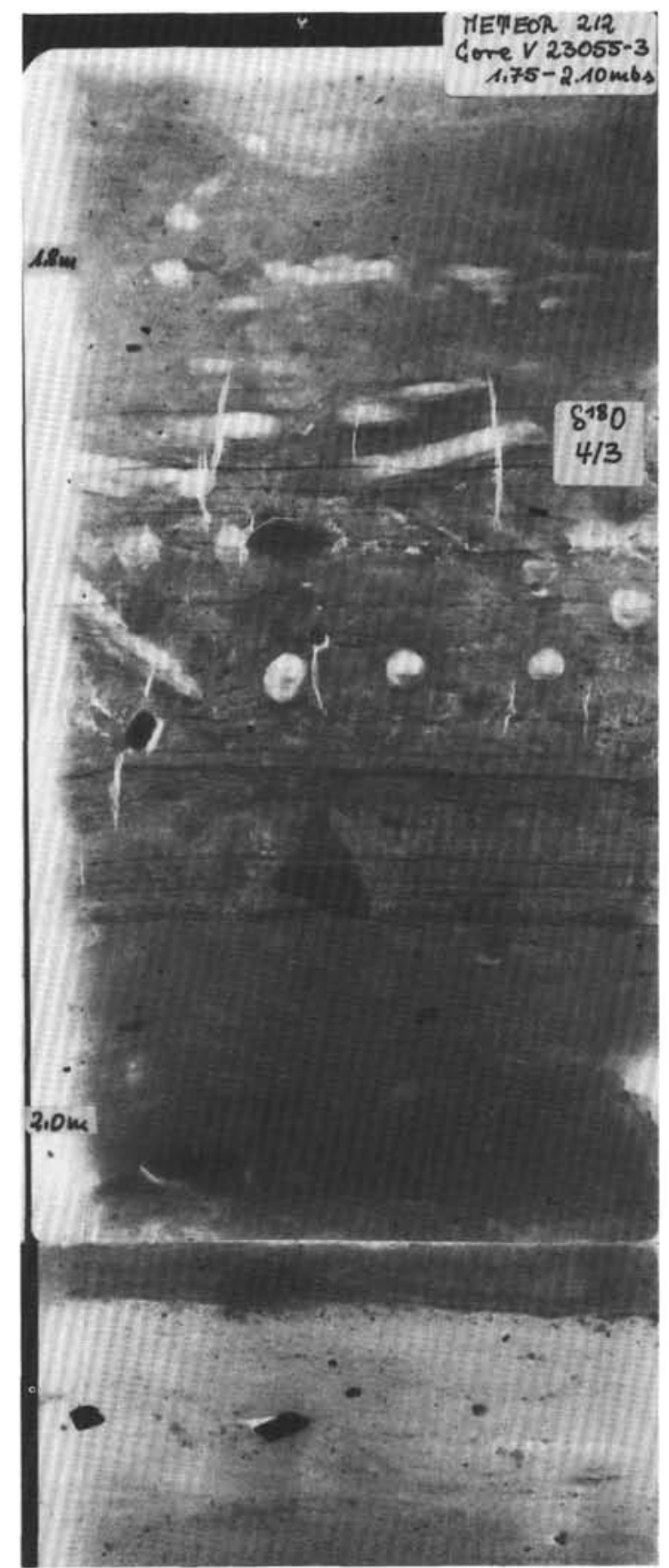

Figure 5. Radiograph of lithofacies type $\mathrm{F}$ (complex diamicton). Note enrichment of coarse lithic (1), mud dropstones (2), early diagenetic iron lamination (3), and younger oxic burrow fillings (4); kasten core GIK 23055-3, northern Vøring Plateau.

carbonate-, organic carbon- and SEM-dissolution records are compiled in Figs. 6, 7, and 8. A rhythmic alternation of dark (marked by dark bands in Figs. 6, 7, and 8) and light lithofacies is the most notable pattern in the interval characterized by glacial/interglacial cycles (Eldholm, Thiede, Taylor, et al., 1987). Carbonate cyclicity is indicated only for the upper sediment sections younger than 1.2 Ma at Site 642 and 643, while cyclic fluctuations in organic carbon occur throughout lithologic Unit I. At Site 644 carbonate is present throughout the section with glacial/interglacial cycles (Fig. 8). Below $110 \mathrm{mbsf}$ a drastic decrease in carbonate values is observed. This level corresponds to 

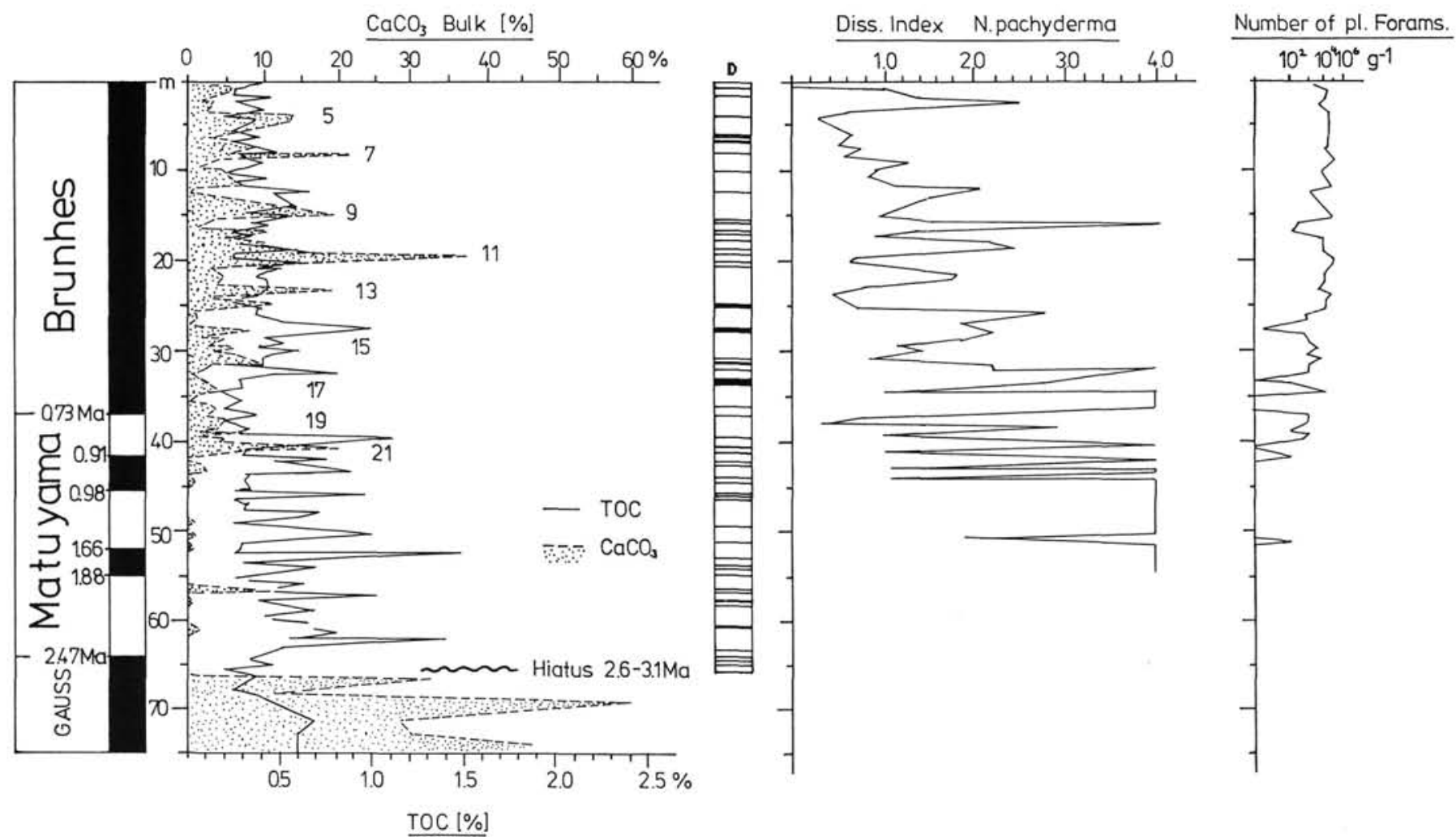

Figure 6. Carbonate, organic carbon, and dissolution records, and dark layers (D) in Hole 642B. Note exact correlation of low carbonate values with dark lithofacies occurrences, high organic carbon contents (TOC), and dissolution peaks. Below 32 mbsf an overall strong increase in dissolution corresponds to the almost complete loss of carbonate.

an age of about 1.2 Ma. Dissolution peaks are strictly confined to the dark lithofacies D, E, and F during stages 2 to 11 (Figs. 6, 7). An overall increase in dissolution is recorded below stage 11, resulting in the almost complete loss of carbonate prior to 1.2 $\mathrm{Ma}$ at Sites 642 and 643 . The few foraminifers in the almost carbonate-free section below reveal very strong corrosion (Figs. 6, 7).

\section{THE LONG-TERM RECORD OF ICE RAFTING AND CARBONATE SHELL PRODUCTION}

Results from the coarse-fraction countings plotted vs. subbottom depths as well as vs. ages are compiled in Figures 9-14. The cyclic fluctuations in particle composition are best seen in the sum diagram of the coarse-fraction composition in Hole 642B (Fig. 9) showing repeated alternations of biogenic calcareous dominated particle associations (e.g. in planktonic and benthonic foraminifers), and terrigenous-dominated particle assemblages. Immaturity of the terrigenous-dominated particle assemblages is documented by high amounts of rock fragments, feldspar, mica, and rounded quartz. Rock fragments consist of various igneous and metamorphic lithologies as well as specific sediments. Most interesting with respect to provenance are whitish chalk fragments. In the same horizons Cretaceous and Tertiary foraminifers were found (Spiegler, this volume). Concerning bedrock sources for the chalks, shallow outcrops, and subcrops below a thin Quaternary cover parallel to the Norwegian coastal shelf (Rokoengen et al., 1980; Rokoengen and Sattem, 1983; Hald and Vorren, 1987) or the North Sea and adjacent continental areas in southern Scandinavia and Great Britain (Wohlfeil, 1982, 1983) have to be considered. Grain-size plots
(Fig. 10) reveal a very bad sorting in the horizons with peak inputs of terrigenous coarse fraction. The cyclic input of coarse ice-rafted debris is well documented by the fluctuations of the $>500-\mu \mathrm{m}$ subfraction. Rounded quartz that was detected in minor proportion in the glacial sediments (Fig. 9) is thought to be derived from reworked Mesozoic rocks on the shelf. Peak inputs of ice-rafted debris, as indicated by increases in the contents of quartz, feldspar, and rock fragments, predominantely occur in the dark lithofacies D, E, and F (marked by dark barks in Figs. $11,12)$. These extraordinary high concentrations of ice-rafted components are preferentially found below and above the oxygen isotope transitions. In addition, higher but episodic inputs are observed within various glacial stages, especially throughout stages 6,10 , and 12 (Figs. 11,12). Stage 7 at both sites and stage 15 at Site 642 reveal two to three peaks of planktonic foraminifers interrupted by ice-rafted debris-rich sediment packages (Figs. $11,12)$. This pattern suggests that interglacial periods were interrupted by cooling events causing an advance of the continental ice that was disintegrated during the next warming.

Calcareous, biogenic particle-dominated associations are restricted to the last 1- to 1.2-Ma interglacial stages (Fig. 11, 12). Prior to $1.2 \mathrm{Ma}$ calcareous particles are only found in trace amounts at Sites 642 and 643; but terrigenous particles still reveal repeated alternation in sorting and maturity throughout the past $2.56 \mathrm{Ma}$, indicating the persistance of episodic inputs of ice-rafted debris (Figs. 13, 14). Planktonic foraminifers account for a considerable portion of the sand fraction at Sites 642 and 643 during the last 500 to 600 k.y. (Figs. 11, 12). These amounts diminish remarkably prior to $500 \mathrm{k}$.y., where an increase in dissolution is also recorded (Figs. 6, 7). Planktonic foraminifer peaks in the sand fraction predominantely occur in interglacial 


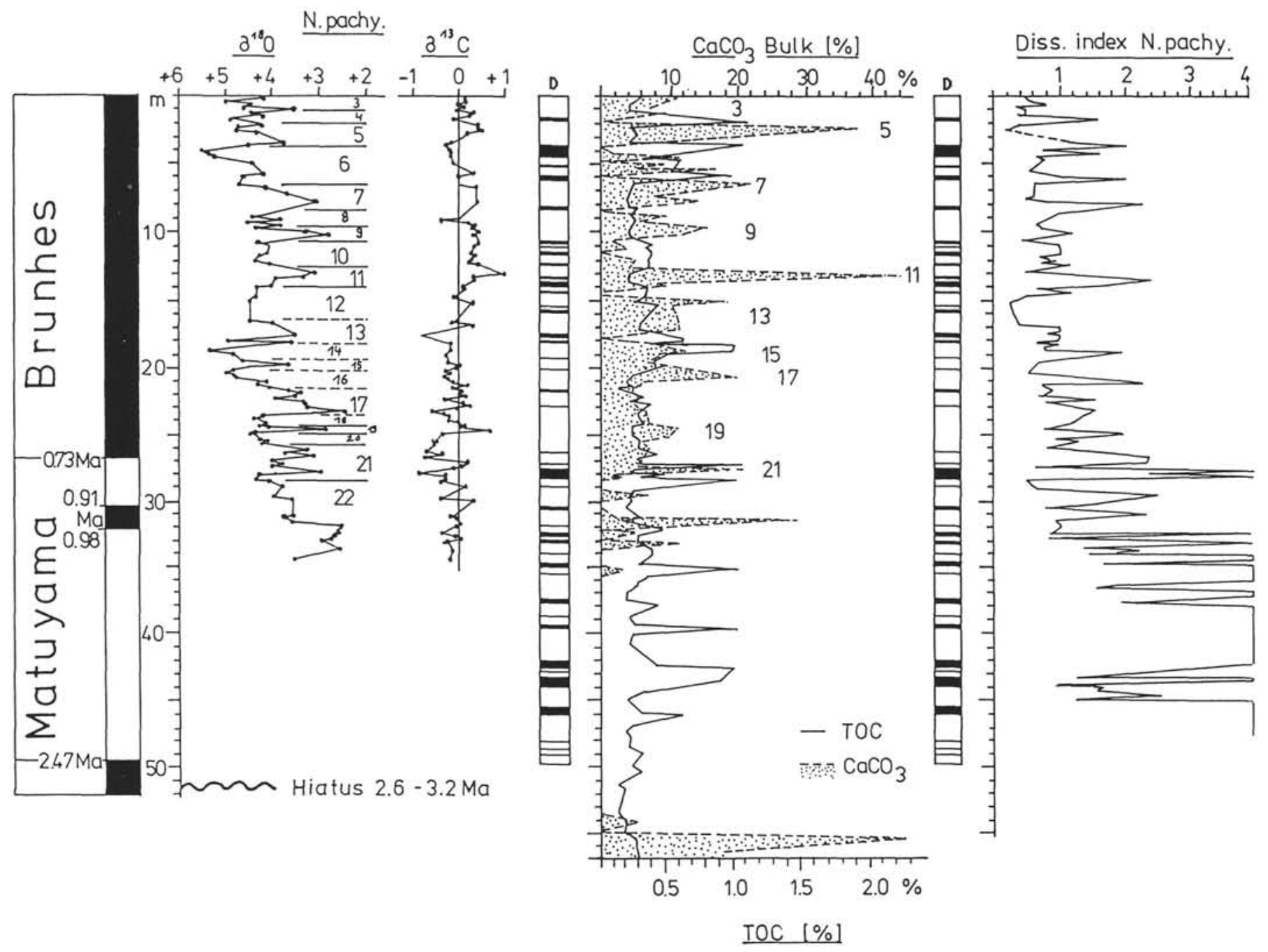

Figure 7. Carbonate, organic carbon, and dissolution records and dark layers in Hole 643A. Note exact correlation of low carbonate values with dark lithofacies occurrences, high organic carbon contents (TOC), and dissolution peaks. Below 25 mbsf overall strong increase in dissolution corresponds to the almost complete loss of carbonate. Inconsistencies in establishing exact stage boundaries in carbonate and oxygen isotope records are evident in the interval from 15 to 23 mbsf (compare discussion in chapter on stratigraphic methods).

sediments, and only subordinately during long glacial intervals when only minor ice rafting affected the sediment compositions.

\section{VARIABILITY OF SEDIMENTATION AND BULK ACCUMULATION RATES}

Linear sedimentation rates (LSR) for all three sites of Leg 104 are listed in Table 2. The most prominent trend is a drastic increase of LSR toward the shelf, with lowest rates at Site 643, intermediate rates at Site 642 , and highest rates at Site 644. The second trend is a general downcore decrease of LSR at all three sites, observed as a sudden drop of LSR at Sites 642 and 643 and by a more stepwise decrease at Site 644 . These trends clearly document an offshore decrease in sediment deposition derived from continental sources.

A comparison of Site 643 and 642 sections deposited during the last 800 k.y. shows a trend towards higher LSR during the odd-numbered isotope stages (Table 2). The lowest rates at both sites are recorded during stages with highest carbonate contents, e.g., stages 5, 11, and 21. Additionally, stage 8 also contains a very low LSR at both sites. On the other hand, extraordinarily high rates are indicated at both sites for stages $6,9,10$, and 18 to 20 and intermediate values for stages 13 and 14 . Stage 7,12 , 15 , and 16 show intermediate to high LSR at Site 642 but a low LSR at Site 643. Intermediate to high LSR are found in low carbonate sediments that are high in terrigenous contents.

Major long-term variations of terrigenous inputs are evident in the drill sites. Increased inputs are reflected from stage 20 to 18 and in stages 10 and 6. Prior to $1.2 \mathrm{Ma}$ a drastic decrease in LSR is observed in all sites (Table 2). This pattern indicates a major change in overall sediment supply. Sites 642 and 643 bulk accumulation rates $\left(\mathrm{AR}_{\text {Bulk }}\right.$, compare Figs. 16-19) confirm the trends already seen in the sedimentation rates. Accumulation rates at Site 642 are generally higher than those of Site 643 . Exceptionally high rates are reflected during stages $6,9,10$, and 18 to 20 , while very low rates are recorded during stages 5,11 , and 21 in both sites (Figs. 16, 17). Variable rates with a tendency toward higher rates in Hole 642B are indicated in stages 7, 8, and 12 to 16. A drastic decrease in $\mathrm{AR}_{\text {Bulk }}$ is observed prior to 1.2 Ma (Figs. 18, 19).

This spatial and temporal distribution pattern of LSR can be attributed to variations in the two most important sediment sources in the Norwegian Sea, that is, carbonate productivity of 

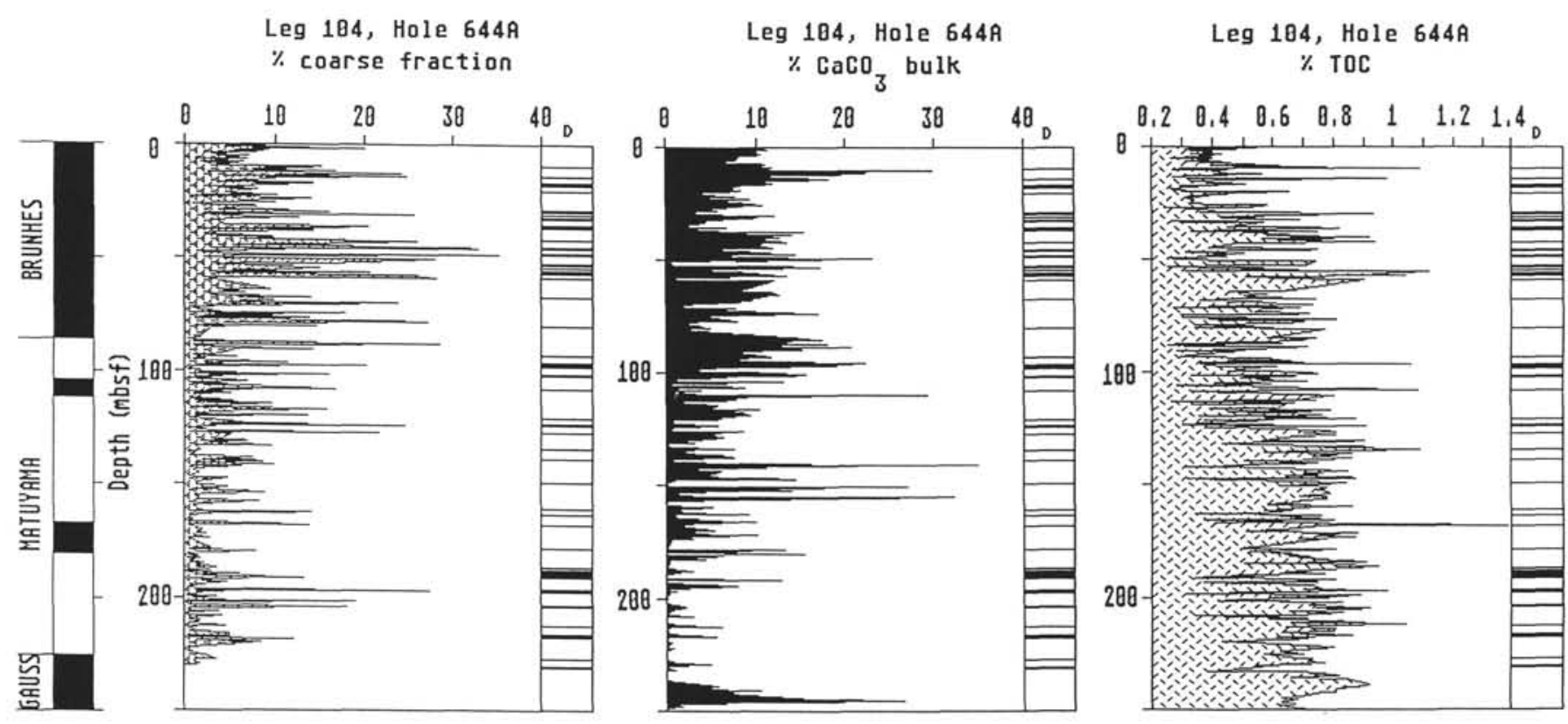

Figure 8. Carbonate carbon, organic carbon, and coarse-fraction contents and dark layers (D) in Hole 644A. Note consistency of organic carbon and coarse-fraction peaks with dark lithofacies occurrences.

the Norwegian Current and input of ice-rafted and resuspended debris into the deep sea, derived from continental sources over Scandinavia. In general, when carbonate productivity is highest, e.g., during the warmest interglacials with high sea level, offshore the supply of sediment is mainly limited to the pelagic rain from the Norwegian Current. Low LSR occurs at this time, because terrigenous material is mostly stored on the continental shelf. Maximum inputs of ice-rafted and resuspended debris occur in glacial and deglacial periods, when sea level is low or rising, and terrigenous material is transported into the deep sea.

The long-term record of carbonate-organic carbon accumulation and carbonate dissolution in Holes 642B and 643A bulk accumulation rates (AR bulk) at Sites 642 and 643 (Figs. 16, 17) roughly reflect two $400-\mathrm{k} . \mathrm{y}$. trends superimposed on a $100-\mathrm{k}$.y. signal. AR bulk at Site 643 suggests that pairs of two 100-k.y. cycles make up the $400-k . y$. signal. Bulk sediment input is largest at the beginning of each $400-\mathrm{k}$.y. period. A similar signal may be recorded in the bulk carbonate accumulation rate of Site 643 , but is less evident at Site 642 (Figs. 16, 17). Organic carbon accumulation rates at both sites also show this $400-\mathrm{k}$.y. signal, as well as two pairs of 100-k.y. subsignals. High carbonate accumulation rates occur at both sites during isotope stages $7,9,11$, 13 , and 17 to 21 (Figs. 16, 17). Stage 5 is better developed in Hole 643A (Fig. 17) than in Hole 642B (Fig. 16). Low bulk carbonate accumulation rates are indicated in stages $8,10,12,14$, and 16 at both sites (Fig. 16, 17). Stage 6 has strongly fluctuating bulk carbonate inputs, especially in Hole 643A (Fig. 17).

Two obvious features of sites 642 and 643 carbonate records are (Figs. 20, 21): All changes in accumulation rates affect coarse, fine, and bulk carbonate in the same way, and the overall magnitude in carbonate flux is of about the same range at both sites. The total flux of carbonate during the last $600 \mathrm{k}$.y. was larger than during the interval 0.6 to $1.2 \mathrm{Ma}$. Stage $11 \mathrm{re}-$ veals the highest carbonate flux observed throughout the last 1.2 Ma. In detail, there are significant variations in carbonate fluxes and composition during the last 1.2 Ma. Coarse-fraction carbonate can be considered in a first approximation to reflect planktonic foraminifer shell production in surface waters, while fine carbonate fluxes can be used to quantify the supply of nannofossils. Applying this assumption, foraminifer-dominated carbonate fluxes were only observed during isotope stages 5,6 , and 7 at Site 643 (Fig. 21). Equivalent amounts of foraminifers and nannofossils were deposited during stages 5, 7, 9, and 13 at Site 642 (Fig. 20), and stages 9 and 13 at Site 643 (Fig. 21). Stages 8, 10,11 , and 14 to 21 reveal a clear excess of fine-fraction carbonate. This pattern is not easy to interpret. Because today a high calcareous nannoplankton production is restricted to the warm Atlantic water, increased resuspension processes possibly derived from fossil carbonates, e.g., Cretaceous to Tertiary chalks (Spiegler, this volume), are the most probable explanation for the high proportions of fine-fraction carbonate in the glacial fluxes.

The variations in carbonate fluxes confirm the results of the dissolution records displayed in Figures 6 and 7. During the last 500 k.y. episodic strong dissolution events were found to be strictly confined to the late glacial/early deglacial periods, while a long-term dissolution increase is indicated prior to 500 to 600 k.y. Prior to $1.2 \mathrm{Ma}$ the almost complete loss of carbonate at Sites 642 and 643 (Figs. 18, 19) can be, at least partly, attributed to overall strong dissolution, but may also indicate a drastic decrease in carbonate productivity in surface waters.

Organic carbon accumulation rates are generally high in oddnumbered isotope stages at Sites 642 and Site 643 (Figs. 16, 17). Accumulation peaks at both sites occur at the transition stage $4 / 3$, and during isotope stages 6 (best developed at Site 643), 10, 18 , and 20 . Additionally, Hole $642 \mathrm{~B}$ records a higher accumulation of organic carbon during stages $4,7,9$, upper part of 11 , and 14 to 16 (Fig. 16).

High accumulation rates of organic carbon coincide with increased inputs of ice-rafted debris (compare Figs. 11 and 16, 12 and 17); evidence of a causal relationship between these two parameters. An increase in the rate of resuspension of terrigenous and shelf-derived organic matter during lowered sea levels and ice rafting of shelf sediments rich in organic matter are thought to represent the most important sources of organic material. Preliminary analysis of the composition of the organic matter 


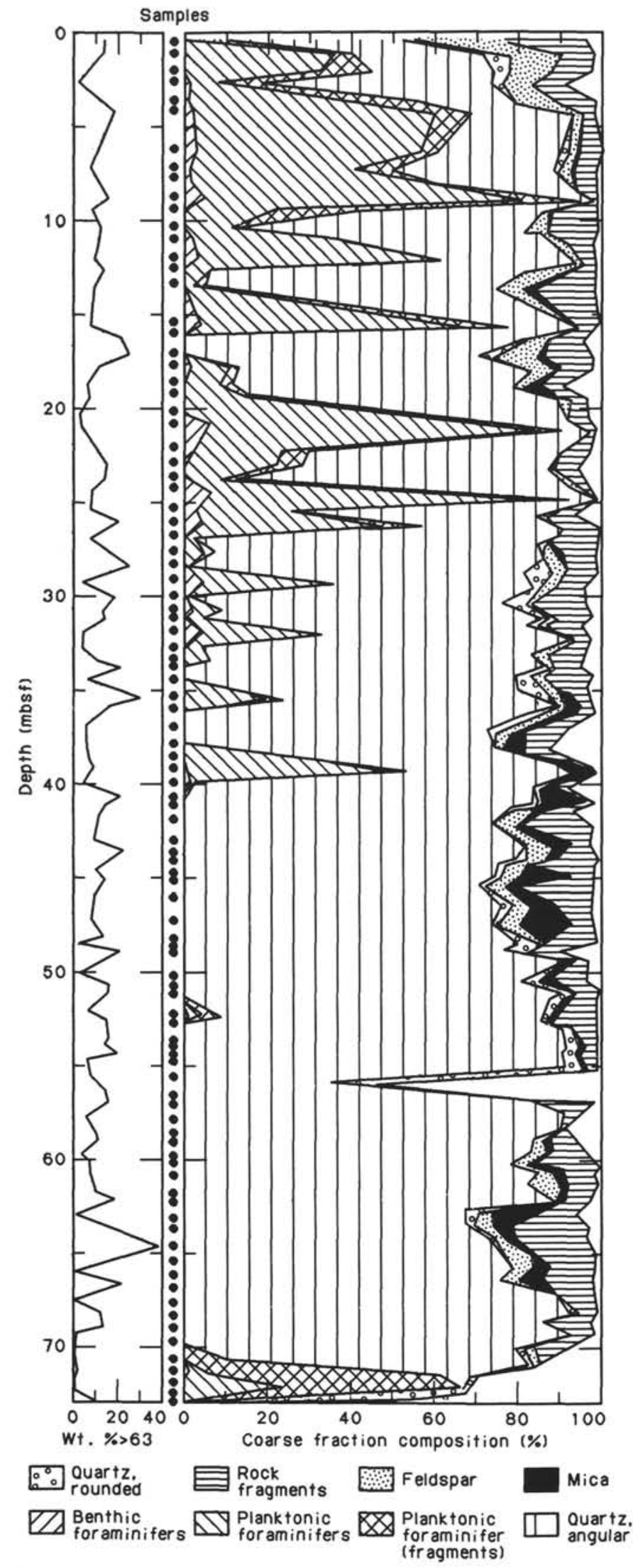

Figure 9. Coarse-fraction composition in Hole 642B (sum diagram) revealing repeated alternations of biogenic calcareous and terrigenous coarse-particle assemblages. indicates predominance of terrigenous sources, which supports the above proposition (compare organic geochemistry chapters in Eldholm, Thiede, Taylor, et al., 1987; Henrich et al. in press).

\section{GLACIAL AND DEGLACIAL SEDIMENTS: SEDIMENTOLOGICAL FEATURES AND PALEOENVIRONMENTAL SIGNIFICANCE}

Regional and temporal distribution of lithofacies in the Leg 104 drill sites reveal typical successions of facies by which major changes in surface- and bottom-water circulation are reflected. Typical facies patterns in the Leg 104 drill sites, supplemented by additional data from a transect of long kasten cores from the Vøring Plateau toward Jan Mayen (Henrich et al., in press), were analysed and interpreted in a conceptual paleoceanographic model. The most prominent and most obvious feature of facies patterns are occurrences of the specific dark lithofacies F, D, and E marked on all figures with dark barks. A number of unique sedimentological features appear to be characteristic of the dark lithofacies. Most horizons conicide with maximum concentrations of ice-rafted debris, e.g., peaks in quartz-, feldspar-, and rock-fragment contents (Figs. 11, 12), very low carbonate-, high organic-carbon contents, and with dissolution peaks (Figs. 6, 7). They commonly reveal only traces of planktonic foraminifers and coincide with sections barren in benthonic foraminifers (Figs. 11, 12).

Typical lithofacies successions in the ODP Leg 104 drill sites have been summarized in Fig. 22. The succession of lithofacies most commonly observed at the transitions from a glacial to a well-developed interglacial stage is as follows: Glacial lithofacies $\mathrm{C}$ is overlain by late glacial/early deglaciation lithofacies $\mathrm{F}$ and the interglacial lithofacies B and A (Fig. 22a). At the base of lithofacies $\mathrm{F}$ a sudden and drastic increase in input of ice-rafted debris is observed. Frequently, large dropstones and several cmsized soft mud clasts, which are interpreted as mud-dropstones, appear. At the same level a sudden increase in carbonate dissolution recorded by SEM-dissolution indexes (Figs. 6, 7) and a pronounced change in the redox potential of the sediments toward anoxic conditions occurs. The change in redox potential occured during incipient burial of sediments. The very low content of the planktonic fauna and flora in these late glacial/early deglaciation sediments cannot be explained just by high dissolution at the sea floor, but is also a result of a drastic decrease in surface-water productivity, possibly due to high meltwater inputs associated with increased production or rafting of icebergs or sea ice. Indications are sparse, but the predominance of very small tests in the relict planktonic foraminifer associations may support the assumption. Most features in the topmost section of lithofacies F, e.g., the change in color to dark olive-grey and the iron laminations, are caused by early diagenetic overprinting of sediment similar to the basal lithofacies. Ice rafting in surface water and carbonate dissolution at the sea floor is recorded in lithofacies B but gradually decreases upward, while carbonate productivity increases. Lithofacies A at the top of the entire cycle records a normal interglacial situation with high carbonate productivity and a good carbonate preservation at the sea floor. The entire sequence clearly records sudden changes in surfaceand deep-water conditions.

Such a complete succession of lithofacies mostly is recorded below the transitions of isotope stages $6 / 5,10 / 9,12 / 11$, and 18/17 (Figs. 11, 12). Evidence from the long box cores (Henrich et al., in press) reveals that the transition in the oxygen isotope records is consistently observed just a few centimeters above facies $\mathrm{F}$ and occurs in sediments of facies B. Furthermore, occurrences of facies F, D, and E are not only restricted to the transitions from glacial to interglacial stages but frequently are developed within glacial stages (Figs. 11, 12). The features of 
Hole 642 B

\section{cumulative weight percentages}

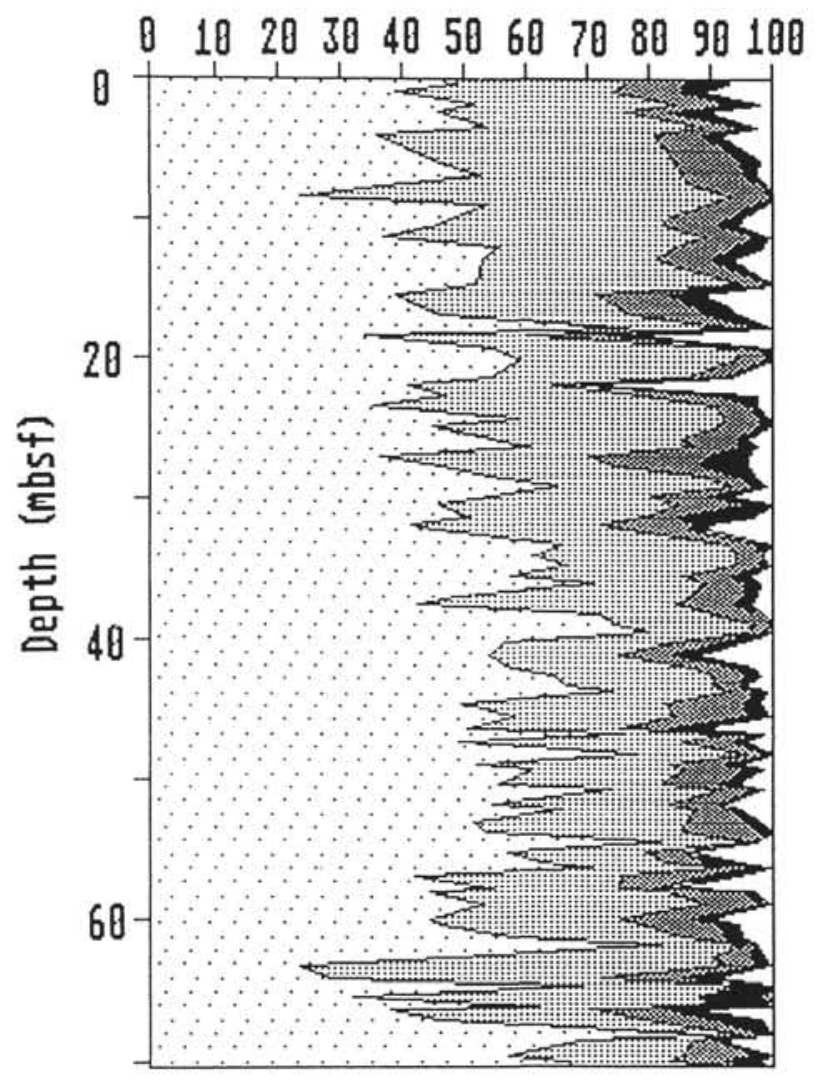

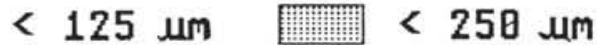

Hole 643 A

\section{cumulative weight percentages}

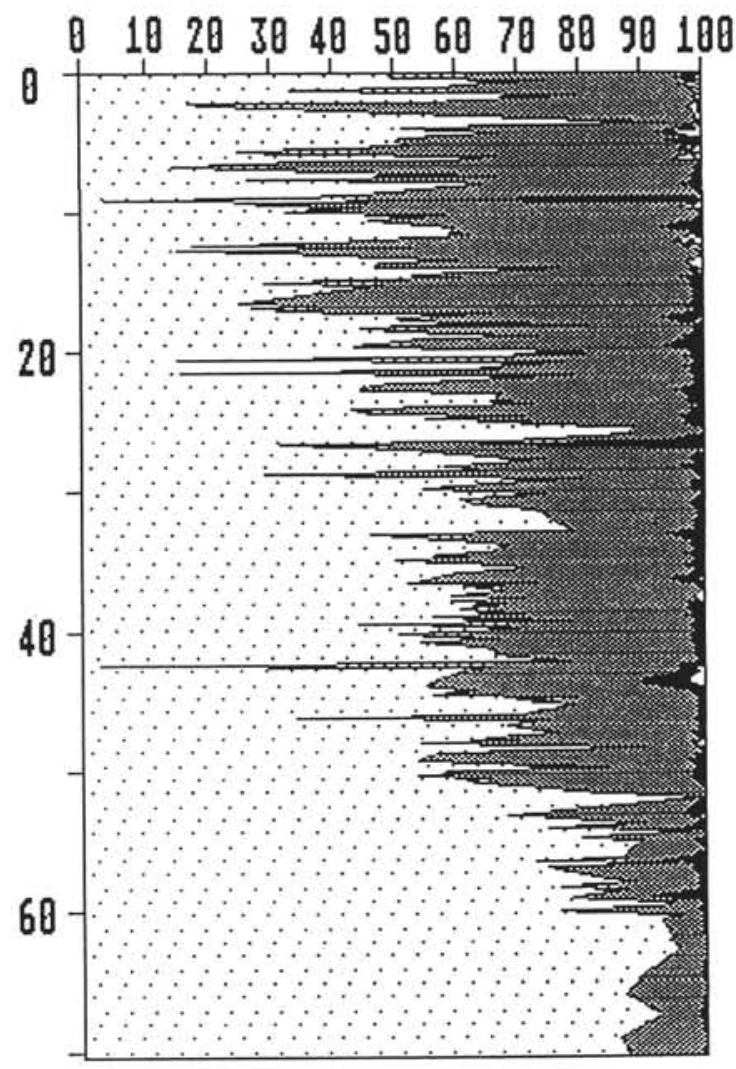

$<580$ um

Figure 10. Grain-size analyses, Holes 642B and 643A. Note cyclic input of coarse ice-rafted debris indicated by sections with peaks of size fractions above $500 \mu \mathrm{m}$.

sedimentological response to these minor deglaciations are compiled in Fig. 22b. The principal configuration is an intercalation of facies $\mathrm{D}, \mathrm{E}$, and $\mathrm{F}$ within facies $\mathrm{C}$. The main difference is the absence of facies A on top of the sequence indicating that deglaciation was not capable of initiating carbonate productivity and establishing complete oxygenation of bottom waters.

Further evidence from the long box cores (Henrich et al., in press) indicates that some of these horizons, e.g., those at the transitions $6 / 5,10 / 9$, and within lowermost 6 can be traced from the Vøring Plateau far offshore to the west, where most of them (e.g., the horizons at $6 / 5$ and in lowermost 6 ) grade into a sediment layer of lithofacies type B (e.g., a brownish sandy mud with scattered dropstones) that is extremely enriched with coarse lithic dropstones.

\section{PALEOCEANOGRAPHIC MODEL AND EARLY DIAGENESIS OF GLACIAL AND LATE GLACIAL/EARLY DEGLACIAL SEDIMENTS}

All sedimentological and early diagenetic observations have been integrated in a conceptual model describing stepwise changes in bottom and surface-water circulation during the transition from glacial conditions to a full interglacial environment. The pro- posed paleoceanographic settings were illustrated in schematic block diagrams (Fig. 23). The situation recorded in lithofacies type $\mathrm{C}$ represents the period of strong glaciation, indicated in the sediments by low contents of ice-rafted debris and a reduced carbonate productivity (Fig. 23A). During this period the Scandinavian continental ice shield progressed onto the Norwegian shelf. During severe glaciation the continental ice sheets extended toward and below the shelf edge. King et al. (1987) present maps showing till tongue distribution patterns on the mid Norwegian shelf based on seismic interpretations. The deepest till tongue occurrences were found close to the shelf edge at water depths below 400 to $600 \mathrm{~m}$. Large amounts of shelf sediments have been incorporated into the basal parts of glacier ice during advance. Offshore sea-ice cover most likely fluctuated between a complete cover during winter and summer pack ice interspersed with drifting icebergs. During this period, vertical mixing of ocean water was depressed, possibly resulting in oxygen-depleted bottom-water conditions.

During maximum advance of continental ice onto the Norwegian shelf, large-scale calving of icebergs most probably induced by surges along the ice front contributed huge amounts of icebergs into the southern sector of the Norwegian Sea (Fig. 


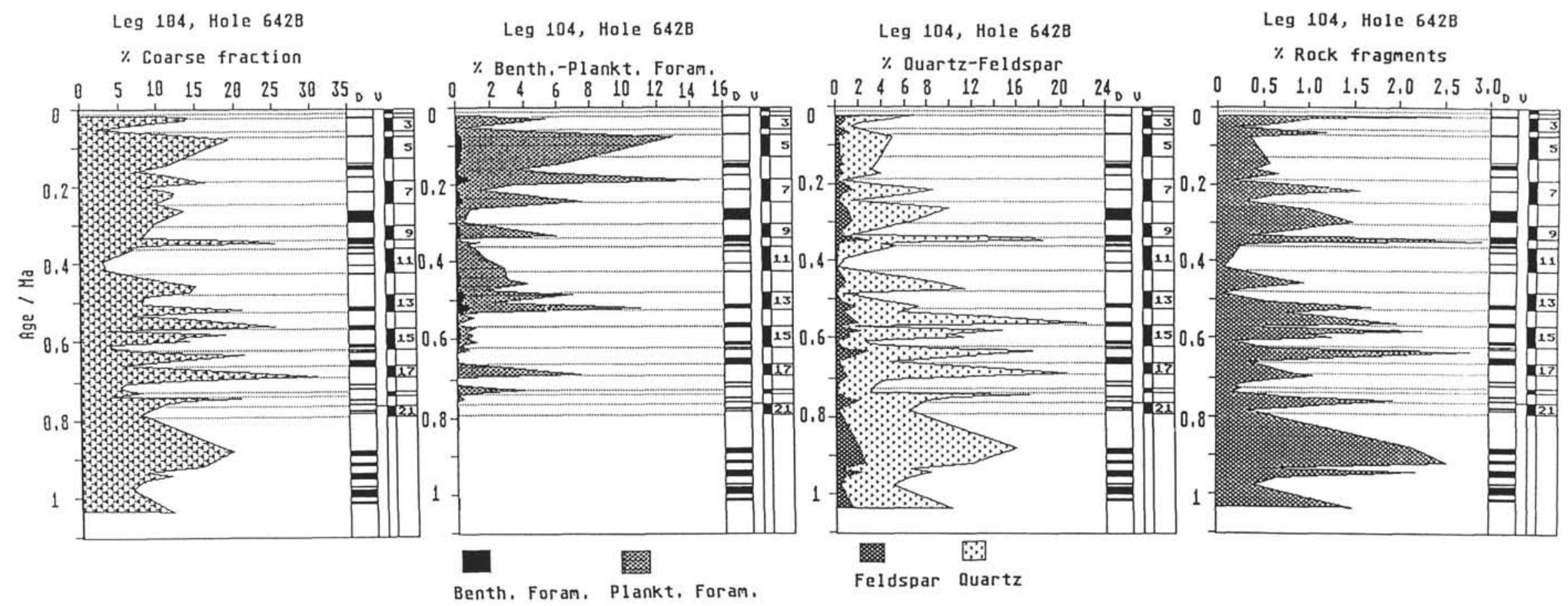

Figure 11. Parameters of carbonate productivity and cyclicity in inputs of ice-rafted debris during the last $1 \mathrm{~m} . \mathrm{y}$. seen in the coarse-fraction composition of Hole $642 \mathrm{~B}(\mathrm{D}=$ dark lithofacies, $\mathrm{V}=$ volcanic ash beds). Interglacial stages reveal planktonic and benthic foraminifer-dominated particle associations, while glacial stages contain terrigenous particle associations. Note strong correlation of peak concentrations in quartz, feldspar, and rock fragments with dark lithofacies occurrences. All values are expressed as weight percentages on bulk sediment. 


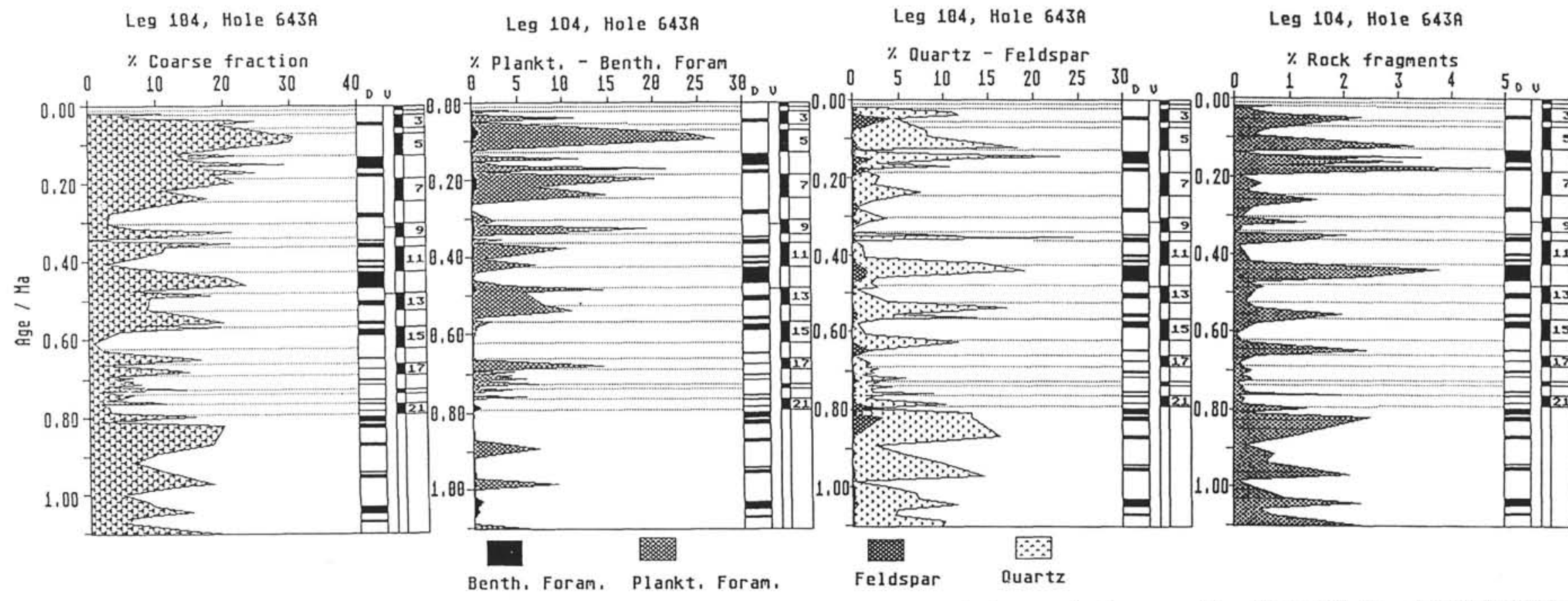

Figure 12. Parameters of carbonate productivity and cyclicity in inputs of ice-rafted debris during the last $1 \mathrm{~m} . \mathrm{y}$. seen in the coarse-fraction composition of Hole $643 \mathrm{~A}$ (D $=$ dark lithofacies, $\mathrm{V}=$ volcanic ash beds). Interglacial stages reveal planktonic and benthic foraminifer-dominated particle associations, while glacial stages contain terrigenous particle associations. Note strong correlation of peak concentrations in quartz, feldspar, and rock fragments with dark lithofacies occurrences. All values are expressed as weight percentages on bulk sediment. 


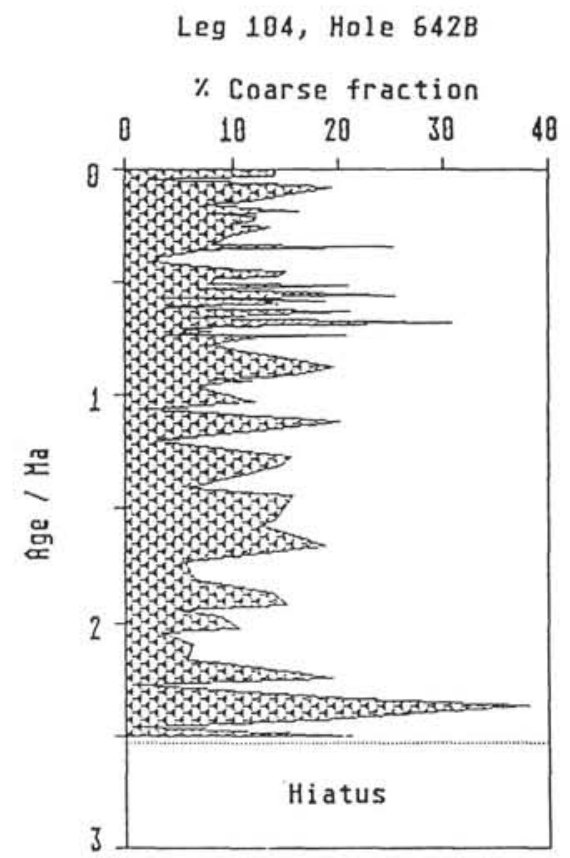

Leg 184, Hole 642B

\% Benth, -plankt. Foram.

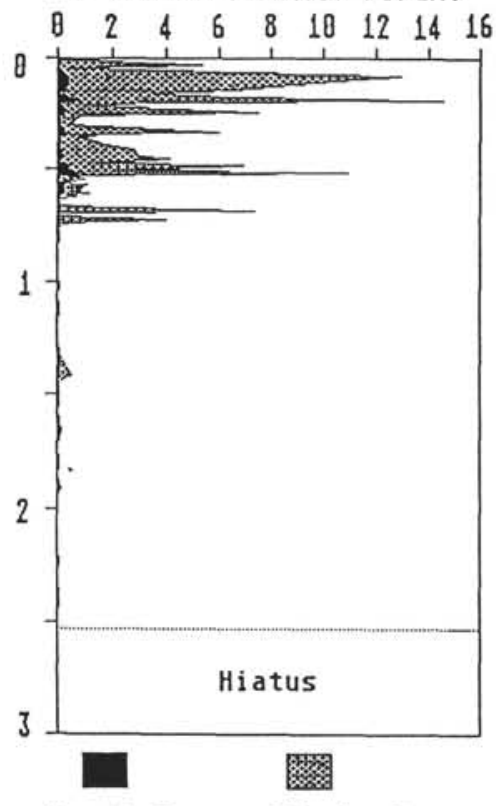

Benth, Foram, Plankt, Foram.
Leg 104, Hole 642B

\% Duartz-Feldspar

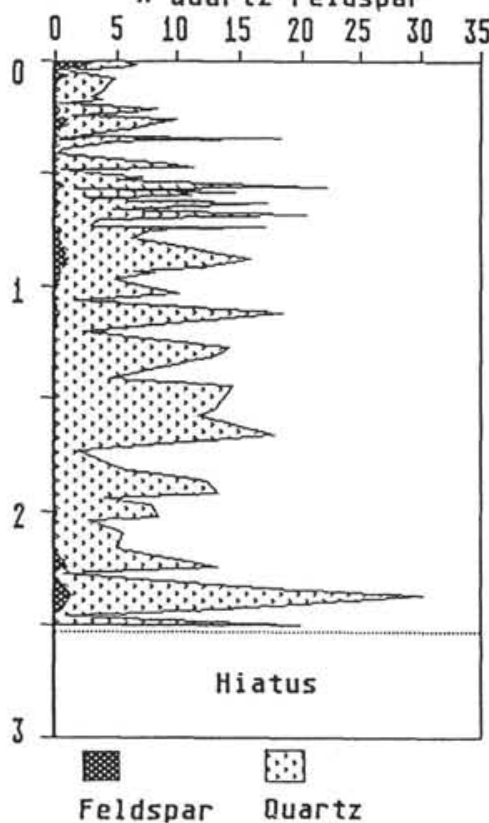

Leg 184, Hole 6428

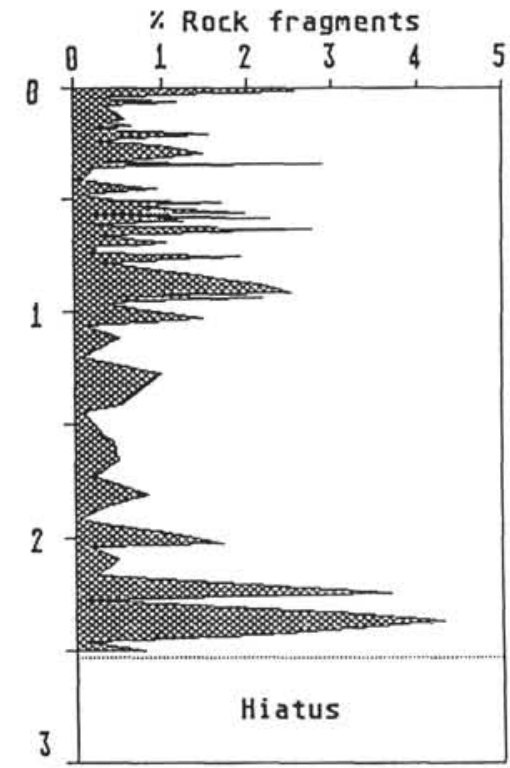

3

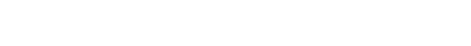

Figure 13. Cyclicity in inputs of ice-rafted debris and carbonate productivity since 2.6 Ma in Hole $642 \mathrm{~B}$. Note that considerable amounts of planktonic and benthic foraminifers have been found only in sediments younger than $0.9 \mathrm{Ma}$. All values are expressed as weight percentages on bulk sediment. 

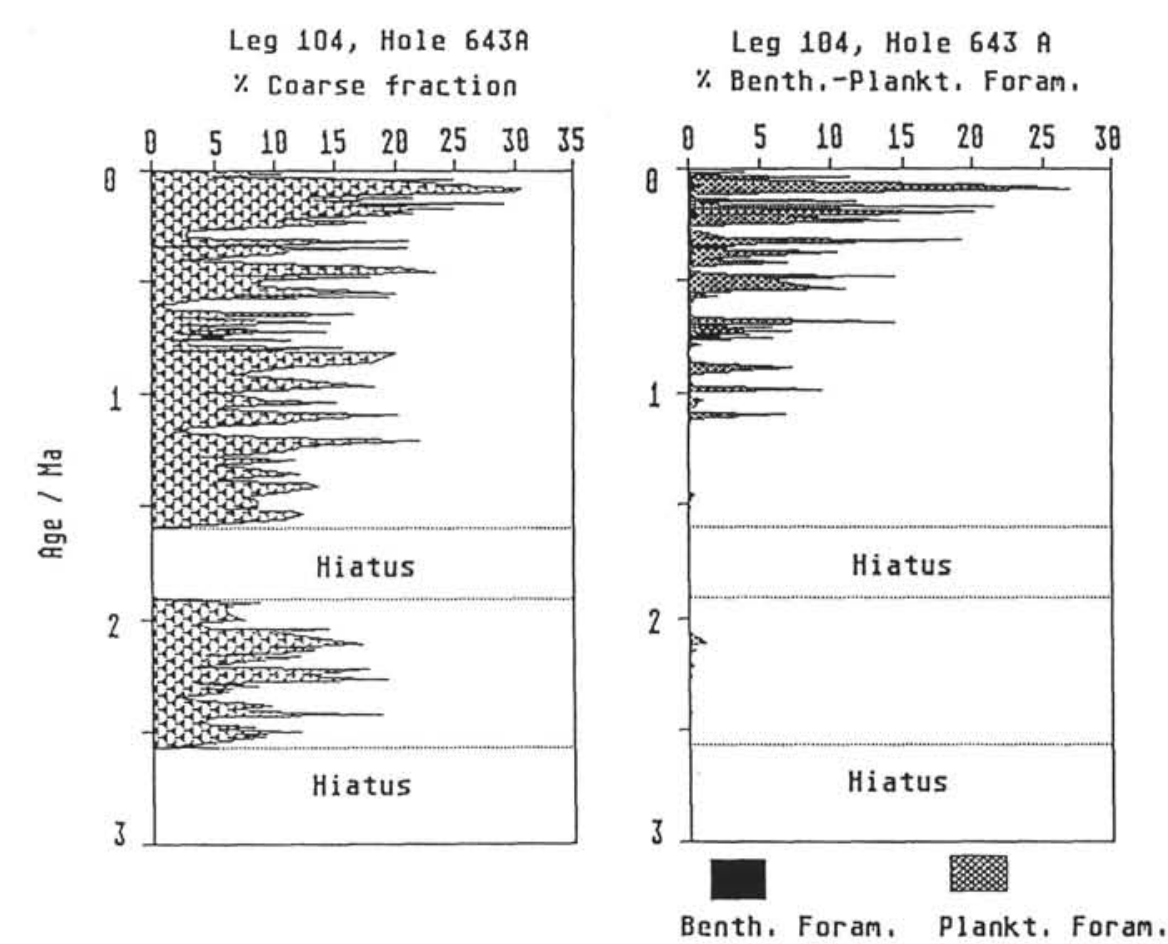
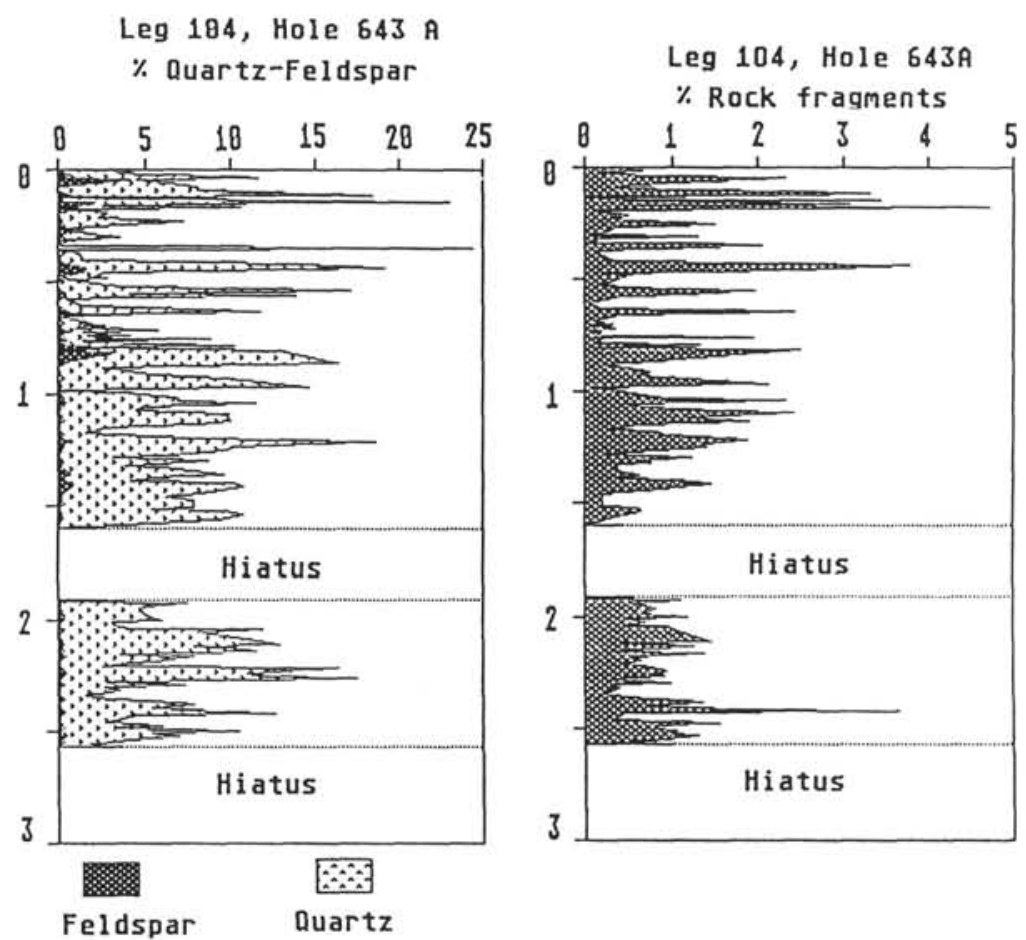

Figure 14. Cyclicity in inputs of ice-rafted debris and carbonate productivity since 2.6 Ma in Hole 643A. Note that considerable amounts of planktonic and benthic foraminifers have been found only in sediments younger than 1.2 Ma. All values are expressed as weight percentages on bulk sediment. 

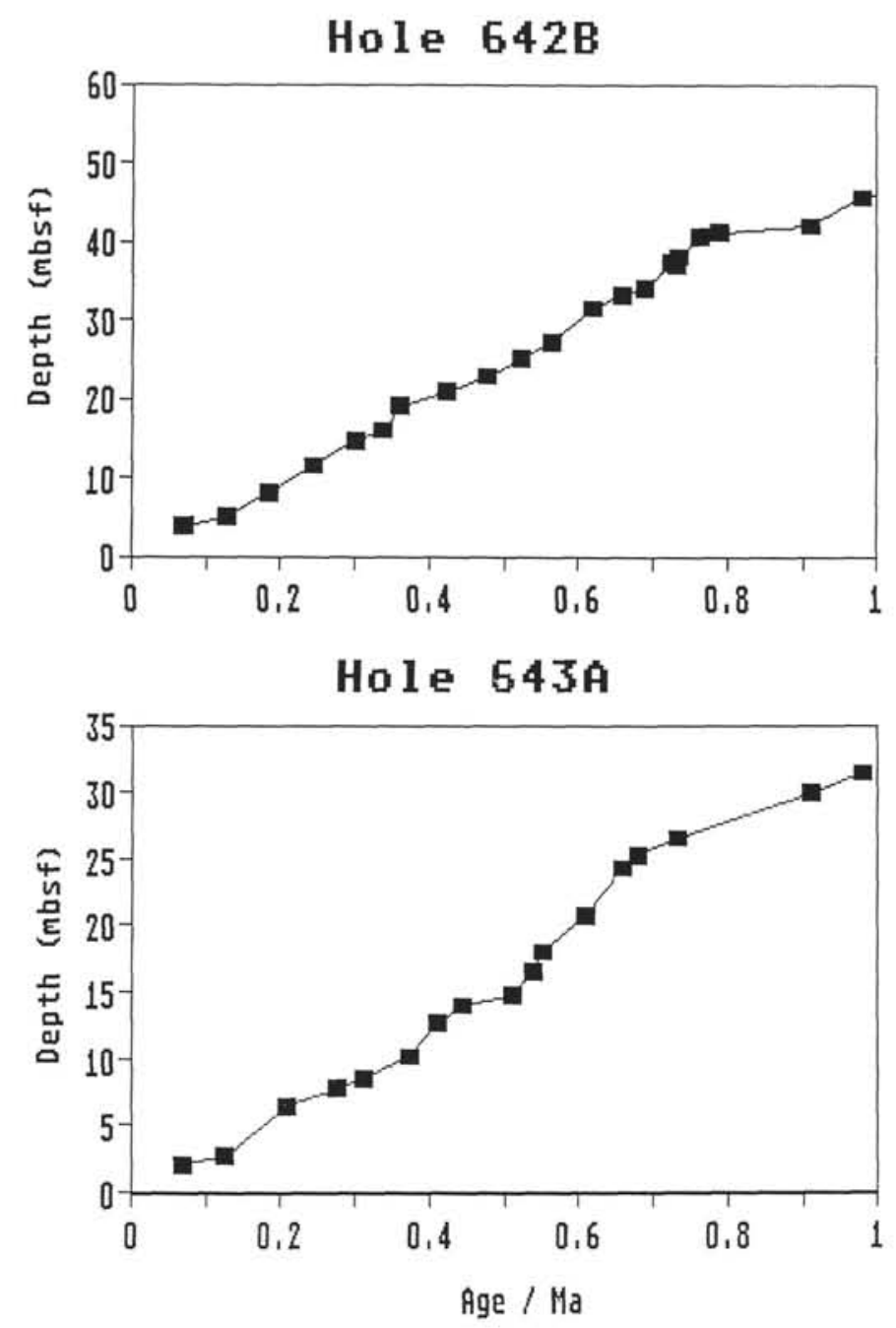

Figure 15. Age/depth diagram, Holes 642B and 643A.

23B). Strong iceberg drift in the southern sector of the Norwegian Sea might have partially blocked off surface-water connections with the North Atlantic by piling up large ice barriers along the Iceland-Faeroe-Shetland Ridge (Wohlfeil, 1982, 1983). Surface-water environments were than be affected by rapid icerafting and strongly reduced surface-water salinities such as in the modern Arctic (Swift, 1986). Deep-water renewal and circulation in the eastern Norwegian-Greenland Sea was strongly depressed resulting in more oxygen-depleted conditions (altogether reflecting the principle circulation outlined in the "humid adjacent sea model"; Seibold and Berger, 1970). Calved icebergs distributed sediments incorporated into continental ice, including frozen mud dropstones. Rapid accumulation of ice-rafted debris was accompanied by resuspension of organic matter possibly derived from reworked, diagenetically altered, organic carbon-rich Cretaceous to Tertiary sediments. Decreased renewal of deep waters and partial oxidation of the resuspended organic matter at the sea floor caused increased dissolution of the already reduced pelagic rain of carbonate tests from the surface waters.

When deglaciation started, sea level rose, and a progressive northward intrusion of the Norwegian Current occurred with warm Atlantic water along the Norwegian Continental Margin dominating the oceanography (Fig. $23 \mathrm{~b}, \mathrm{c}$ ). Rapid rise of sea level most probably caused sudden disintegration of the marinebased parts of the continental ice shield. Glacier surging, with large-scale calving of icebergs into the sea, is the scenario envisaged, affecting the Norwegian Shelf. Surface waters would be affected by sediment-laden meltwater suspensions introduced from the base of large tidewater glacier fronts on the shelf (Molnia, 1983; Powell, 1983; Pfirman and Solheim, unpublished data). Meltwater from the combined effects of melting icebergs and glacial meltwater discharge would form a surface low-density layer, reducing surface productivity and inhibiting vertical mixing (compare Hald and Vorren, 1987). This scenario is substantiated by the regional contours of late glacial/early deglacial sediment supply in the Norwegian Sea (Henrich et al., in press); the diamictons forming offshore lobes, which portray the contours of the continental margin, and grade into oxic sediments far offshore reflecting a westward decrease in concentrations of dropstones.

The upper glacial/lower deglacial lithofacies (D, E, F) do not occur exactly at the transitions in the oxygen isotope records but end 8 to $19 \mathrm{~cm}$ below (Henrich et al., in press). Hence, there is a clear time lag of 3 to $5 \mathrm{k}$.y. between upper glacial/lower deglacial sedimentological record seen in Norwegian Sea deep-sea sediments and the major warming documented in the oxygen isotope records. This lag indicates that these large inputs of icerafted debris document late glacial to very early deglacial periods when marine-based parts of the continental ice on the shelf surged, causing rapid ice rafting in surface waters. Once this was completed, meltwater discharge and iceberg drift from melting of the large remaining ice cap over the Scandinavian continent was drained along areas progressively closer to the coast, while further offshore, carbonate production in surface waters increased.

In lithofacies types B and A an increase in carbonate productivity in the Norwegian Current concomitant with a decrease in ice rafting is observed (Fig. 23c). Vertical mixing is reactivated and bottom waters return to less oxygen-depleted conditions in the entire basin. Rapid exchange of bottom-water and increased production of Norwegian Sea deep water (NSDW) in the western and northern sectors of the Norwegian-Greenland Sea resulted in good carbonate preservation at the sea floor.

Less complete upper glacial/lower deglaciation sequences were most commonly established during glacial stages or within weak interglacial stages, i.e., stages 13, and 15 (Figs. 11, 12). During these periods large-scale surges occurred at the front of the continental ice sheet on the shelf but intrusion of Atlantic water was not sufficient to develop a normal interglacial Norwegian Current with its typically high carbonate productivity (Fig.23b). Additionally, vertical mixing and therefore oxygenation of bottom waters during these minor deglaciations of the marinebased part of the continental ice was less efficient, resulting in a reduced oxygen level.

Depositional and early diagenetic features detected in the upper glacial/lower deglaciation sediments are summarized in Fig. 24. A reduced exchange of bottom water and high inputs of predominantly mature organic matter to the deep-sea floor by ice rafting and resuspension of Cretaceous to Tertiary shelf sediments resulted in high carbonate corrosivity of bottom waters. Because of the predominant nature of organic carbon contained in facies D, E, and F during deposition, considerable amounts were not oxidized but were buried with the sediment. Anoxic conditions were already achieved during incipient burial and caused precipitation of monosulfides. During later stages of early diagenesis, e.g., during the deposition of oxic sediments of facies B and A on top of the anoxic sediments of facies D, E, and $F$, a secondary oxidation by downward diffusion of oxic pore waters and upward diffusion of reduced iron and manganese occured which affected the topmost layers of facies D, E, and F. Iron-hydroxide or iron oxide crusts were precipitated, causing incipient lithification of this layer. Mn precipitated higher within the oxic brownish layers as dark Mn oxide bands (Henrich 
Table 2. Age determinations and LSR, Holes 642B, 643A.

\begin{tabular}{|c|c|c|c|c|c|c|c|}
\hline $\begin{array}{l}\text { Age } \\
\text { (k.y.) }\end{array}$ & Data char. $^{a}$ & Data name & $\begin{array}{l}\text { Depth } \\
\text { (mbsf) }\end{array}$ & $\begin{array}{l}\text { Diff. } \\
(\mathrm{m})\end{array}$ & Diff. age & $\begin{array}{c}\text { LSR } \\
(\mathrm{cm} / \mathrm{k} . \mathrm{y} .)\end{array}$ & Stage \\
\hline Hole $642 B$ & & & & & & & \\
\hline 71 & I & Stage $4 / 5$ & 3.85 & & & & \\
\hline 128 & I & Stage $5 / 6$ & 5.00 & 1.15 & 57 & 2.02 & 5 \\
\hline 186 & I & Stage $6 / 7$ & 8.20 & 3.20 & 58 & 5.52 & 6 \\
\hline 245 & I & Stage $7 / 8$ & 11.50 & 3.30 & 59 & 5.59 & 7 \\
\hline 303 & I & Stage $8 / 9$ & 13.00 & 1.50 & 58 & 2.59 & 8 \\
\hline 339 & I & Stage $9 / 10$ & 15.20 & 2.20 & 36 & 6.11 & 9 \\
\hline 362 & I & Stage $10 / 11$ & 18.40 & 3.20 & 23 & 13.91 & 10 \\
\hline 423 & I & Stage $11 / 12$ & 20.10 & 1.70 & 61 & 2.79 & 11 \\
\hline 478 & I & Stage $12 / 13$ & 22.80 & 2.70 & 55 & 4.91 & 12 \\
\hline 524 & I & Stage $13 / 14$ & 25.00 & 2.20 & 46 & 4.78 & 13 \\
\hline 565 & I & Stage $14 / 15$ & 27.20 & 2.20 & 41 & 5.37 & 14 \\
\hline 620 & I & Stage $15 / 16$ & 31.50 & 4.30 & 55 & 7.82 & 15 \\
\hline 659 & I & Stage $16 / 17$ & 33.20 & 1.70 & 39 & 4.36 & 16 \\
\hline 689 & I & Stage $17 / 18$ & 34.00 & 0.80 & 30 & 2.67 & 17 \\
\hline 726 & I & Stage $18 / 19$ & 37.30 & 3.30 & 37 & 8.92 & 18 \\
\hline 733 & M & Brunhes/Matuyama & 37.11 & & & & \\
\hline 736 & I & Stage $19 / 20$ & 38.10 & 0.80 & 10 & 8.00 & 19 \\
\hline 763 & I & Stage $20 / 21$ & 40.50 & 2.40 & 27 & 8.89 & 20 \\
\hline 790 & I & Stage $21 / 22$ & 41.20 & 0.70 & 27 & 2.59 & 21 \\
\hline 910 & M & Top Jaramillo & 41.96 & 0.76 & 120 & 0.63 & \\
\hline 980 & M & Base Jaramillo & 45.56 & 3.60 & 70 & 5.14 & \\
\hline 1660 & M & Top Olduvai & 52.75 & 7.19 & 680 & 1.06 & \\
\hline 1880 & M & Base Olduvai & 55.15 & 2.40 & 220 & 1.09 & \\
\hline 2470 & M & Matuyama/Gauss & 64.65 & 9.50 & 590 & 1.61 & \\
\hline 2560 & $\mathrm{~S}$ & end gl./Igl.cycles & 66.70 & 2.05 & 90 & 2.28 & \\
\hline \multicolumn{8}{|l|}{ Hole $643 \mathrm{~A}$} \\
\hline 27 & I & Stage $2 / 3$ & 0.70 & & & & \\
\hline 59 & I & Stage $3 / 4$ & 1.95 & 1.25 & 32 & 3.91 & 3 \\
\hline 71 & I & Stage $4 / 5$ & 2.10 & 0.15 & 12 & 1.25 & 4 \\
\hline 128 & 1 & Stage $5 / 6$ & 3.50 & 1.40 & 57 & 2.46 & 5 \\
\hline 186 & I & Stage $6 / 7$ & 6.50 & 3.00 & 58 & 5.17 & 6 \\
\hline 245 & I & Stage $7 / 8$ & 7.80 & 1.30 & 59 & 2.20 & 7 \\
\hline 303 & I & Stage $8 / 9$ & 8.60 & 0.80 & 58 & 1.38 & 8 \\
\hline 339 & I & Stage $9 / 10$ & 10.20 & 1.60 & 36 & 4.44 & 9 \\
\hline 362 & 1 & Stage $10 / 11$ & 12.70 & 2.50 & 23 & 10.87 & 10 \\
\hline 423 & I & Stage $11 / 12$ & 14.00 & 1.30 & 61 & 2.13 & 11 \\
\hline 478 & I & Stage $12 / 13$ & 14.80 & 0.80 & 55 & 1.45 & 12 \\
\hline 524 & 1 & Stage $13 / 14$ & 16.60 & 1.80 & 46 & 3.91 & 13 \\
\hline 565 & I & Stage $14 / 15$ & 18.05 & 1.45 & 41 & 3.54 & 14 \\
\hline 620 & I & Stage $15 / 16$ & 18.80 & 0.75 & 55 & 1.36 & 15 \\
\hline 659 & I & Stage $16 / 17$ & 19.80 & 1.00 & 39 & 2.56 & 16 \\
\hline 689 & I & Stage $17 / 18$ & 20.80 & 1.00 & 30 & 3.33 & 17 \\
\hline 726 & 1 & Stage $18 / 19$ & 24.30 & 3.50 & 37 & 9.46 & 18 \\
\hline 736 & I & Stage $19 / 20$ & 25.20 & 0.90 & 10 & 9.00 & 19 \\
\hline 733 & M & Brunhes/Matuyama & 26.56 & & & & \\
\hline 763 & I & Stage $20 / 21$ & 27.50 & 2.30 & 27 & 8.52 & 20 \\
\hline 790 & I & Stage $21 / 22$ & 27.90 & 0.40 & 27 & 1.48 & 21 \\
\hline 910 & $\mathrm{M}$ & Top Jaramillo & 29.94 & 2.04 & 120 & 1.70 & \\
\hline 980 & M & Base Jaramillo & 31.46 & 1.52 & 70 & 2.17 & \\
\hline 1600 & \multicolumn{2}{|c|}{ Hiatus 1.6 to $1.9 \mathrm{Ma}$} & 40.01 & 8.55 & 620 & 1.38 & \\
\hline 2470 & $\mathrm{M}$ & Matuyama/Gauss & 49.42 & 9.41 & 870 & 1.08 & \\
\hline 2560 & $\mathrm{~S}$ & End Gl,/Igl.cycles & 51.26 & 1.84 & 90 & 2.04 & \\
\hline
\end{tabular}

${ }^{\mathrm{a}} \mathrm{I}$ : isotope, M: magnetic, S: sedimentologic.

et al., in press). The very early nature of these processes is confirmed by burrows truncating the iron bands and filled with oxic sediments (Fig. 5). Assuming an analoguous vertical penetration of the Planolites-type burrows as in the modern Arctic environment (i.e. $10-20 \mathrm{~cm}$ ), one may calculate the maximum time span between formation of the diagenetic iron lamination and the onset of the burrowing activity to within the order of 1 to 5 k.y. using linear sedimentation rates.

\section{MAJOR CHANGES IN SURFACE- AND BOTTOM-WATER CIRCULATION IN THE NORWEGIAN SEA DURING THE LATE PLIOCENE TO QUATERNARY}

The long interval from $2.56 \mathrm{Ma}$ to $1.2 \mathrm{Ma}$ displays a completely different surface and deep-water circulation pattern from that during the past 800 k.y. Vertical mixing and surface-water productivity were considerably reduced throughout most of this interval and strong dissolution occurred at the sea floor. Climatic cyclicity is only indicated in the persistent fluctuations of ice-rafted debris and weak intrusions of warm Atlantic water over Site 644. The Brunhes circulation system with its strong east-west gradients reflecting the contrast of inflowing cold Arctic and warm Atlantic water in the Norwegian-Greenland Sea was not yet completely established. Occasional weak intrusions of warm Atlantic currents might have accelerated deglaciation of marine-based parts of the Scandinavian ice shield, but were much less effective with respect to their capacity for decreasing the total ice volume over Scandinavia and Greenland. As a consequence, seasonal extremes and the import of highly saline warm waters within this overall glacial setting must have been less severe, resulting in a much smaller increase in volume of the ice cap over Scandinavia. As a result, an almost persistent 


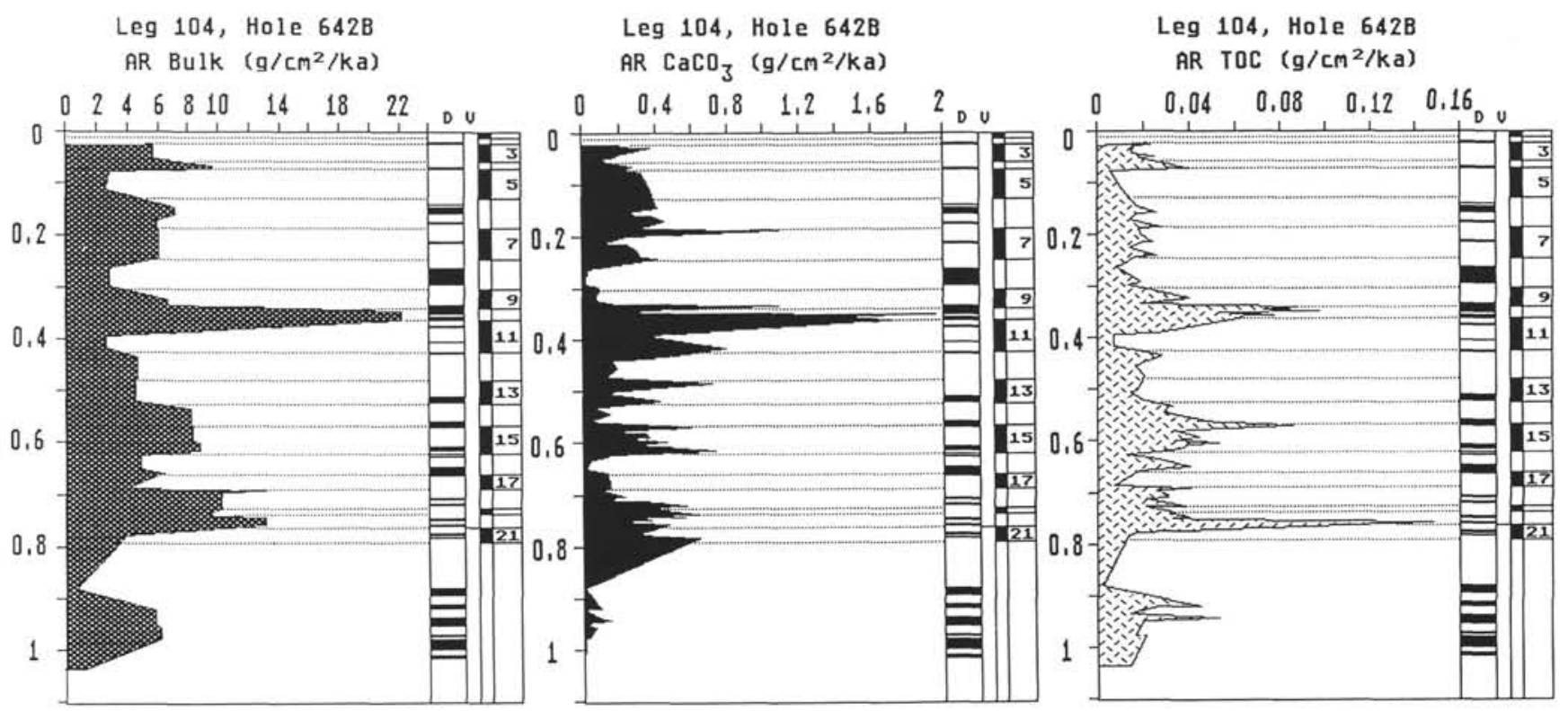

Figure 16. Bulk-, carbonate-, and organic carbon accumulation rates in Hole 642B during the last $1 \mathrm{~m} . \mathrm{y}$. (D $=$ dark lithofacies, $\mathrm{V}=$ volcanic ash beds). Bulk sediment and organic carbon fluxes roughly show a repetition of two $400-k . y$. trends during the past 800 k.y. Extraordinary high bulk sediment and organic carbon fluxes are observed during stages 20 to 18,15 to $14,10,7$ to 6,4 to 3 . The maximum carbonate flux occurred during stage 11. Additional high carbonate fluxes are observed during stages $21,19,15,13,9$, and 7.

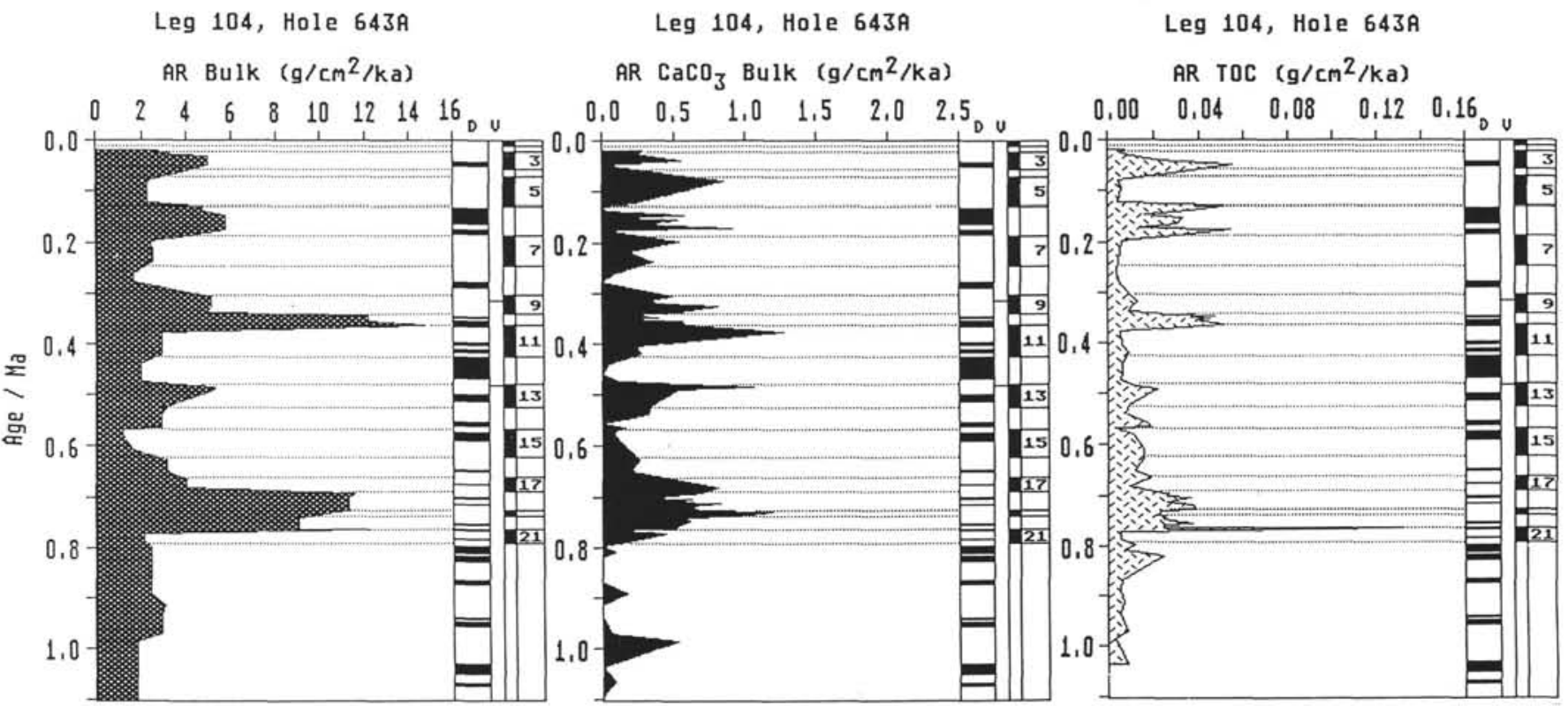

Figure 17. Bulk-, carbonate-, and organic carbon accumulation rates in Hole 643A during the last 1 m.y. (D = dark lithofacies, $\mathrm{V}=$ volcanic ash beds). Bulk sediment and organic carbon fluxes show a repetition of two roughly $400-\mathrm{k}$.y. trends during the past $800 \mathrm{k}$.y. Extraordinary high bulk sediment and organic carbon fluxes are observed during stages 20 to $18,10,6$, and 3 . Maximum carbonate fluxes were attained during stages 11,13 , and 19. Additional high carbonate fluxes occurred during stages 17,9 , and 5 .

but smaller ice cap might have existed over Scandinavia and Greenland resulting in a predominantly zonal atmospheric circulation that might have been driven by katabatic winds. A winter sea-ice coverage and a summer pack-ice and iceberg drift situation might be envisaged. Lowered surface salinities (compare planktonic foraminifer isotope records, Jansen et al., in press; Jansen et al., this volume) might have covered wide areas of the Norwegian Sea under these conditions. Surface currents generally are assumed to have been rather weak, possibly forming a single gyre within the Norwegian-Greenland Sea. Surface-water exchange with the North Atlantic was minimized, and vertical mixing in the Norwegian Sea was strongly reduced. Deep-water formation in northern and western regions of the NorwegianGreenland Sea must have been less intensive and should have formed by processes other than those found today.

During the last 800 k.y. the climatic oscillations of glacials and interglacials follow roughly a 100-k.y. cycle in the Norwegian Sea. A 400-k.y. trend is superimposed on this pattern, reflecting a prominent mid-Brunhes change that might record long-term shifts in the build-up and disintegration of the conti- 

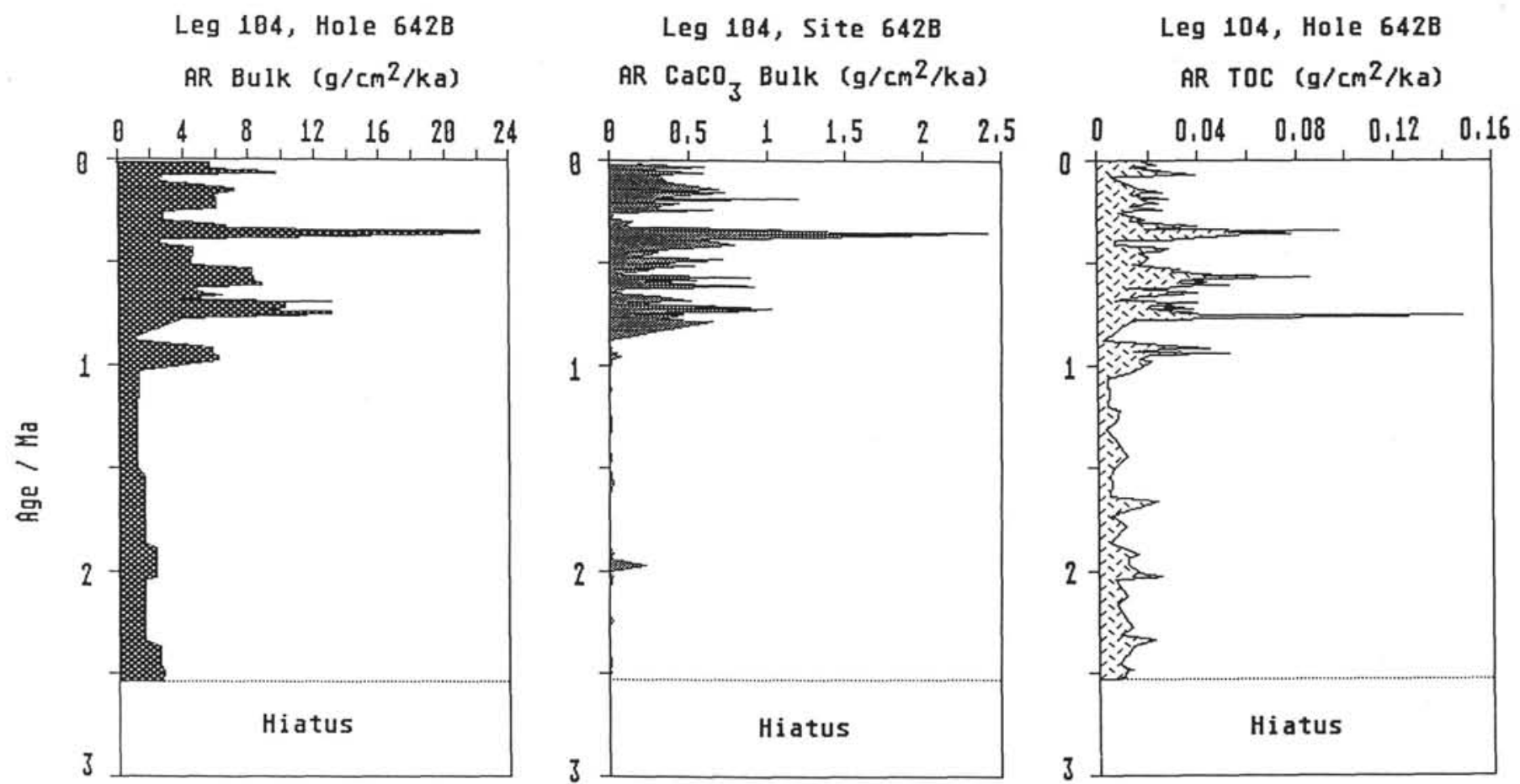

Figure 18. Bulk-, carbonate-, and organic carbon accumulation rates in Hole 642B during the last 2.6 m.y. Note drastic decrease in bulk-sediment fluxes and almost complete loss of carbonate prior to $1 \mathrm{Ma}$.
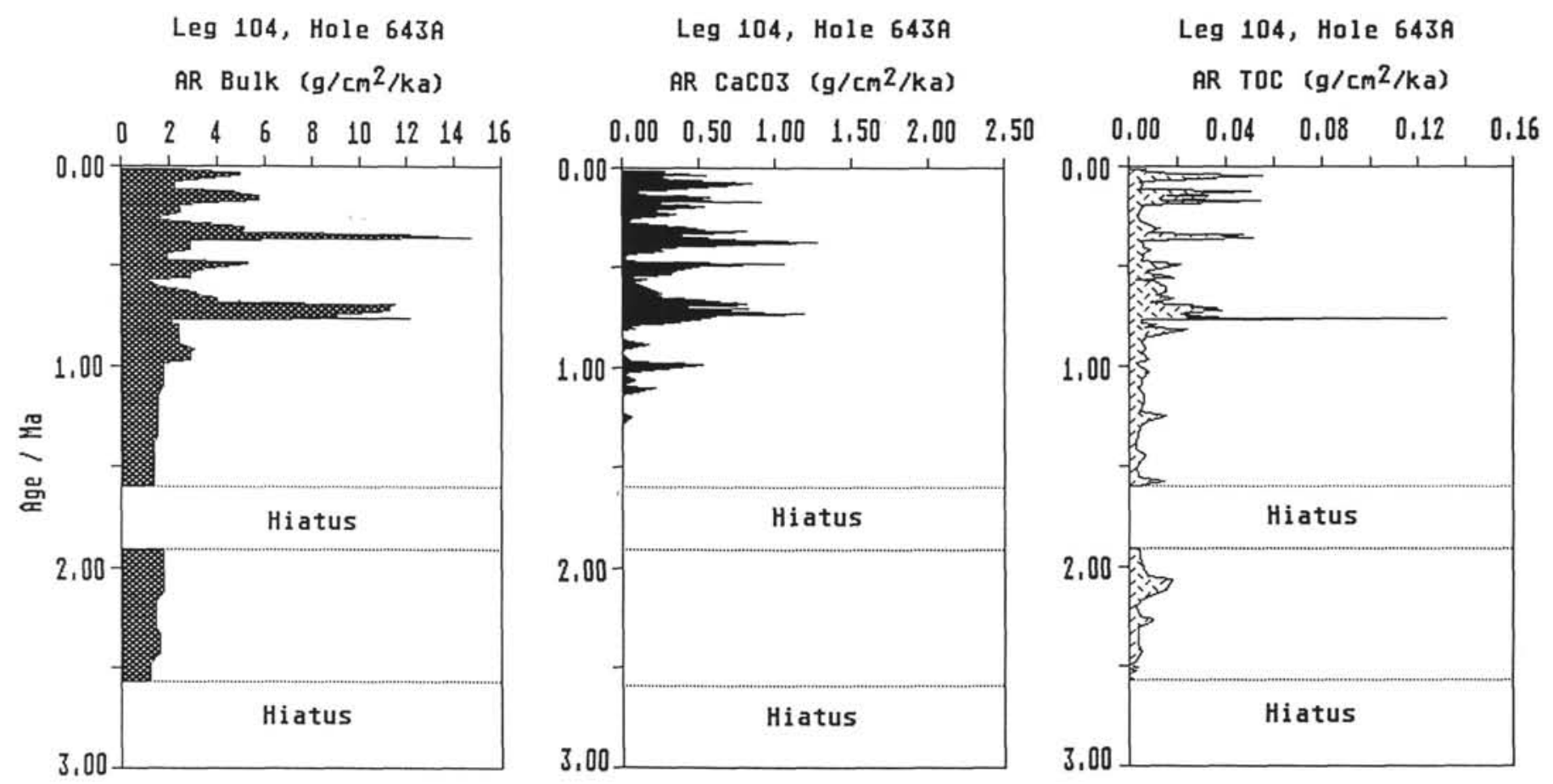

Figure 19. Bulk-, carbonate-, and organic carbon accumulation rates in Hole 643A during the last 2.6 m.y. Note drastic decrease in bulk sediment fluxes and almost complete loss of carbonate prior to $1.2 \mathrm{Ma}$.

nental ice shield over Scandinavia and in the Laurentide ice shield. Cyclic fluctuations in carbonate productivity reflect variations in the intensity and extension of the warm Norwegian Current system, with strongest influence during stages 5,11 , and 13. During the most severe glacial periods, wide areas of the Norwegian Shelf have been covered with continental ice (King et al., 1987). Subsequently there occurred rapid deglaciation with attendant surging and collapse of the continental shelf ice shield and a widespread low-salinity and sediment-laden surface layer along the continental margin. Increased resuspension of terrigenous organic matter resulted in pulses of strong carbonate dissolution at the sea floor and temporal, stable, water-mass strati- 

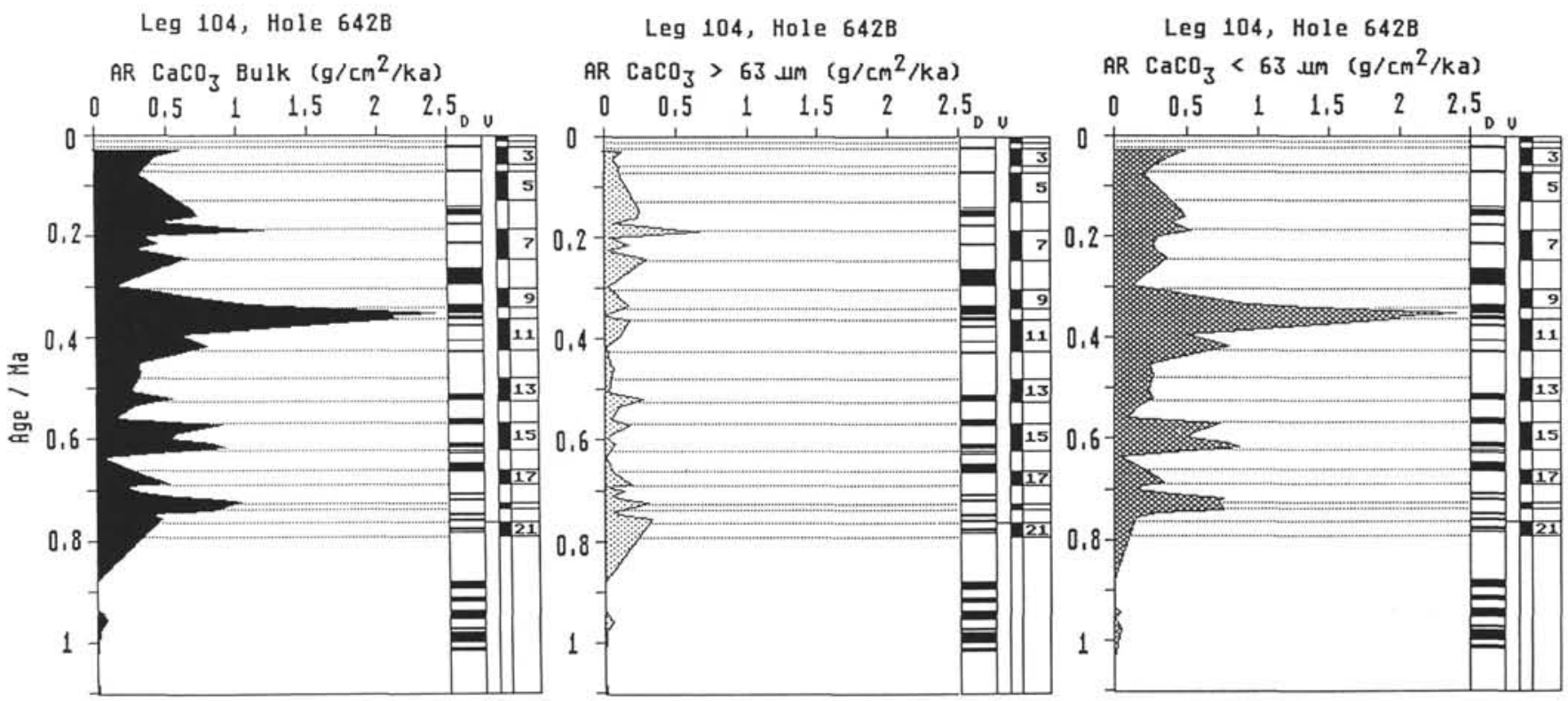

Figure 20. Bulk-, coarse-, and fine-fraction carbonate accumulation rates in Hole 642B during the last 1 m.y. (D $=$ dark lithofacies, $\mathrm{V}=$ volcanic ash beds). Note predominance of fine-fraction carbonate in total carbonate fluxes.

Leg 104, Hole 643A

AR $\mathrm{CaCO}_{3}$ Bulk $\left(\mathrm{g} / \mathrm{cm}^{2} / \mathrm{ka}\right)$

$\begin{array}{llllllll}0,0 & 0,2 & 0,4 & 0,6 & 0,8 & 1,0 & 1,2\end{array}$

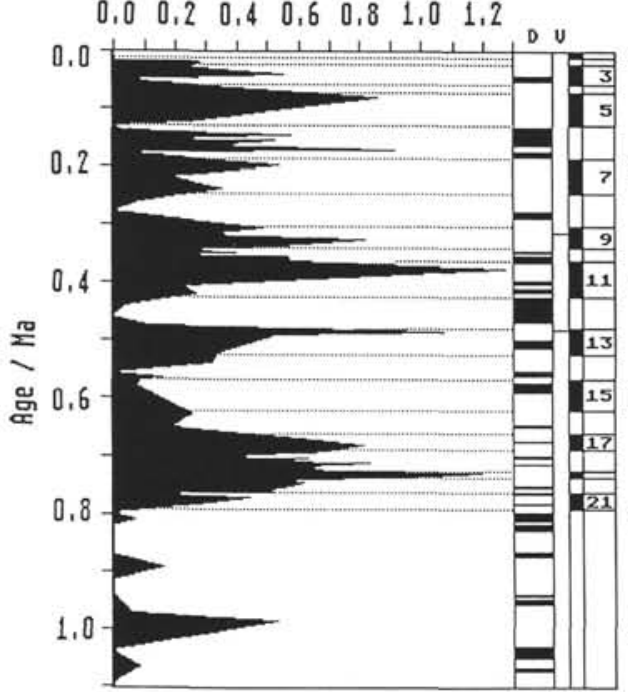

Leg 104, Hole 643A AR $\mathrm{CaCO}_{3}>63 . \mu \mathrm{m}\left(\mathrm{g} / \mathrm{cm}^{2} / \mathrm{ka}\right)$

$\begin{array}{lllllll}0,0 & 0,2 & 0,4 & 0,6 & 0,8 & 1,0 & 1,2\end{array}$

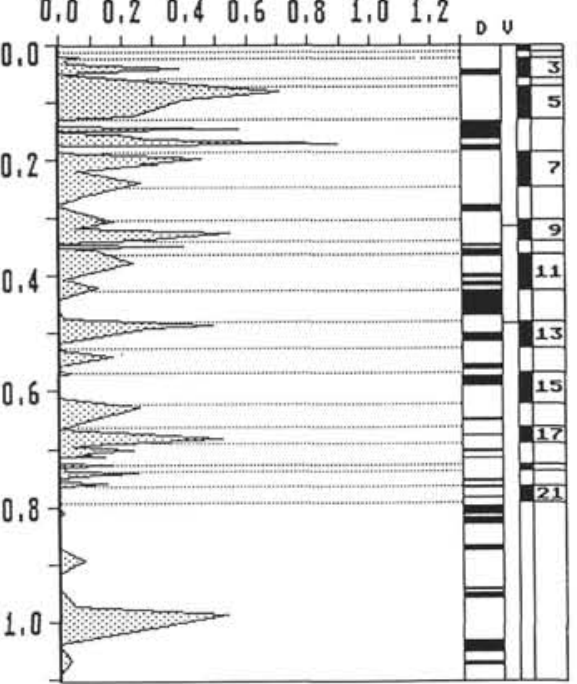

Leg 104, Hole 643A AR $\mathrm{CaCO}_{3}<63 \mathrm{um}\left(\mathrm{g} / \mathrm{cm}^{2} / \mathrm{ka}\right)$

$\begin{array}{lllllll}0.0 & 0.2 & 0.4 & 0.6 & 0.8 & 1.0 & 1.2\end{array}$

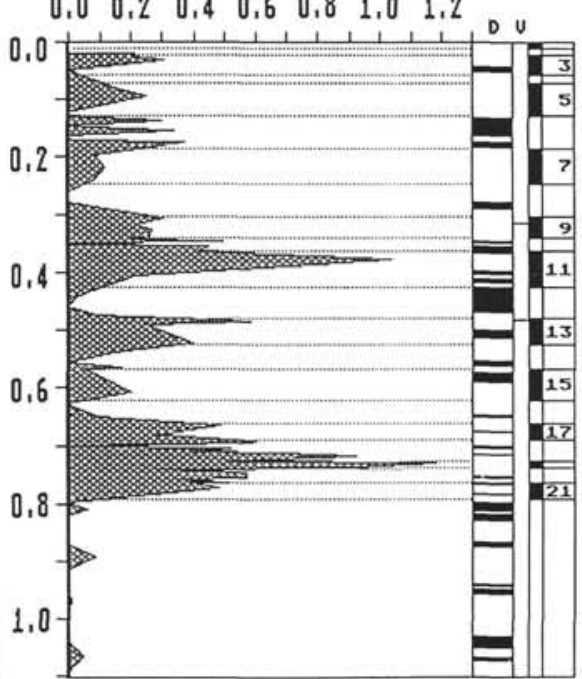

Figure 21. Bulk-, coarse-, and fine-fraction carbonate accumulation rates in Hole 643A during the last $1 \mathrm{~m} . \mathrm{y}$. (D $=$ dark lithofacies, $\mathrm{V}=$ volcanic ash beds). Coarse-fraction-dominated carbonate fluxes are evident during stages 7, 6, and 5 . Equivalent amounts of coarse- and fine-fraction carbonate were deposited during stages 13 and 9 . Stages 21 to $14,11,10$, and 8 reflect fine-fraction-dominated carbonate fluxes.

fication might have strongly reduced vertical mixing and deepwater circulation.

\section{EVOLUTION OF LATE PLIOCENE TO QUATERNARY NORTHERN HEMISPHERE CLIMATE}

The sedimentological records of the Leg 104 drill sites clearly show that the first major consistent expansion of the Scandinavian ice sheet occured at about $2.56 \mathrm{Ma}$. This is somewhat older than the $2.36 \mathrm{Ma}$ reported for the first major ice-rafted debris from Site 552 (Shackleton et al., 1984), 2.45 Ma from Site 609 (Raymo et al., 1987) and 2.5 Ma from Sites 646 and 647 (Srivastava, Arthur, et al., 1987). The Leg 104 cores do not document any older major glaciation over Scandinavia before $2.56 \mathrm{Ma}$, although earlier glacial phases are described at about $3 \mathrm{Ma}$ for Iceland (Einarsson et al., 1967) and repeated input of ice-rafted debris occurred during the late Miocene in the Arctic Ocean (Clark et al., 1983). Recent quantitative biostratigraphic and paleomagnetic reevaluation of Arctic Ocean chronology has confirmed a minimum age of $4 \mathrm{Ma}$ for the deepest ice-rafted debris 
A Lithofacies-
type

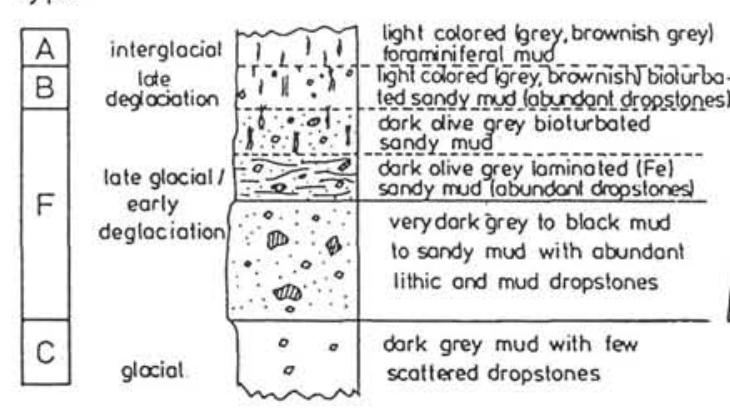

Mud - dropstone rich diamictons, dark grey. transitional to dark olive grey.

B

Dark olive grey mud - dropstone rich diamictons

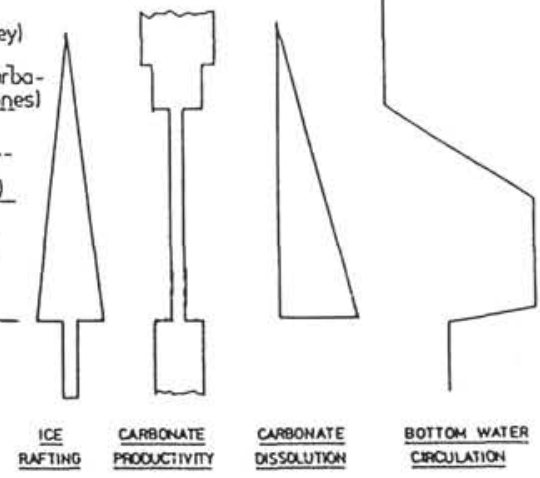

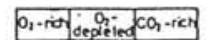

CRBONATE BOTTOM WATER

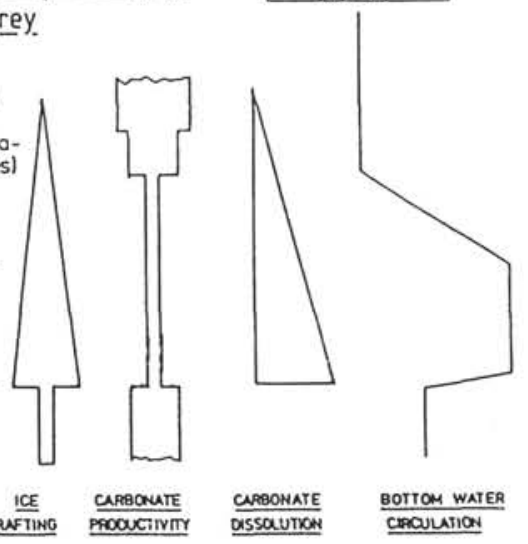

KCE.
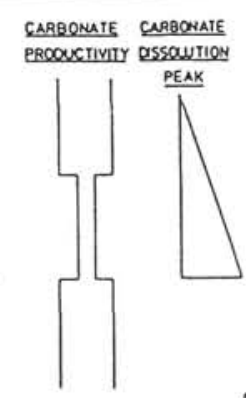

BOTOM WATER

\begin{tabular}{|l|}
\hline$C$ \\
\hline$D$ \\
\hline$C$ \\
\hline
\end{tabular}
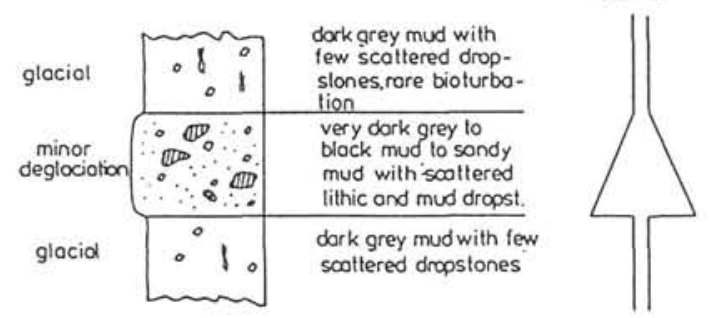

arcuatio

Dark olive grey mud - dropstone rich diamictons

ICE - CABBONATE CARBONATE RAFTONO PROQUCTIVITY QSSSQUVTiON

BOHOM WATER Cressution
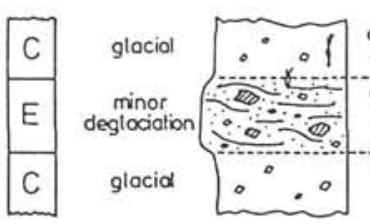

dork grey mud with few scottered dropstones
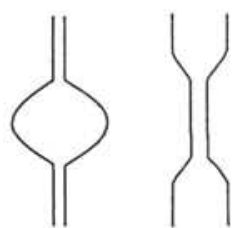

PEAK

Mud-dropstone rich diamictons, dark grey transitional to dark olive grey

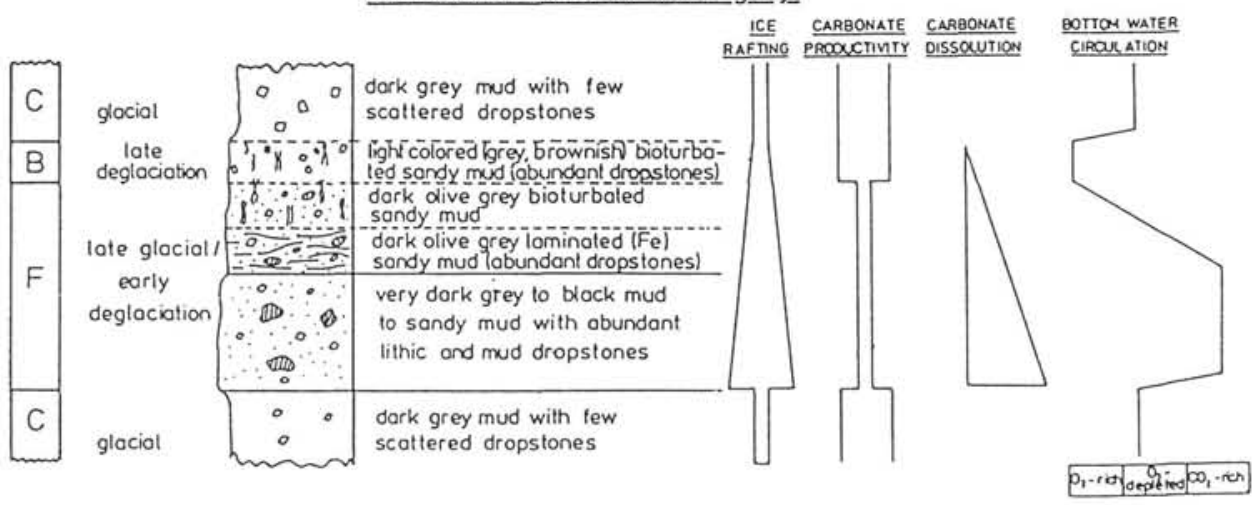

Figure 22. Compilation of basic lithofacies successions deposited during late glacial to interglacial periods (A) and during periods of maximum glacial advance and subsequent disintegration of the marine-based parts of the continental ice shields (B). Environmental changes in surface and bottom-water properties are indicated on a semiquantitative scale. 

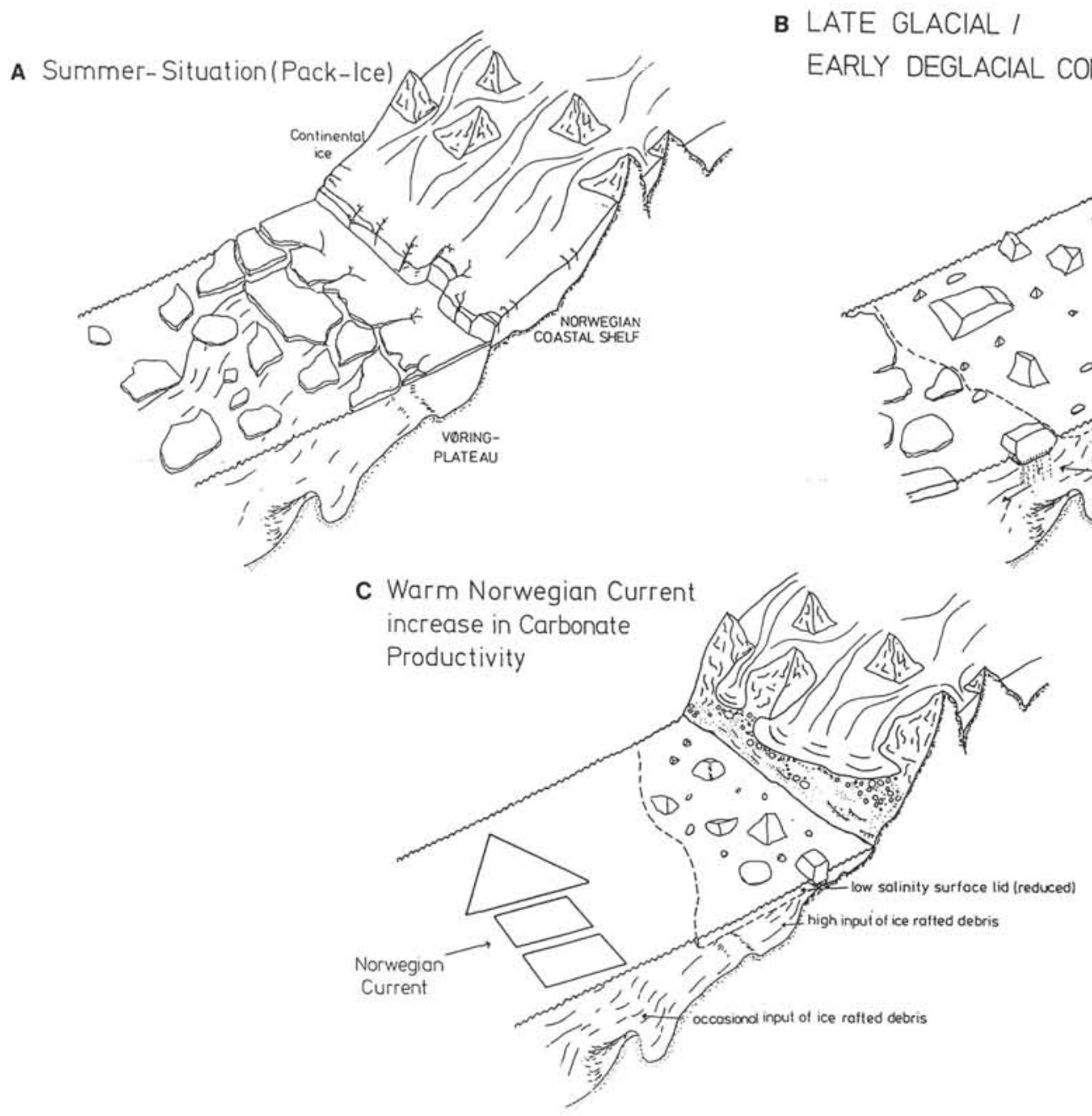

Figure 23. Conceptual paleoenvironmental model, A. strong glaciation reflecting advance of continental ice sheets on the Norwegian coastal shelf associated with offshore pack-ice drift; B. late glacial/early deglacial strong iceberg drift induced by surges of the marine-based parts of continental ice; surface-water connection with the North Atlantic may be partially blocked off by high iceberg barriers; C. Early interglacial progressive intrusion of the Norwegian Current with iceberg drift close to the coastal areas and offshore increase in carbonate productivity.

in the central and western Arctic (Aksu and Mudie, 1985; Aksu, 1985; Clark et al., 1986). Marquard and Clark (1987) propose a correlation of northern Greenland Sea and central Arctic Ocean cores based on combined isotopic and micropaleontological evidence. Northern Greenland Sea sedimentation rates are supposed to be an order of magnitude greater than those in the central Arctic Ocean. Leg 104 Miocene to Pliocene records indicate various earlier phases of climatic cooling in the Northern Hemisphere that preceeded the onset of major glaciation over Scandinavia at $2.56 \mathrm{Ma}$ (Henrich et al., this volume; Locker, this volume; Spiegler and Jansen, this volume). As a result, strong asymmetric initial growth of the Northern Hemisphere continental ice shields might be envisaged. A considerably earlier growth of ice shields over the Greenland- Arctic archipelago may be contrasted by a much later build up of ice caps over Scandinavia at 2.56 Ma. Evidence from Site 645 suggests a possible ice-rafted debris input into the Baffin Bay dated as early as $8 \mathrm{Ma}$ (Srivastava, Arthur, et al., 1987).

Previous studies have elaborated on details of the orbital forcings recorded in glacial/interglacial cycles (Imbrie et al., 1984; Herterich and Sarnthein, 1984). Feedback mechanisms of various orders and magnitudes may have exerted modifications on orbital forcings as discussed especially for deglaciation periods by Ruddiman and McIntyre $(1981,1984)$. Previously pub- lished North Atlantic glacial/interglacial carbonate and isotopic records reveal a number of consistent shifts in dominant frequencies during the last $2.5 \mathrm{Ma}$. The period from $2.6 \mathrm{Ma}$ to 1.2 Ma shows a clear prevalence of the 41-k.y. obliquity cycle with low amplitudes in the carbonate and isotopic records, while the interval younger than 800 k.y. ago shows dominance of the 100k.y. cycle (Shackleton et al., 1984; Ruddiman et al., 1986; Marquard and Clark, 1987). This general pattern is also observed in the Leg 104 sites, but correlative investigation is hampered by strong carbonate dissolution prior to $600 \mathrm{k}$.y. ago. In addition a transition period from 0.6 to $1.2 \mathrm{Ma}$ is detected, reflecting an increase in the amounts of ice-rafted debris in the sediments. The last 800 k.y. show a strong $100-k$.y. cyclicity with large amplitudes in the carbonate records. Two 400-k.y. trends during the last 800 k.y., and a third 400-k.y. trend (only recognized in the inputs of ice-rafted debris) may reflect the 400-k.y. longterm eccentricity cycle (Berger et al., 1984) with strong ice build up and a subsequent extraordinarily warm interglaciation at the begining of each cycle.

Ruddiman et al. (1986 a, b) concluded that the observed mid-Pleistocene shift of the dominant ice-sheet response from 41 to 100 k.y. cannot be explained only by variations in received insolation. Another cause they discuss is abrupt increase in the elevation of large mountain ranges, e.g., the Sierra Nevada 
A. Sedimentary Regime

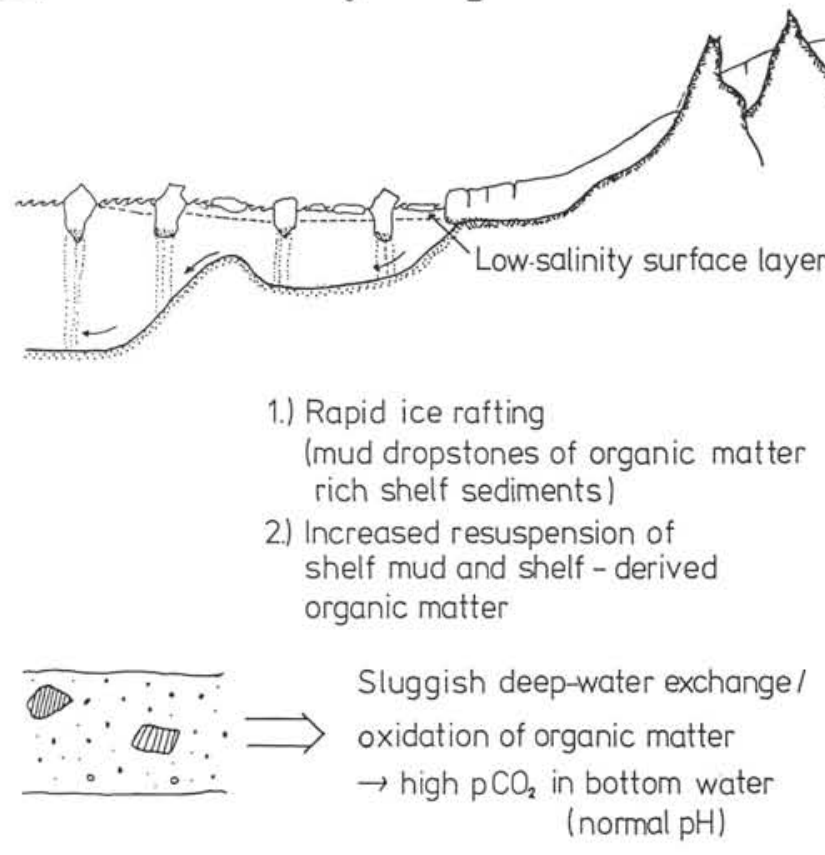

CARBONATE DISSOLUTION
B Early Diagenetic Regime

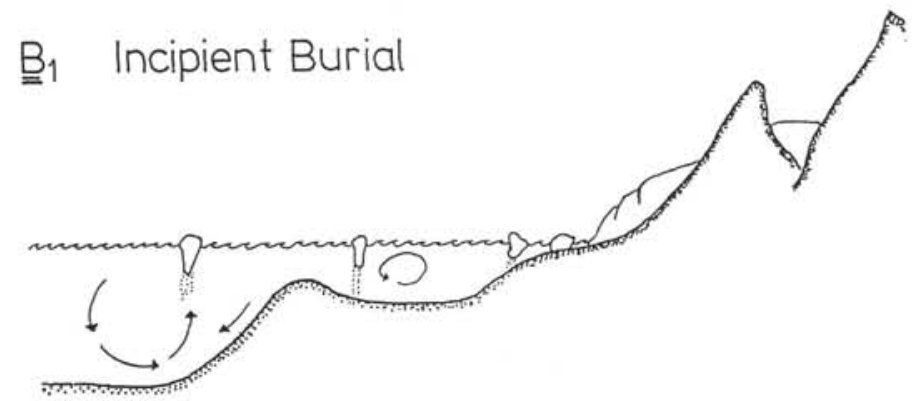

Anoxic conditions within the sulfate reduction zone (high $\mathrm{pH}$, negative Eh) precipitation of monosulfides.

\section{$\underline{\underline{B}}_{2}$ Early Burial}

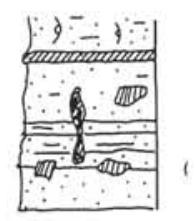

precipitation of $\mathrm{Mn}$-oxides

secondary oxidation of iron (incipient lithification; iron oxides, -hydroxides). dark-brown burrow filling penetrate through the iron lamination.

Figure 24 . Model of early diagenetic processes in late glacial/early deglacial sediments.

Mountains and the Transverse Ranges in the Western United States and the Himalayan Mountains/Tibetian Plateau complex. These rapid uplifts would have strongly influenced the long-wave atmospheric circulation in the Northern Hemisphere. Pleistocene mountain uplift would increase the meridionality in the Northern Hemisphere atmospheric circulation, e.g., increasing storm tracks and inflow of cold polar air masses over North America and Europe, both effects favoring glaciation and reducing ice ablation in summer. Such a tectonic phenomenon could have caused the shift from a 41-k.y. to a 100-k.y. cycle. The resultant huge ice shields, once established, would then exaggerate strong forcings on climate by major changes in the albedo and by rapid iceberg calving and development of a low-salinity layer in surface waters during ice-sheet disintegration. This model can be tested on the paleoclimatic records of the Norwegian-Greenland Sea in the Leg 104 sites. A number of environmental considerations discussed in the previous chapter are in good agreement with the basic assumptions of the model. During the period dominated by the $41-k$.y. cycle a strong zonal gradient must have separated the North Atlantic and the Norwegian-Greenland Sea. A weak intrusion of a warm Atlantic Current temporarily increased the deglaciation of the Scandinavian ice shield, but not to any great extent. As a consequence the import of warm saline water and its evaporation was much lower, resulting in a smaller ice build up during glacial extremes. In conclusion, a smaller but persistent ice cap existed over Scandinavia and Greenland and triggered a more zonal atmospheric circulation driven by katabatic winds, possibly resulting in a weak, single-gyre, surface circulation in the Norwegian-Greenland Sea. Winter sea ice, summer pack ice, and lowered surface salinities with low carbonate productivity are proposed as the most prominent oceanographic features during the major portion of this interval (compare Jansen et al., in press; Jansen et al., this volume).
With regard to the question of the timing of this tectonic cause, e.g., abrupt vs. gradual, evidence in the Leg 104 sites indicates that the change might have been rather gradual, covering the interval from 1.2 Ma to $0.6 \mathrm{Ma}$ (Jansen et al., in press). In addition, changes may have been accelerated around $0.8 \mathrm{Ma}$, favoring interaction of orbital forcing as the most prominent factors.

The climatic response of the last 800 k.y. in the Norwegian Sea shows that a strong 400-k.y. trend superimposed on the 100k.y. signal is initiated by a strong glaciation, e.g., during stages 12 and 22 , followed by a very rapid deglaciation and a very warm interglaciation, e.g., during stages 11 and 21 . The climatic record of Site 609 in the North Atlantic reflects very low $\mathrm{SST}_{\mathrm{w}}$ during isotope stages $22,18,12$, and 10 (Ruddiman et al., 1986) contrasting with much higher $\mathrm{SST}_{w}$ at Site 552 (Shackleton et al., 1984). This might indicate an even stronger meridionality than today. Sarnthein and Stremme (1984) were able to correlate the warm Holsteinian interglaciation in northern Germany and the Netherlands with isotope stage 11 of the deep-sea record. They stated that the large Holsteinian transgression was not a result of an unusually high eustatic sea level, but was the response to an extensive and long-lasting glacial-isostatic depression of the northern German lowlands resulting from the extreme advance of the Elster glaciation, correlated to stage 12. The best carbonate preservation is observed during stage 11 . Considerable amounts of subpolar planktonic foraminifers in Holes $642 \mathrm{~B}$ and $\mathrm{C}$ and $643 \mathrm{~A}$ only occur in stages 5,11 , and 13 (Spiegler and Jansen, this volume), which is in contrast to the results of Kellogg (1978), who only detected higher contents of subpolar planktonics during stage 5 .

In conclusion, consistent evidence in the North Atlantic and Norwegian-Greenland Sea shows that stage 11 was the warmest stage in the Brunhes and that a $400-\mathrm{k} . \mathrm{y}$. trend is reflected by major changes in the volume of the Northern Hemisphere ice sheets. 


\section{CONCLUSIONS}

Glacial/interglacial sedimentary cycles reveal a number of specific lithofacies in the Norwegian Sea which can be attributed to major paleoceanographic settings. Characteristic dark lithofacies sequences are recorded during late glacial/early deglacial periods and during various minor deglaciations within glacial stages. The most complete transition of lithofacies at the glacial terminations reflects a low-salinity surface layer formed during the rapid collapse of the continental ice sheets on the Norwegian shelf. Extensive ice rafting of organic matter-rich shelf sediments and increased resuspension of terrigenous organic material occurred during the late glacial/early deglacial periods. High organic matter deposition resulted in strong carbonate dissolution at the sea floor and, immediately after incipient burial, in anoxic conditions within the sediments. Early interglacial conditions are indicated by a gradual decrease of ice rafting and a gradual reestablishment of carbonate productivity in surface waters. Well-oxygenated bottom waters caused an early diagenetic oxidation of the upper portion of the buried anoxic deglaciation sediments and improved carbonate preservation. Less-complete transitions without a return to fully oxygenated bottom waters characterize minor deglaciations within glacial periods.

Carbonate records of the last 1.2 Ma in the Leg 104 cores reflect a dominant 100-k.y. cycle, on which a $400-\mathrm{k}$.y. trend is superimposed. A similar pattern is seen in the other sedimentological records, e.g., the bulk sediment and organic carbon fluxes, and in the variability of ice-rafted debris inputs. Each of these 400-k.y. trends started with an extraordinarily strong glacial, followed by a rapid deglaciation and a very warm interglacial. Stage 11 reveals the warmest interglacial conditions throughout the Brunhes.

The Matuyama is dominated by a 41-k.y. cyclicity in the North Atlantic sites. Strong zonal gradients exist between the North Atlantic and the Norwegian-Greenland Sea. An overall temperate glacial climate with smaller but persistent ice caps dominated the Northern Hemisphere climate. Katabatic winds drove a weak single-gyre surface circulation in the NorwegianGreenland Sea. Seasonal variations of winter sea-ice coverage, summer pack ice and weak iceberg drift dominated the surfacewater regimes, resulting in overall lowered salinities and low carbonate productivity. Reduced vertical mixing caused strong carbonate dissolution at the sea floor. The interglaciations were much less developed, showing only a weak intrusion of a warm Atlantic Current which was capable of accelerating ice rafting but never attained its full strength and established carbonate productivity as in the Brunhes. Episodic intrusions of the Norwegian Current are only documented at Site 644 , indicating a much narrower extension and closer proximity of the warm Atlantic water to coastal areas.

A transition period from 0.6 to $1.2 \mathrm{Ma}$, indicated by shifts in the stable isotope composition of planktonic and benthonic foraminifers, gradual development of better carbonate preservation, and increases in ice-rafted debris inputs, suggests gradual evolution of the different Brunhes and Matuyama patterns, possibly induced by a gradual large mountain uplift as proposed by Ruddiman et al. (1986 a, b).

\section{ACKNOWLEDGMENTS}

I thank Captain Oonk and the crew of the JOIDES Resolution for their dedicated services during Leg 104, and the shipboard technical and scientific party for assistance in fulfilling the large sampling demands. G. Bohrmann, E.Jansen, S. Pfirmann, J. Thiede, and T. Wolf read drafts of the manuscript and made numerous valuable suggestions. Critical reviews supplied by D. Clark and D. Piper are gratefully acknowledged. I thank U. Drechsler (carbonate and organic carbon measurements), A. Schröder and M. Ruff (handling of samples in the labo- ratory), A. Dettmer, U. Grützmacher, K. Lackschewitz and C. Wieger (analysis of coarse-fraction components), D. Spiegler and A. Freiwald (preparation of planktonic foraminifers for SEM investigation), W. Reimann (SEM operation), U. Struck (drafting), and U. Schuldt (photographic assistance). This study was supported by grants from the German Research Foundation (DFG-grant Th 200/3-4 and grants for the Joint Research Project SFB 313 at Kiel University). A visit at Bergen University that enabled the author to discuss data with colleagues from Bergen is heartily acknowlegded. This is Publication No. 28 of the Special Research Project (SFB 313) at the University of Kiel.

\section{REFERENCES}

Aksu, A. E., 1985. Planktonic foraminifera and oxygen isotope stratigraphy of CESAR cores 102 and 103; preliminary results. In Jackson, H. R., Mudie, P. J., and Blasco, S. M. (Eds.), Initial geological report on CESAR-the Canadian expedition to study the Alpha Ridge, Arctic Ocean. Geol. Surv. Can. Pap., 84-22:11:-124.

Aksu, A. E., and Mudie, P. J., 1985. Magnetic stratigraphy and palynology demonstrate at least 4 million years of Arctic Ocean sedimentation. Nature, 318:280-283.

Belanger, P. E., 1982. Paleoceanography of the Norwegian Sea during the past 130.000 yrs: coccolithophorid and foraminiferal data. Boreas, 11:26-39.

Belanger, P. E., and Streeter, S. S, 1980. Distribution and ecology of benthic foraminifera in the Norwegian-Greenland Sea. Mar. Micropaleontol., 5:401-428.

Berger, A., Imbrie, J., Hays, J., Kukla, G., Saltzman, B. (Eds.), 1984. Milankovitch and Climate, NATO ASI Series C: Mathematical and Physical Sciences, 126, Pts. 1 and 2: Dodrecht (Reidel Publishing Co.).

Berger, W. H., 1968. Planktonic foraminifera: selective dissolution and paleoclimatic interpretation. Deep Sea Res., 15, 31-43.

Berger, W. H., 1971. Sedimentation of planktonic foraminifera. Mar. Geol., 11, 325-358.

Berger, W. H., and Vincent, E., 1986. Sporadic shutdown of North Atlantic deep water production during the Glacial-Holocene transition? Nature, 324:53-55.

Clark, D. L., and Hanson, A., 1983. Central Arctic Ocean sediment texture: A key to ice transport mechanisms. In Molnia, B. F., (Ed), Glacial-Marine Sedimentation: New York (Plenum Press), 301-330.

Clark, D. L., Andree, M., Broecker, W. S., Mix, A. C., Bonani, G, Hofman, H. J., Morenzoni, E., Nessi, M., Suter, M., and Woelfli, W., in press. Arctic Ocean chronology confirmed by accelerator ${ }^{14} \mathrm{C}$ dating. Geophys. Res. Lett.

CLIMAP project members, 1976. The Surface of the Ice-Age Earth. Science, 191, 1131-1137.

CLIMAP, 1981. Maps of Northern and Southern Hemisphere continental ice, sea ice, and sea surface temperatures in August for the modern and the last glacial maximum. Geol. Soc. Am. Map and Chart Ser., MC-3G.

Crowley, T. J., 1983. Calcium carbonate preservation patterns in the North Atlantic during the last 150.000 years. Mar. Geol., 51, 1-14.

Ehrmann, W. H., and Thiede, J., 1985. History of Mesozoic and Cenozoic Sediment fluxes to the North Atlantic Ocean. Contrib. Sedimentol., 15:121-144.

Eldholm, O., Thiede, J., Taylor, E. et al., 1987. Proc. ODP, Init. Repts., 104: College Station, TX (Ocean Drilling Program).

Einarsson, T., Hopkins, D. M., and Doell, R. R., 1967. The stratigraphy of Tjörnes, Northern Iceland, and the history of the Bering Land Bridge. In Hopkins, D. M. (Ed.), The Barents Land Bridge: Stanford, CA (Stanford University Press, 312-325.

Gorshkova, T. I., 1960. Sediments of the Norwegian Sea. In Proc. Int. Geol. Congr. 21st, Submar. Geol., 10:16-22.

Hald, M., and Vorren, T. O., 1987. Foraminiferal stratigraphy and environment of late Weichselian deposits on the continental shelf off Troms $\varnothing$, northern Norway. Mar. Micropaleontol., 112:129-160.

Hald, M., and Vorren, T. O., 1987. Stable isotope stratigraphy and paleoceanography during the last deglaciation on the continental shelf off Tromsø, Northern Norway. Paleoceanography, 2/6, 583-599.

Henrich, R., 1986. A calcite dissolution pulse in the Norwegian-Greenland Sea during the last deglaciation. Geol. Rundsch., 75:805-827.

Henrich, R., Kassens, H., Vogelsang, E., and Thiede, J., in press. Sedimentary facies of glacial/interglacial cycles in the Norwegian Sea during the last $350 \mathrm{Ky}$. Mar. Geol. 
Henrich, R., and Wefer, G., 1986. Dissolution of biogenic carbonates: effects of skeletal structure. Mar. Geol., 70:341-362.

Herterich, K., and Sarnthein, M., 1984. Brunhes time scale: tuning birates of calcium carbonate dissolution and cross spectral analyses with solar insolation. In Berger, L. A., et al. (Eds.), Milanchovitch and Climate, Part 1: Amsterdam (D. Reidel Publishing Co.), 447466.

Holtedahl, H., and Bjerkli, K., 1975. Pleistocene and Recent sediments of the Norwegian Continental Shelf $\left(62^{\circ} \mathrm{N}-71^{\circ} \mathrm{N}\right)$, and the Norwegian Channel area. Norges. Geol. Unders., 316:241-252.

Imbrie, N., and Kipp, N. G., 1971. A new micropaleontologic method for quantitative paleoclimatology: Application to a late Pleistocene Carribean core. In Turekian, K. K. (Ed.), Late Cenozoic Glacial Ages: New Haven, CT (Yale University Press), 71-147.

Imbrie, J., Hays, J. D., Martinson, D. G., McIntyre, A., Mix, A. C., Morley, J. J., Pisias, N. G., Prell, W. L., and Shackleton, N. J., 1984. The orbital theory of Pleistocene climate: Support from a revised chronology of the marine $\delta^{18} 0$ record. In Berger, A. L., et al. (Eds.), Milankovitch and Climate, Part I: Amsterdam (D. Reidel Publishing Co.), 269-305.

Jansen, E., Sejrup, H. P., Fjaeran, T., Hald, M., Holtedahl, H., and Skarbø, O., 1983. Late Weichselian paleoceanography of the southeastern Norwegian Sea. Norsk Geol. Tidsskr., 63, 117-146.

Jansen, E., and Erlenkeuser, H., 1985. Ocean circulation in the Norwegian Sea during the last deglaciation: Isotopic evidence. Palaeogeogr., Palaeoclimatol., Palaeoecol., 49, 189-206.

Jansen, E., and Bjørklund, K., 1985. Surface ocean circulation in the Norwegian Sea 15.000 B.P. to present. Boreas, 14:243-257.

Jansen, E., and Sejrup, H. P., 1986. Stable isotope stratigraphy and amino-acid epimerization for the last $2.4 \mathrm{ma}$. at Site 610 , Holes 610 and 610A. In Ruddiman, W. F., Kidd, R. B., Thomas, E., et al., Init. Repts. DSDP, 94, Pt. 2: Washington (U.S. Govt. Printing Office), 879-888.

Jansen, E., Bleil, U., Henrich, R., Kringstad, L. and Slettemark, B., in press. Paleoenvironmental changes in the Norwegian Sea and the northeast Atlantic during the last $2.8 \mathrm{Ma}$ : ODP/DSDP Sites 610, 642, 643 and 644. Paleoceanography.

Johannessen, O. M., 1986. Brief overview of the physical oceanography. In Hurdle, B. G. (Ed.), The Nordic Seas: New York (Springer Verlag), 103-127.

Kellogg, T. B., 1975. Late Quaternary climatic changes in the Norwegian-Greenland sea. In Bowling, S. A., and Weller, G. (Eds.) Climate of the Arctic: College, AK (University of Alaska), 3-36.

Kellogg, T. B., 1976. Late Quaternary climatic changes: Evidence from deep-sea cores of Norwegian and Greenland Seas. In Cline, R. M. and Hays, J. E. (Eds.), Investigation of Late Quaternary Paleoceanography and Paleoclimatology. Geol. Soc. Am. Mem., 145, 77-110.

Kellogg, T. B., 1977. Paleoclimatology and paleoceanography of the Norwegian-Greenland Seas: the last 450,000 years. Mar. Micropaleontol., 2:235-249.

Kellogg, T. B., 1980. Paleoclimatology and Paleoceanography of the Norwegian-Greenland sea: Glacial-interglacial contrasts. Boreas, 9, 115-137.

Kellogg, T. B., Duplessy, J. C., and Shackleton, N. J., 1978. Planktonic foraminiferal and oxygen isotopic stratigraphy and paleoclimatology of the Norwegian Sea deep sea cores. Boreas, 7, 61-73.

Kennett, J., and Srinivasan, M. S., 1980. Surface ultrastructural variation in Neogloboquadrina pachyderma (Ehrenberg): phenotypic variation and phylogeny in the late Cenozoic. Cushman Foundation Spec. Publ. 19:134-162.

King, L. H., Rokoengen, K., and Gunleiksrud, T., 1987. Quaternary seismostratigraphy of the Mid Norwegian Shelf, $65^{\circ}-67^{\circ} 30^{\prime} \mathrm{N}$. - A till tongue stratigraphy. IKU Publ. 114.

Marquard, R. S., and Clark, D. L., 1987. Pleistocene paleoceanographic correlations: northern Greenland Sea to central Arctic Ocean. Mar. Micropaleontol., 12, 325-341.

Meincke, J., 1983. The modern current regime across the GreenlandScotland Ridge. In Bott, H. P., Saxov, S., Talwani, M., and Thiede, J. (Eds.), Structure and development of the Greenland-Scotland Ridge, Nato Conference Series: New York (Plenum Press), 637-650.

Minicucci, D. A., and Clark, D. L., 1983. A late Cenozoic stratigraphy for glacial-marine sediments of the eastern Alpha Cordillera, central Arctic Ocean. In Molnia, B. F. (Ed.), Glacial-Marine Sedimentation: New York (Plenum Press), 331-365.
Molnia, B. F., 1983. Distal Glacial-Marine Sedimentation: Abundance, composition, and distribution of North-Atlantic Ocean Pleistocene ice-rafted sediment. In Molnia, B. F. (Ed.), Glacial Marine Sedimentation: New York (Plenum Press), 593-626.

Powell, R. D., 1983. Glacial-Marine Sedimentation processes and lithofacies of temperate tidewater glaciers, Glacier Bay, Alaska. In Molnia, B. F., (Ed.), Glacial-Marine Sedimentation. New York (Plenum Press), 185-231.

Raymo, M. E., Ruddiman, W. F., and Clement, B. M., 1986. PliocenePleistocene paleoceanography of the North Atlantic at Deep Sea Drilling Project Site 609. In Ruddiman, W. F., Kidd, R. D., et al., Init. Repts. DSDP, 94, Pt. 2, 895-902.

Reynolds, L. A. and Thunell, R. C., 1986. Seasonal production and morphologic variation of Neogloboquadrina pachyderma (Ehrenberg) in the northeast Pacific. Micropaleontology, 32:1-18.

Rokoengen, K., Gunleiksrud, T., Lien, R. L., Løfaldi, M., Rise, L., Sindre, E., and Vigram, J. O., 1980. Shallow geology on the continental shelf off Møre and Romsdal. Description of the 1:250000 Quaternary geological map 6203. IKU Rep. 105:1-49.

Rokoengen, K., and Saettem, J., 1983. Shallow bedrock geology and Quaternary thickness off northern Helgeland, Vestfjorden, and Lofoten. IKU Rep. P155:1-44.

Ruddiman, W. F, and Glover, L. K., 1975. Subpolar North Atlantic Circulation at $9300 \mathrm{yr}$ B.P.: faunal evidence. Quat. Res., 5:361-389.

Ruddiman, W. F., and McIntyre, A., 1977. Late Quaternary surface ocean kinematics and climatic change in the high-Latitude North Atlantic. J. Geophys. Res. B2:3877-3887.

Ruddiman, W. F., and McIntyre, A., 1981a. The North Atlantic Ocean during the last deglaciation. Palaeogeogr., Palaeoclimatol., Palaeoecol., 35:145-214.

Ruddiman, W. F., and McIntyre, A., 1981b. Oceanic mechanisms for amplification of the 23,000-year ice-volume cycle. Science, 212:617-627.

Ruddiman, W. F., and McIntyre, A., 1984. An evaluation of ocean-climate theories on the North Atlantic. In Berger, A., Imbrie, J., Hays, J., Kukla, G., and Salzman, B. (Eds.). Milankovitch and Climate, Part 2: Dordrecht (D.Riedel Publishing Co.), 671-686.

Ruddiman, W. F., Raymo, M., and McIntyre, A., 1986a. Matuyama 41,000-year cycles: North Atlantic Ocean and Northern Hemisphere ice sheets. Earth Planet. Sci. Lett., 80:117-129.

Ruddiman, W. F., McIntyre, A., and Raymo, M., 1986b. Paleoenvironmental results from North Atlantic Sites 607 and 609. In Ruddiman, W. F., Kidd, R. B., et al., Init. Repts. DSDP, 94, Pt. 2: Washington (U.S. Govt. Printing Office), 855-878.

Ruddiman, W. F., Kidd, R. B., et al., 1986. Init. Repts. DSDP, 94, Pt. 2: Washington (U.S. Govt. Printing Office).

Sarynina, R. N., 1972. Conditions of origin of cold deep-sea waters in the Bear Islands channel. In Lee, A. J., and Charnock, H., (Eds.), Proc. Symposium, Dublin, Ireland, 25-27 Sept. 1969: Copenhagen (International council for the exploration of the Sea).

Sarnthein, M., and Stremme, H. E., 1984. The Holstein interglaciation: Time-stratigraphic position and correlation to stable-isotope stratigraphy of deep-sea sediments. Quat. Res., 26:283-298.

Seibold, E. and Berger, W. H., 1970. The Sea Floor: New York: (Springer Verlag).

Sejrup, H. P., Jansen, E., Erlenkeuser, H., and Holtedahl, H., 1984. New faunal and isotopic evidence on the late Weichselian-Holocene oceanographic changes in the Norwegian sea. Quat. Res., 21:74-84.

Shackleton, N. J., et al., 1984. Oxygen isotope calibration of the onset of ice-rafting and history of glaciation in the northeast Atlantic. $\mathrm{Na}$ ture, 307:620.

Srivastava, S., Arthur, M, et al., 1987. Proc. ODP, Init. Repts., 105: College Station, TX (Ocean Drilling Program).

Streeter, S. S., Belanger, P. E., Kellogg, T. B., and Duplessy, J. C., 1982. Late Pleistocene paleoceanography of the Norwegian-Greenland Sea: Benthic foraminiferal evidence. Quat. Res., 18, 72-90.

Swift, J. H., 1986. The Arctic Waters. In Hurdle, B. A. (Ed.), The Nordic Seas 129-154.

Vogt, P. R., 1986. The present accreting plate boundary west of the North America Plate. In Vogt, P. R., and Tucholke, B. E. (Eds.), The Western North Atlantic Region. Vol. M, Decade of North American Geology (DNAG) series: Boulder, CO (Geological Society of America).

Vorren, T., Hald, M, and Thomsen, E., 1984. Quaternary sediments and environments on the continental shelf off northern Norway. Mar. Geol., 57:229-257. 
Wohlfeil, K., 1982. Verbreitung, Herkunft, und Bedeutung der Psephite des Seegebietes zwischen den Färoer und Island. "Meteor" Forschungsergeb., C36:31-56.

Wohlfeil, K., 1983. Verteilung und Herkunft der Sedimente in Lotkernen von der Island-Färöer-Schwelle (Nordatlantik). Geol. Rundschau, 72:137-165.
Worthington, L. V., 1970. The Norwegian sea as a mediterranean basin. Deep Sea Res., 12:667-676.

Date of initial receipt: 15 July 1987

Date of acceptance: 10 May 1988

Ms 104B-116

APPENDIX

\section{CARBONATE/ORGANIC CARBON/COARSE FRACTIONS}

Table A1. Carbonate/organic carbon/coarse-fraction contents, Hole 642B.

\begin{tabular}{|c|c|c|c|c|c|c|}
\hline Sample & $\begin{array}{l}\text { Depth } \\
\text { (mbsf) }\end{array}$ & $\begin{array}{l}\% \text { Coarse } \\
\text { fraction }\end{array}$ & $\%$ TOC & $\begin{array}{l}\% \text { Carb. } \\
\text { bulk }\end{array}$ & $\begin{array}{l}\% \text { Carb. } \\
>63 \mu \mathrm{m}\end{array}$ & $\begin{array}{l}\% \text { Carb. } \\
<63 \mu \mathrm{m}\end{array}$ \\
\hline \multicolumn{7}{|l|}{ Hole 642B } \\
\hline $1 \mathrm{H}-1-96$ & 0.98 & 13.93 & 0.28 & 10.76 & 2.02 & 8.74 \\
\hline $1 \mathrm{H}-2-40$ & 1.92 & 6.05 & 0.26 & 7.64 & 1.07 & 6.57 \\
\hline $1 \mathrm{H}-3-40$ & 3.42 & 12.57 & 0.34 & 6.18 & 1.76 & 4.42 \\
\hline $1 \mathrm{H}-3-96$ & 3.98 & 19.45 & 0.20 & 11.56 & 3.95 & 7.61 \\
\hline $2 \mathrm{H}-1-112$ & 5.94 & 11.38 & 0.24 & 9.66 & 3.36 & 6.30 \\
\hline $2 \mathrm{H}-2-53$ & 6.85 & 7.65 & 0.24 & 10.30 & 3.33 & 6.97 \\
\hline $2 \mathrm{H}-2-112$ & 7.44 & 11.60 & 0.24 & 7.60 & 1.00 & 6.60 \\
\hline $2 \mathrm{H}-3-53$ & 8.35 & 16.24 & 0.30 & 19.81 & 11.13 & 8.68 \\
\hline $2 \mathrm{H}-3-112$ & 8.94 & 8.36 & 0.31 & 5.68 & 0.53 & 5.15 \\
\hline $2 \mathrm{H}-4-53$ & 9.85 & 12.35 & 0.33 & 7.27 & 2.77 & 4.50 \\
\hline $2 \mathrm{H}-4-112$ & 10.44 & 12.05 & 0.23 & 4.81 & 0.25 & 4.56 \\
\hline $2 \mathrm{H}-5-53$ & 11.35 & 9.85 & 0.27 & 10.83 & 4.82 & 6.01 \\
\hline $2 \mathrm{H}-6-53$ & 12.85 & 9.65 & 0.46 & 5.16 & 0.82 & 4.34 \\
\hline $3 \mathrm{H}-1-44$ & 14.76 & 8.12 & 0.28 & 16.30 & 2.61 & 13.69 \\
\hline $3 \mathrm{H}-2-106$ & 16.88 & 12.05 & 0.24 & 10.87 & 0.06 & 10.81 \\
\hline $3 \mathrm{H}-3-44$ & 17.76 & 5.95 & 0.29 & 9.11 & 0.10 & 9.01 \\
\hline $3 \mathrm{H}-3-106$ & 18.38 & 7.11 & 0.28 & 9.70 & 0.75 & 8.95 \\
\hline $3 \mathrm{H}-4-44$ & 19.26 & 2.93 & 0.26 & 22.83 & 4.08 & 18.75 \\
\hline $3 \mathrm{H}-4-106$ & 19.88 & 3.37 & 0.26 & 30.30 & 0.29 & 30.01 \\
\hline $4 \mathrm{H}-1-43$ & 21.13 & 10.84 & 0.46 & 6.56 & 0.68 & 5.88 \\
\hline $4 \mathrm{H}-1-113$ & 21.70 & 15.07 & 0.36 & 6.69 & 1.26 & 5.43 \\
\hline $4 \mathrm{H}-2-43$ & 22.57 & 14.21 & 0.44 & 7.08 & 1.06 & 6.02 \\
\hline $4 \mathrm{H}-3-43$ & 24.01 & 8.03 & 0.32 & 5.61 & 0.42 & 5.19 \\
\hline $4 \mathrm{H}-3-113$ & 24.68 & 21.01 & 0.42 & 12.27 & 6.13 & 6.14 \\
\hline $4 \mathrm{H}-4-43$ & 25.44 & 6.68 & 0.38 & 3.40 & 1.16 & 2.24 \\
\hline $4 \mathrm{H}-5-43$ & 26.88 & 25.40 & 0.53 & 1.61 & 0.56 & 1.05 \\
\hline $4 \mathrm{H}-5-113$ & 27.56 & 3.56 & 1.02 & 10.65 & 1.96 & 8.69 \\
\hline $4 \mathrm{H}-6-113$ & 28.99 & 12.76 & 0.50 & 6.69 & 0.43 & 6.26 \\
\hline $5 \mathrm{H}-1-33$ & 29.72 & 14.14 & 0.39 & 6.19 & 0.27 & 5.92 \\
\hline $5 \mathrm{H}-1-99$ & 30.34 & 4.14 & 0.45 & 9.51 & 0.77 & 8.74 \\
\hline $5 \mathrm{H}-2-33$ & 31.11 & 3.81 & 0.41 & 10.45 & 0.57 & 9.88 \\
\hline $5 \mathrm{H}-3-33$ & 32.00 & 21.21 & 0.49 & 0.90 & 0.20 & 0.70 \\
\hline $5 \mathrm{H}-3-99$ & 33.12 & 5.54 & 0.28 & 4.50 & 0.81 & 3.69 \\
\hline $5 \mathrm{H}-4-33$ & 33.89 & 30.74 & 0.17 & 13.29 & 4.52 & 8.77 \\
\hline $5 \mathrm{H}-4-99$ & 34.51 & 15.05 & 0.25 & 1.98 & 0.14 & 1.84 \\
\hline $5 \mathrm{H}-5-33$ & 35.29 & 5.86 & 0.30 & 2.66 & 1.25 & 1.41 \\
\hline $5 \mathrm{H}-5-99$ & 35.90 & 5.17 & 0.21 & 4.49 & 0.47 & 4.02 \\
\hline $5 \mathrm{H}-6-33$ & 36.68 & 5.89 & 0.31 & 8.72 & 1.37 & 7.35 \\
\hline $5 \mathrm{H}-6-99$ & 37.29 & 8.02 & 0.21 & 9.99 & 2.95 & 7.04 \\
\hline $5 \mathrm{H}-7-99$ & 38.68 & 20.89 & 0.29 & 6.27 & 0.54 & 5.73 \\
\hline $6 \mathrm{H}-1-35$ & 39.27 & 13.32 & 0.25 & 2.88 & 0.64 & 2.24 \\
\hline $6 \mathrm{H}-1-104$ & 39.96 & 10.84 & 1.13 & 3.60 & 2.52 & 1.08 \\
\hline $6 \mathrm{H}-2-133$ & 41.75 & 19.73 & 0.31 & 0.00 & 0.00 & 0.00 \\
\hline $6 \mathrm{H}-3-31$ & 42.33 & 15.74 & 0.77 & 0.00 & 0.00 & 0.00 \\
\hline $6 \mathrm{H}-3-119$ & 43.11 & 8.66 & 0.24 & 0.00 & 0.00 & 0.00 \\
\hline $6 \mathrm{H}-4-11$ & 43.53 & 11.78 & 0.90 & 0.71 & 0.15 & 0.56 \\
\hline $6 \mathrm{H}-4-92$ & 44.34 & 7.95 & 0.31 & 1.07 & 0.86 & 0.21 \\
\hline $6 \mathrm{H}-5-34$ & 45.26 & 6.64 & 0.26 & 0.39 & 0.05 & 0.66 \\
\hline $6 \mathrm{H}-5-121$ & 46.13 & 12.03 & 1.08 & 0.00 & 0.00 & 0.00 \\
\hline $6 \mathrm{H}-6-6$ & 46.47 & 2.28 & 0.28 & 0.00 & 0.00 & 0.00 \\
\hline $6 \mathrm{H}-6-57$ & 46.99 & 20.17 & 0.35 & 0.53 & 0.53 & 0.00 \\
\hline $7 \mathrm{H}-1-51$ & 47.91 & 2.84 & 0.32 & 0.00 & 0.00 & 0.00 \\
\hline $7 \mathrm{H}-1-131$ & 48.68 & 15.43 & 0.61 & 0.00 & 0.00 & 0.00 \\
\hline $7 \mathrm{H}-2-20$ & 49.05 & 14.47 & 0.25 & 1.14 & 0.25 & 0.89 \\
\hline $7 \mathrm{H}-2-131$ & 50.11 & 5.95 & 0.77 & 3.51 & 0.69 & 2.82 \\
\hline $7 \mathrm{H}-3-20$ & 50.49 & 15.57 & 1.02 & 0.00 & 0.00 & 0.00 \\
\hline $7 \mathrm{H}-3-131$ & 51.55 & 13.99 & 0.30 & 0.00 & 0.00 & 0.00 \\
\hline $7 \mathrm{H}-4-15$ & 51.88 & 12.64 & 0.31 & 1.00 & 0.73 & 0.27 \\
\hline $7 \mathrm{H}-4-105$ & 52.74 & 18.91 & 1.51 & 0.00 & 0.00 & 0.00 \\
\hline $7 \mathrm{H}-5-41$ & 53.56 & 5.50 & 0.31 & 0.00 & 0.00 & 0.00 \\
\hline
\end{tabular}


Table A1 (continued).

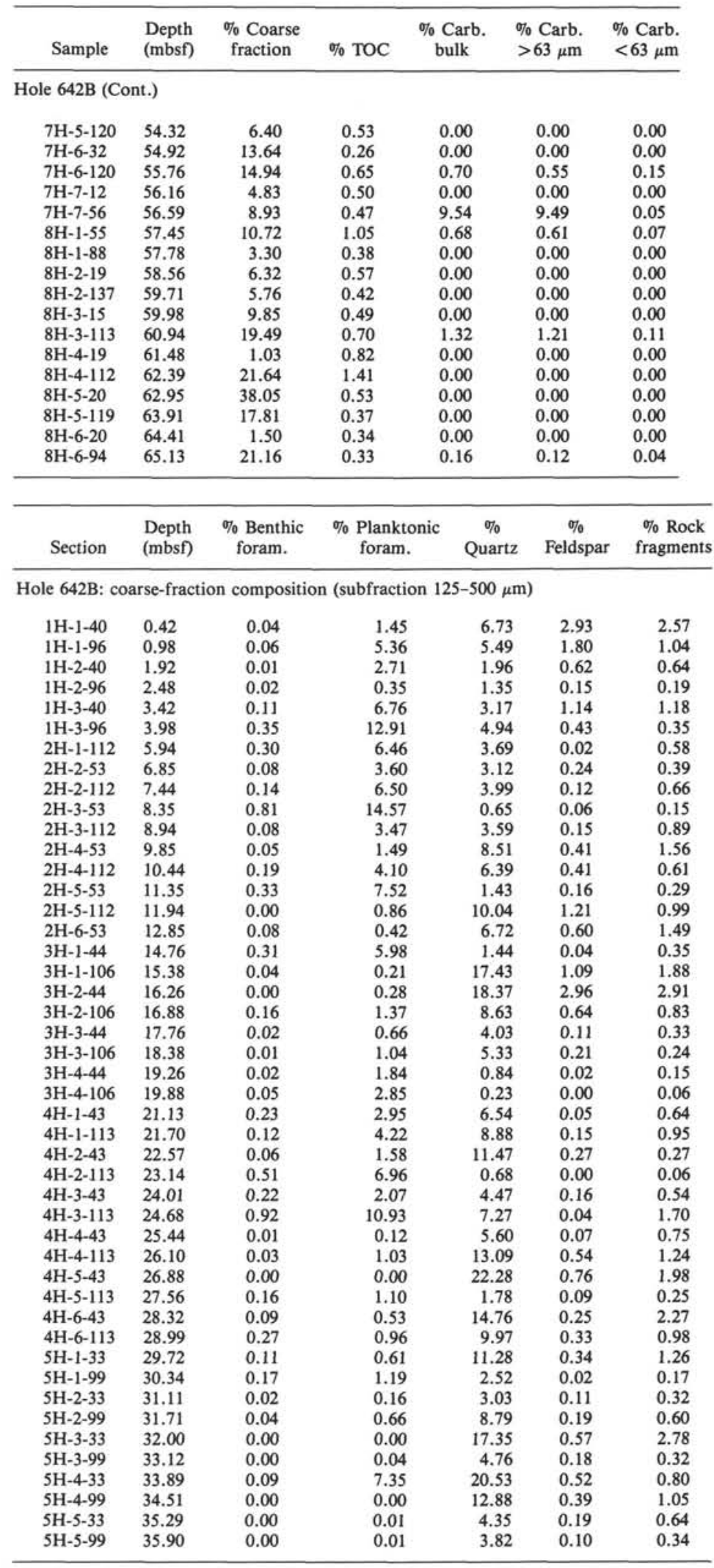


Table A1 (continued).

\begin{tabular}{|c|c|c|c|c|c|c|}
\hline Section & $\begin{array}{l}\text { Depth } \\
\text { (mbsf) }\end{array}$ & $\begin{array}{c}63-125 \\
\mu \mathrm{m}\end{array}$ & $\begin{array}{c}125-250 \\
\mu \mathrm{m}\end{array}$ & $\begin{array}{c}250-500 \\
\mu \mathrm{m}\end{array}$ & $\begin{array}{c}500-1000 \\
\mu \mathrm{m}\end{array}$ & $\begin{array}{c}>1000 \\
\mu \mathrm{m}\end{array}$ \\
\hline \multicolumn{7}{|c|}{ Hole $642 \mathrm{~B}$ coarse-fraction: weight percentages of subfractions } \\
\hline $1 \mathrm{H}-1-40$ & 0.42 & 48.91 & 27.09 & 10.02 & 7.02 & 6.96 \\
\hline $1 \mathrm{H}-1-96$ & 0.98 & 38.95 & 35.29 & 10.46 & 3.99 & 11.31 \\
\hline $1 \mathrm{H}-2-40$ & 1.92 & 51.81 & 32.31 & 9.36 & 4.29 & 2.23 \\
\hline $1 \mathrm{H}-2-96$ & 2.48 & 45.86 & 30.45 & 7.03 & 6.04 & 10.62 \\
\hline $1 \mathrm{H}-3-40$ & 3.42 & 54.15 & 34.72 & 5.82 & 2.55 & 2.77 \\
\hline $1 \mathrm{H}-3-96$ & 3.98 & 36.21 & 44.67 & 8.20 & 2.02 & 8.90 \\
\hline $2 \mathrm{H}-1-112$ & 5.94 & 44.91 & 38.95 & 11.04 & 2.84 & 2.26 \\
\hline $2 \mathrm{H}-2-53$ & 6.85 & 52.39 & 33.22 & 9.62 & 2.03 & 2.74 \\
\hline $2 \mathrm{H}-2-112$ & 7.44 & 40.58 & 45.74 & 11.40 & 1.23 & 1.05 \\
\hline $2 \mathrm{H}-3-53$ & 8.35 & 23.45 & 69.52 & 6.81 & 0.22 & 0.00 \\
\hline $2 \mathrm{H}-3-112$ & 8.94 & 53.72 & 35.76 & 7.37 & 1.81 & 1.34 \\
\hline $2 \mathrm{H}-4-53$ & 9.85 & 48.50 & 34.90 & 9.96 & 2.20 & 4.45 \\
\hline $2 \mathrm{H}-4-112$ & 10.44 & 46.22 & 35.69 & 9.14 & 3.46 & 5.49 \\
\hline $2 \mathrm{H}-5-53$ & 11.35 & 36.93 & 52.02 & 8.56 & 1.70 & 0.78 \\
\hline $2 \mathrm{H}-5-112$ & 11.94 & 55.46 & 28.22 & 10.14 & 4.76 & 1.43 \\
\hline $2 \mathrm{H}-6-53$ & 12.85 & 53.20 & 27.77 & 8.93 & 3.45 & 6.65 \\
\hline $3 \mathrm{H}-1-44$ & 14.76 & 51.94 & 42.83 & 4.60 & 0.63 & 0.00 \\
\hline $3 \mathrm{H}-1-106$ & 15.38 & 38.86 & 32.61 & 11.89 & 5.01 & 11.63 \\
\hline $3 \mathrm{H}-2-44$ & 16.26 & 43.03 & 31.99 & 12.46 & 5.48 & 7.04 \\
\hline $3 \mathrm{H}-2-106$ & 16.88 & 46.41 & 30.28 & 12.55 & 5.24 & 5.51 \\
\hline $3 \mathrm{H}-3-44$ & 17.76 & 76.22 & 17.50 & 4.86 & 1.26 & 0.16 \\
\hline $3 \mathrm{H}-3-106$ & 18.38 & 34.23 & 26.02 & 12.96 & 3.66 & 23.12 \\
\hline $3 \mathrm{H}-4-44$ & 19.26 & 55.11 & 38.64 & 4.67 & 1.58 & 0.00 \\
\hline $3 \mathrm{H}-4-106$ & 19.88 & 58.97 & 35.32 & 4.41 & 1.30 & 0.00 \\
\hline $4 \mathrm{H}-1-43$ & 21.13 & 54.53 & 31.26 & 6.16 & 1.57 & 6.48 \\
\hline $4 \mathrm{H}-1-113$ & 21.70 & 41.11 & 23.34 & 4.46 & 1.50 & 29.60 \\
\hline $4 \mathrm{H}-2-43$ & 22.57 & 47.13 & 31.78 & 12.57 & 5.63 & 2.89 \\
\hline $4 \mathrm{H}-2-113$ & 23.14 & 35.79 & 55.24 & 5.27 & 1.18 & 2.51 \\
\hline $4 \mathrm{H}-3-43$ & 24.01 & 58.83 & 33.25 & 5.67 & 1.73 & 0.52 \\
\hline $4 \mathrm{H}-3-113$ & 24.68 & 45.27 & 46.19 & 6.20 & 1.68 & 0.65 \\
\hline $4 \mathrm{H}-4-43$ & 25.44 & 54.49 & 30.41 & 8.76 & 2.14 & 4.21 \\
\hline $4 \mathrm{H}-4-113$ & 26.10 & 60.67 & 26.55 & 7.59 & 2.63 & 2.55 \\
\hline $4 \mathrm{H}-5-43$ & 26.88 & 36.46 & 33.94 & 19.04 & 6.36 & 4.20 \\
\hline $4 \mathrm{H}-5-113$ & 27.56 & 46.63 & 27.99 & 13.80 & 7.53 & 4.05 \\
\hline $4 \mathrm{H}-6-43$ & 28.32 & 54.15 & 34.34 & 5.97 & 2.47 & 3.07 \\
\hline $4 \mathrm{H}-6-113$ & 28.99 & 64.78 & 28.51 & 4.54 & 1.15 & 1.02 \\
\hline $5 \mathrm{H}-1-33$ & 29.72 & 54.37 & 26.17 & 8.66 & 3.86 & 6.94 \\
\hline $5 H-1-99$ & 30.34 & 46.33 & 38.09 & 11.34 & 4.24 & 0.00 \\
\hline $5 \mathrm{H}-2-33$ & 31.11 & 50.96 & 28.36 & 5.52 & 12.00 & 3.16 \\
\hline $5 \mathrm{H}-2-99$ & 31.71 & 41.79 & 30.58 & 14.45 & 2.65 & 10.53 \\
\hline $5 \mathrm{H}-3-33$ & 32.00 & 45.55 & 30.65 & 9.63 & 3.71 & 10.46 \\
\hline $5 \mathrm{H}-3-99$ & 33.12 & 66.00 & 27.07 & 5.37 & 1.18 & 0.38 \\
\hline $5 \mathrm{H}-4-33$ & 33.89 & 61.49 & 32.12 & 3.33 & 0.94 & 2.11 \\
\hline $5 \mathrm{H}-4-99$ & 34.51 & 66.53 & 27.49 & 4.55 & 0.78 & 0.66 \\
\hline $5 \mathrm{H}-5-33$ & 35.29 & 57.68 & 27.95 & 7.94 & 2.99 & 3.43 \\
\hline $5 \mathrm{H}-5-99$ & 35.90 & 71.03 & 18.00 & 6.12 & 2.55 & 2.29 \\
\hline $5 \mathrm{H}-6-33$ & 36.68 & 48.37 & 38.01 & 8.81 & 2.31 & 2.50 \\
\hline $5 \mathrm{H}-6-99$ & 37.29 & 42.39 & 41.89 & 9.58 & 2.26 & 3.89 \\
\hline $5 \mathrm{H}-7-33$ & 38.07 & 71.68 & 18.87 & 6.78 & 1.22 & 1.44 \\
\hline $5 \mathrm{H}-7-99$ & 38.68 & 74.21 & 22.51 & 2.72 & 0.56 & 0.00 \\
\hline $6 \mathrm{H}-1-35$ & 39.27 & 79.73 & 15.96 & 3.33 & 0.94 & 0.04 \\
\hline $6 \mathrm{H}-1-104$ & 39.96 & 56.30 & 27.83 & 7.05 & 3.80 & 5.02 \\
\hline Section & $\begin{array}{l}\text { Depth } \\
\text { (mbsf) }\end{array}$ & $\begin{array}{c}\% \text { Benth } \\
\text { foram. }\end{array}$ & $\begin{array}{l}\% \mathrm{Pla} \\
\mathrm{fo}\end{array}$ & $\begin{array}{l}\text { ktonic } \\
\text { am. }\end{array}$ & $\begin{array}{c}\% \\
\text { Quartz }\end{array}$ & $\begin{array}{l}\% \\
\text { dspar }\end{array}$ \\
\hline
\end{tabular}

Hole 642B : Coarse-fraction composition (subfraction $125 \mu \mathrm{m}-500 \mu \mathrm{m}$ )

$\begin{array}{llllrll}5 \mathrm{H}-6-33 & 36.68 & 0.01 & 1.76 & 3.45 & 0.17 & 0.17 \\ 5 \mathrm{H}-6-99 & 37.29 & 0.08 & 4.07 & 3.25 & 0.09 & 0.26 \\ 5 \mathrm{H}-7-33 & 38.07 & 0.05 & 0.05 & 3.07 & 0.06 & 0.16 \\ 5 \mathrm{H}-7-99 & 38.68 & 0.02 & 0.23 & 17.15 & 0.46 & 0.50 \\ 6 \mathrm{H}-1-35 & 39.27 & 0.05 & 0.39 & 10.32 & 0.61 & 0.72 \\ 6 \mathrm{H}-1-104 & 39.96 & 0.00 & 0.00 & 7.90 & 0.57 & 1.94 \\ 6 \mathrm{H}-2-54 & 40.96 & 0.07 & 0.02 & 6.37 & 0.52 & 0.34 \\ 6 \mathrm{H}-2-133 & 41.75 & 0.00 & 0.00 & 15.98 & 1.18 & 2.15 \\ 6 \mathrm{H}-3-31 & 42.33 & 0.00 & 0.00 & 11.99 & 0.82 & 2.53 \\ 6 \mathrm{H}-3-119 & 43.11 & 0.00 & 0.00 & 6.48 & 0.45 & 0.49 \\ 6 \mathrm{H}-4-11 & 43.53 & 0.00 & 0.00 & 8.30 & 0.70 & 2.19 \\ 6 \mathrm{H}-4-92 & 44.34 & 0.00 & 0.00 & 6.22 & 0.44 & 0.67 \\ 6 \mathrm{H}-5-34 & 45.26 & 0.00 & 0.00 & 4.95 & 0.40 & 0.40 \\ 6 \mathrm{H}-5-121 & 46.13 & 0.04 & 0.00 & 10.27 & 0.08 & 1.49 \\ 6 \mathrm{H}-6-6 & 46.47 & 0.01 & 0.00 & 1.84 & 0.05 & 0.12 \\ 6 \mathrm{H}-6-57 & 46.99 & 0.04 & 0.00 & 18.52 & 0.44 & 0.52 \\ 7 \mathrm{H}-1-51 & 47.91 & 0.00 & 0.00 & 2.40 & 0.08 & 0.07\end{array}$


Table A1 (continued).

\begin{tabular}{|c|c|c|c|c|c|c|}
\hline Section & $\begin{array}{l}\text { Depth } \\
\text { (mbsf) }\end{array}$ & $\begin{array}{l}\% \text { Benthic } \\
\text { foram. }\end{array}$ & $\begin{array}{l}\% \text { Planktonic } \\
\text { foram. }\end{array}$ & $\begin{array}{c}\% \\
\text { Quartz }\end{array}$ & $\begin{array}{c}\% \\
\text { Feldspar }\end{array}$ & $\begin{array}{c}\% \text { Rock } \\
\text { fragments }\end{array}$ \\
\hline \multicolumn{7}{|c|}{ Hole 642B: coarse-fraction composition (subfraction $125 \mu \mathrm{m}-500 \mu \mathrm{m}$ ) (Cont.) } \\
\hline $7 \mathrm{H}-1-131$ & 48.68 & 0.00 & 0.00 & 14.29 & 0.05 & 0.99 \\
\hline $7 \mathrm{H}-2-20$ & 49.05 & 0.07 & 0.00 & 13.10 & 0.20 & 0.87 \\
\hline $7 \mathrm{H}-2-131$ & 50.11 & 0.08 & 0.49 & 4.58 & 0.08 & 0.54 \\
\hline $7 \mathrm{H}-3-20$ & 50.49 & 0.00 & 0.05 & 14.59 & 0.12 & 0.08 \\
\hline $7 \mathrm{H}-3-131$ & 51.55 & 0.00 & 0.04 & 13.18 & 0.11 & 0.32 \\
\hline $7 \mathrm{H}-4-15$ & 51.88 & 0.00 & 0.00 & 11.86 & 0.13 & 0.44 \\
\hline $7 \mathrm{H}-4-105$ & 52.74 & 0.04 & 0.11 & 17.89 & 0.15 & 0.49 \\
\hline $7 \mathrm{H}-5-41$ & 53.56 & 0.01 & 0.00 & 2.07 & 0.02 & 0.20 \\
\hline $7 \mathrm{H}-5-120$ & 54.32 & 0.00 & 0.04 & 5.42 & 0.00 & 0.84 \\
\hline $7 \mathrm{H}-6-32$ & 54.92 & 0.00 & 0.00 & 12.44 & 0.00 & 0.33 \\
\hline $7 \mathrm{H}-6-120$ & 55.76 & 0.06 & 0.15 & 13.34 & 0.00 & 0.04 \\
\hline $7 \mathrm{H}-7-12$ & 56.16 & 0.00 & 0.00 & 4.13 & 0.07 & 0.32 \\
\hline $7 \mathrm{H}-7-56$ & 56.59 & 0.00 & 0.00 & 7.85 & 0.13 & 0.93 \\
\hline $8 \mathrm{H}-1-55$ & 57.45 & 0.00 & 0.00 & 8.69 & 0.21 & 1.72 \\
\hline $8 \mathrm{H}-1-88$ & 57.78 & 0.00 & 0.00 & 2.95 & 0.07 & 0.19 \\
\hline $8 \mathrm{H}-2-19$ & 58.56 & 0.00 & 0.00 & 5.74 & 0.08 & 0.50 \\
\hline $8 \mathrm{H}-2-137$ & 59.71 & 0.00 & 0.00 & 5.23 & 0.06 & 0.24 \\
\hline $8 \mathrm{H}-3-15$ & 59.98 & 0.00 & 0.00 & 6.90 & 0.34 & 0.99 \\
\hline $8 \mathrm{H}-3-113$ & 60.94 & 0.00 & 0.04 & 13.33 & 1.05 & 3.66 \\
\hline $8 \mathrm{H}-4-19$ & 61.48 & 0.00 & 0.00 & 0.76 & 0.03 & 0.17 \\
\hline $8 \mathrm{H}-4-112$ & 62.39 & 0.00 & 0.00 & 16.97 & 0.93 & 3.38 \\
\hline $8 \mathrm{H}-5-20$ & 62.95 & 0.00 & 0.04 & 30.17 & 1.56 & 4.30 \\
\hline $8 \mathrm{H}-5-119$ & 63.91 & 0.00 & 0.04 & 13.45 & 0.73 & 2.16 \\
\hline $8 \mathrm{H}-6-20$ & 64.41 & 0.00 & 0.00 & 1.34 & 0.01 & 0.14 \\
\hline $8 \mathrm{H}-6-94$ & 65.13 & 0.00 & 0.00 & 19.87 & 0.34 & 0.78 \\
\hline $8 \mathrm{H}-7-18$ & 65.85 & 0.00 & 0.00 & 6.61 & 0.05 & 0.73 \\
\hline $8 \mathrm{H}-7-44$ & 66.10 & 0.00 & 0.00 & 10.77 & 0.02 & 0.51 \\
\hline $9 \mathrm{H}-1-28$ & 66.69 & 0.00 & 0.00 & 10.09 & 0.23 & 1.45 \\
\hline
\end{tabular}

Table A2. Carbonate/organic carbon/coarse-fraction contents, Hole $642 \mathrm{C} / \mathrm{D}$.

\begin{tabular}{|c|c|c|c|c|}
\hline Sample & $\begin{array}{l}\text { Depth } \\
\text { (mbsf) }\end{array}$ & $\begin{array}{l}\% \text { Coarse } \\
\text { fraction }\end{array}$ & $\%$ TOC & $\begin{array}{c}\% \text { Carb. } \\
\text { bulk }\end{array}$ \\
\hline \multicolumn{5}{|l|}{ Hole $642 \mathrm{C} / \mathrm{D}$} \\
\hline $1 \mathrm{H}-1-5$ & 0.07 & 12.70 & 0.72 & 28.24 \\
\hline $1 \mathrm{H}-1-67$ & 0.69 & 15.33 & 0.59 & 4.57 \\
\hline $1 \mathrm{H}-2-6$ & 1.58 & 6.42 & 0.24 & 8.79 \\
\hline $1 \mathrm{H}-2-138$ & 2.90 & 22.39 & 0.73 & 0.55 \\
\hline $1 \mathrm{H}-3-0$ & 3.01 & 13.88 & 0.24 & 13.10 \\
\hline $1 \mathrm{H}-\mathrm{C}-3$ & 3.03 & 25.60 & 0.21 & 3.31 \\
\hline $2 \mathrm{H}-1-84$ & 4.23 & 27.36 & 0.55 & 0.00 \\
\hline $2 \mathrm{H}-1-138$ & 4.77 & 16.29 & 0.25 & 9.43 \\
\hline $2 \mathrm{H}-2-16$ & 5.05 & 9.72 & 0.22 & 7.70 \\
\hline $2 \mathrm{H}-2-132$ & 6.19 & 17.92 & 0.87 & 0.43 \\
\hline $2 \mathrm{H}-3-39$ & 6.75 & 6.76 & 0.24 & 28.13 \\
\hline $2 \mathrm{H}-3-142$ & 7.76 & 17.63 & 0.27 & 4.48 \\
\hline $2 \mathrm{H}-4-36$ & 8.19 & 18.13 & 0.71 & 0.35 \\
\hline $2 \mathrm{H}-4-132$ & 9.13 & 7.99 & 0.20 & 7.51 \\
\hline $2 \mathrm{H}-5-10$ & 9.41 & 7.36 & 0.23 & 9.28 \\
\hline $2 \mathrm{H}-5-101$ & 10.30 & 13.71 & 0.80 & 0.00 \\
\hline $2 \mathrm{H}-6-45$ & 11.22 & 5.40 & 0.38 & 6.86 \\
\hline $2 \mathrm{H}-6-104$ & 11.80 & 17.76 & 0.70 & 0.00 \\
\hline $2 \mathrm{H}-7-3$ & 12.28 & 5.97 & 0.29 & 7.34 \\
\hline $3 H-1-63$ & 13.85 & 22.44 & 0.28 & 0.00 \\
\hline $3 \mathrm{H}-1-110$ & 14.32 & 16.15 & 0.77 & 1.06 \\
\hline $3 \mathrm{H}-2-14$ & 14.86 & 9.76 & 0.36 & 9.00 \\
\hline $3 H-2-66$ & 15.38 & 20.50 & 0.40 & 5.27 \\
\hline $3 \mathrm{H}-3-19$ & 16.41 & 5.07 & 0.26 & 10.32 \\
\hline $3 \mathrm{H}-3-79$ & 17.00 & 36.65 & 0.70 & 0.30 \\
\hline $3 \mathrm{H}-3-129$ & 17.51 & 1.14 & 1.03 & 0.00 \\
\hline $3 \mathrm{H}-4-18$ & 17.90 & 20.33 & 1.10 & 0.00 \\
\hline $3 \mathrm{H}-4-130$ & 19.02 & 9.70 & 0.26 & 22.11 \\
\hline $3 \mathrm{H}-5-15$ & 19.37 & 6.30 & 0.34 & 20.10 \\
\hline 3 H-5- 129 & 20.51 & 16.47 & 0.34 & 29.69 \\
\hline $3 \mathrm{H}-6-44$ & 21.06 & 24.89 & 0.71 & 2.89 \\
\hline $3 \mathrm{H}-6-142$ & 22.04 & 3.28 & 0.27 & 19.00 \\
\hline $3 \mathrm{H}-7-11$ & 22.33 & 4.91 & 0.43 & 7.66 \\
\hline $3 \mathrm{H}-7-50$ & 22.72 & 4.83 & 0.39 & 6.36 \\
\hline $4 \mathrm{H}-1-44$ & 23.56 & 3.69 & 0.47 & 1.75 \\
\hline $4 H-1-139$ & 24.50 & 16.57 & 0.73 & 1.14 \\
\hline $4 \mathrm{H}-2-17$ & 24.77 & 10.28 & 0.94 & 8.97 \\
\hline
\end{tabular}


Table A2 (continued).

\begin{tabular}{|c|c|c|c|c|c|c|}
\hline Sample & $\begin{array}{l}\text { Depth } \\
\text { (mbsf) }\end{array}$ & $\begin{array}{l}\% \text { Coarse } \\
\text { fraction }\end{array}$ & $\%$ TOC & $\begin{array}{l}\% \text { Carb. } \\
\text { bulk }\end{array}$ & & \\
\hline \multicolumn{7}{|c|}{ Hole $642 \mathrm{C} / \mathrm{D}$ (Cont.) } \\
\hline $4 \mathrm{H}-2-107$ & 25.66 & 14.56 & 0.99 & 0.20 & & \\
\hline $4 \mathrm{H}-3-29$ & 26.38 & 25.91 & 0.48 & 3.93 & & \\
\hline $4 \mathrm{H}-3-134$ & 27.42 & 7.22 & 0.29 & 8.10 & & \\
\hline $4 \mathrm{H}-4-32$ & 27.89 & 8.09 & 0.31 & 8.38 & & \\
\hline $4 \mathrm{H}-4-120$ & 28.76 & 6.80 & 0.53 & 0.22 & & \\
\hline $4 \mathrm{H}-5-41$ & 29.47 & 23.07 & 0.59 & 0.29 & & \\
\hline $4 \mathrm{H}-5-135$ & 30.40 & 9.89 & 0.22 & 4.53 & & \\
\hline $4 \mathrm{H}-6-13$ & 30.67 & 9.88 & 0.49 & 0.46 & & \\
\hline $4 \mathrm{H}-6-137$ & 31.90 & 14.15 & 0.26 & 0.67 & & \\
\hline $4 \mathrm{H}-7-13$ & 32.16 & 3.08 & 0.34 & 2.04 & & \\
\hline 4H-7-48 & 32.51 & 14.64 & 0.46 & 0.00 & & \\
\hline $5 \mathrm{H}-1-57$ & 33.48 & 11.51 & 0.22 & 3.79 & & \\
\hline $5 H-1-139$ & 34.29 & 6.21 & 0.30 & 4.35 & & \\
\hline $5 \mathrm{H}-2-40$ & 34.79 & 37.97 & 0.11 & 5.27 & & \\
\hline $5 \mathrm{H}-2-133$ & 35.71 & 22.13 & 0.22 & 6.33 & & \\
\hline $5 \mathrm{H}-3-17$ & 36.04 & 8.72 & 0.21 & 6.43 & & \\
\hline $5 \mathrm{H}-3-139$ & 37.24 & 12.38 & 1.01 & 3.57 & & \\
\hline $5 \mathrm{H}-4-56$ & 37.90 & 20.45 & 0.57 & 0.00 & & \\
\hline $5 \mathrm{H}-4-117$ & 38.51 & 8.18 & 0.26 & 0.31 & & \\
\hline $5 \mathrm{H}-5-17$ & 39.00 & 18.21 & 0.40 & 0.00 & & \\
\hline $5 \mathrm{H}-5-128$ & 40.09 & 14.56 & 0.22 & 0.00 & & \\
\hline $5 \mathrm{H}-6-2$ & 40.33 & 17.67 & 0.81 & 0.07 & & \\
\hline $5 \mathrm{H}-6-82$ & 41.12 & 10.57 & 0.20 & 0.00 & & \\
\hline $6 \mathrm{H}-1-48$ & 41.90 & 10.70 & 0.27 & 0.00 & & \\
\hline $6 \mathrm{H}-1-104$ & 42.46 & 11.93 & 0.99 & 0.01 & & \\
\hline $6 \mathrm{H}-2-80$ & 43.72 & 29.94 & 0.82 & 0.00 & & \\
\hline $6 \mathrm{H}-2-138$ & 44.30 & 7.79 & 0.23 & 0.30 & & \\
\hline $6 \mathrm{H}-3-36$ & 44.78 & 17.59 & 0.62 & 0.00 & & \\
\hline $6 \mathrm{H}-3-127$ & 45.69 & 3.48 & 0.33 & 0.00 & & \\
\hline $6 \mathrm{H}-4-3$ & 45.95 & 25.97 & 0.21 & 0.00 & & \\
\hline $6 \mathrm{H}-4-70$ & 46.62 & 16.60 & 0.70 & 0.05 & & \\
\hline $6 \mathrm{H}-5-13$ & 47.55 & 7.93 & 0.44 & 0.00 & & \\
\hline $6 \mathrm{H}-5-84$ & 48.26 & 12.67 & 1.05 & 0.01 & & \\
\hline $6 \mathrm{H}-6-14$ & 49.06 & 5.53 & 0.45 & 0.00 & & \\
\hline $6 \mathrm{H}-6-95$ & 49.87 & 15.12 & 1.08 & 0.00 & & \\
\hline $6 \mathrm{H}-\mathrm{C}-4$ & 50.46 & 14.04 & 0.28 & 0.00 & & \\
\hline $7 \mathrm{H}-1-103$ & 51.93 & 14.08 & 0.82 & 0.00 & & \\
\hline $7 \mathrm{H}-2-103$ & 53.39 & 12.52 & 0.37 & 0.00 & & \\
\hline $7 \mathrm{H}-3-103$ & 54.86 & 2.67 & 0.43 & 0.00 & & \\
\hline $7 \mathrm{H}-4-103$ & 56.33 & 0.18 & 0.63 & 0.00 & & \\
\hline $8 \mathrm{H}-1-113$ & 58.15 & 7.39 & 0.33 & 0.00 & & \\
\hline $8 \mathrm{H}-2-113$ & 59.52 & 1.93 & 0.35 & 0.09 & & \\
\hline $9 \mathrm{H}-1-116$ & 61.88 & 0.31 & 0.42 & 50.14 & & \\
\hline $9 \mathrm{H}-2-107$ & 62.29 & 1.08 & 0.39 & 49.25 & & \\
\hline Section & $\begin{array}{l}\text { Depth } \\
\text { (mbsf) }\end{array}$ & $\begin{array}{l}\% \text { Benthic } \\
\text { foram. }\end{array}$ & $\begin{array}{l}\text { \% Plankt } \\
\text { foram }\end{array}$ & $\begin{array}{c}\% \\
\text { Quartz }\end{array}$ & $\begin{array}{c}\% \\
\text { Feldspar }\end{array}$ & $\begin{array}{c}\% \text { Rock } \\
\text { fragments }\end{array}$ \\
\hline
\end{tabular}

Hole 642C: Coarse-fraction composition (subfraction $125 \mu \mathrm{m}-500 \mu \mathrm{m}$ )

$\begin{array}{lrrrrrr}\text { 1H-1-5 } & 0.07 & 0.51 & 2.30 & 7.59 & 0.00 & 0.00 \\ 1 \mathrm{H}-1-67 & 0.69 & 0.12 & 0.61 & 13.14 & 0.29 & 0.03 \\ 1 \mathrm{H}-2-6 & 1.58 & 0.07 & 0.46 & 5.42 & 0.09 & 0.01 \\ 1 \mathrm{H}-2-138 & 2.90 & 0.00 & 0.00 & 20.80 & 0.22 & 0.04 \\ 1 \mathrm{H}-3-0 & 3.01 & 0.32 & 10.04 & 3.46 & 0.00 & 0.00 \\ 1 \mathrm{H}-\mathrm{C}-3 & 3.03 & 0.00 & 0.15 & 24.19 & 0.28 & 0.00 \\ 2 \mathrm{H}-1-84 & 4.23 & 0.00 & 0.25 & 25.53 & 0.38 & 0.00 \\ 2 \mathrm{H}-1-138 & 4.77 & 0.00 & 0.00 & 0.00 & 0.00 & 0.00 \\ 2 \mathrm{H}-2-16 & 5.05 & 0.00 & 0.00 & 0.00 & 0.00 & 0.00 \\ 2 \mathrm{H}-2-132 & 6.19 & 0.07 & 1.31 & 15.48 & 0.16 & 0.04 \\ 2 \mathrm{H}-3-39 & 6.75 & 0.19 & 6.02 & 0.45 & 0.00 & 0.00 \\ 2 \mathrm{H}-3-142 & 7.76 & 0.00 & 0.07 & 15.88 & 0.30 & 0.14 \\ 2 \mathrm{H}-4-36 & 8.19 & 0.09 & 0.76 & 15.72 & 0.22 & 0.15 \\ 2 \mathrm{H}-4-132 & 9.13 & 0.08 & 0.39 & 6.99 & 0.14 & 0.02 \\ 2 \mathrm{H}-5-10 & 9.41 & 0.10 & 3.76 & 2.94 & 0.08 & 0.05 \\ 2 \mathrm{H}-5-101 & 10.30 & 0.00 & 0.19 & 11.19 & 0.26 & 0.23 \\ 2 \mathrm{H}-6-45 & 11.22 & 0.05 & 0.44 & 4.30 & 0.09 & 0.03 \\ 2 \mathrm{H}-6-104 & 11.80 & 0.00 & 0.16 & 14.19 & 0.16 & 0.20 \\ 2 \mathrm{H}-7-3 & 12.28 & 0.13 & 1.62 & 3.90 & 0.06 & 0.00 \\ 3 \mathrm{H}-1-63 & 13.85 & 0.04 & 0.16 & 19.77 & 0.61 & 0.11 \\ 3 \mathrm{H}-1-110 & 14.32 & 0.00 & 0.03 & 14.23 & 0.29 & 0.11 \\ 3 \mathrm{H}-2-14 & 14.86 & 0.02 & 1.29 & 7.51 & 0.25 & 0.02 \\ 3 \mathrm{H}-2-66 & 15.38 & 0.00 & 0.08 & 18.65 & 0.41 & 0.04 \\ 3 \mathrm{H}-3-19 & 16.41 & 0.05 & 0.09 & 4.37 & 0.12 & 0.03 \\ 3 \mathrm{H}-3-79 & 17.00 & 0.00 & 0.29 & 34.63 & 0.22 & 0.15 \\ & & & & & & \end{array}$


Table A2 (continued).

\begin{tabular}{|c|c|c|c|c|c|c|}
\hline Section & $\begin{array}{l}\text { Depth } \\
\text { (mbsf) }\end{array}$ & $\begin{array}{l}\% \text { Benthic } \\
\text { foram. }\end{array}$ & $\begin{array}{l}\% \text { Planktonic } \\
\text { foram. }\end{array}$ & $\begin{array}{c}\% \\
\text { Quartz }\end{array}$ & $\begin{array}{c}\% \\
\text { Feldspar }\end{array}$ & $\begin{array}{c}\% \text { Rock } \\
\text { fragments }\end{array}$ \\
\hline \multicolumn{7}{|c|}{ Hole 642C: Coarse-fraction composition (subfraction $125 \mu \mathrm{m}-500 \mu \mathrm{m}$ ) (Cont.) } \\
\hline $3 \mathrm{H}-3-129$ & 17.51 & 0.08 & 0.99 & 0.04 & 0.00 & 0.00 \\
\hline $3 \mathrm{H}-4-18$ & 17.90 & 0.00 & 0.16 & 18.93 & 0.30 & 0.00 \\
\hline $3 \mathrm{H}-4-130$ & 19.02 & 0.34 & 7.01 & 1.99 & 0.00 & 0.03 \\
\hline $3 \mathrm{H}-5-15$ & 19.37 & 0.13 & 5.41 & 0.60 & 0.00 & 0.01 \\
\hline $3 \mathrm{H}-5-129$ & 20.51 & 0.28 & 4.78 & 10.29 & 0.25 & 0.03 \\
\hline $3 \mathrm{H}-6-44$ & 21.06 & 1.29 & 8.46 & 13.61 & 0.15 & 0.07 \\
\hline $3 \mathrm{H}-6-142$ & 22.04 & 0.27 & 2.84 & 0.10 & 0.00 & 0.00 \\
\hline $3 \mathrm{H}-7-11$ & 22.33 & 0.27 & 1.73 & 2.77 & 0.02 & 0.04 \\
\hline $3 \mathrm{H}-7-50$ & 22.72 & 0.04 & 0.58 & 3.97 & 0.00 & 0.10 \\
\hline $4 \mathrm{H}-1-44$ & 23.56 & 0.01 & 0.01 & 3.00 & 0.01 & 0.08 \\
\hline $4 \mathrm{H}-1-139$ & 24.50 & 0.00 & 0.00 & 14.91 & 0.18 & 1.08 \\
\hline $4 \mathrm{H}-2-17$ & 24.77 & 0.38 & 2.01 & 6.23 & 0.09 & 0.50 \\
\hline $4 \mathrm{H}-2-107$ & 25.66 & 0.00 & 0.00 & 11.44 & 0.15 & 2.40 \\
\hline $4 \mathrm{H}-3-29$ & 26.38 & 0.10 & 0.05 & 20.55 & 0.23 & 2.95 \\
\hline $4 \mathrm{H}-3-134$ & 27.42 & 0.19 & 1.13 & 5.28 & 0.04 & 0.27 \\
\hline $4 \mathrm{H}-4-32$ & 27.89 & 0.24 & 1.56 & 5.30 & 0.02 & 0.37 \\
\hline $4 \mathrm{H}-4-120$ & 28.76 & 0.00 & 0.00 & 5.69 & 0.01 & 0.72 \\
\hline $4 \mathrm{H}-5-41$ & 29.47 & 0.00 & 0.00 & 20.32 & 0.12 & 2.05 \\
\hline $4 \mathrm{H}-5-135$ & 30.40 & 0.04 & 1.16 & 7.56 & 0.02 & 0.41 \\
\hline $4 \mathrm{H}-6-13$ & 30.67 & 0.02 & 0.00 & 7.63 & 0.96 & 0.95 \\
\hline $4 \mathrm{H}-6-137$ & 31.90 & 0.00 & 0.00 & 11.29 & 1.47 & 0.95 \\
\hline $4 \mathrm{H}-7-13$ & 32.16 & 0.04 & 0.01 & 2.31 & 0.28 & 0.35 \\
\hline $4 \mathrm{H}-7-48$ & 32.51 & 0.00 & 0.00 & 9.62 & 2.72 & 2.08 \\
\hline $5 \mathrm{H}-1-57$ & 33.48 & 0.07 & 0.47 & 7.85 & 1.46 & 1.22 \\
\hline $5 \mathrm{H}-1-139$ & 34.29 & 0.00 & 0.09 & 4.85 & 0.69 & 0.43 \\
\hline $5 \mathrm{H}-2-40$ & 34.79 & 0.34 & 10.90 & 22.52 & 3.19 & 0.42 \\
\hline $5 \mathrm{H}-2-133$ & 35.71 & 0.18 & 1.04 & 16.91 & 2.52 & 0.35 \\
\hline $5 \mathrm{H}-3-17$ & 36.04 & 0.01 & 0.08 & 6.18 & 0.69 & 0.22 \\
\hline $5 \mathrm{H}-3-139$ & 37.24 & 0.00 & 0.00 & 8.88 & 1.81 & 1.54 \\
\hline $5 \mathrm{H}-4-56$ & 37.90 & 0.00 & 0.00 & 13.07 & 4.44 & 2.54 \\
\hline $5 \mathrm{H}-4-117$ & 38.51 & 0.00 & 0.00 & 5.81 & 1.60 & 0.60 \\
\hline $5 \mathrm{H}-5-17$ & 39.00 & 0.00 & 0.00 & 13.80 & 1.98 & 1.98 \\
\hline $5 \mathrm{H}-5-128$ & 40.09 & 0.03 & 0.00 & 11.01 & 1.72 & 1.66 \\
\hline $5 \mathrm{H}-6-2$ & 40.33 & 0.00 & 0.00 & 12.99 & 1.64 & 2.83 \\
\hline $5 \mathrm{H}-6-82$ & 41.12 & 0.00 & 0.00 & 9.45 & 0.44 & 0.40 \\
\hline $6 \mathrm{H}-1-48$ & 41.90 & 0.00 & 0.00 & 8.92 & 0.41 & 0.79 \\
\hline $6 \mathrm{H}-1-104$ & 42.46 & 0.00 & 0.00 & 9.17 & 0.45 & 1.79 \\
\hline $6 \mathrm{H}-2-80$ & 43.72 & 0.00 & 0.00 & 24.37 & 2.93 & 2.43 \\
\hline $6 \mathrm{H}-2-138$ & 44.30 & 0.00 & 0.04 & 5.94 & 0.44 & 0.41 \\
\hline $6 \mathrm{H}-3-36$ & 44.78 & 0.00 & 0.00 & 13.53 & 1.32 & 2.52 \\
\hline $6 \mathrm{H}-3-127$ & 45.69 & 0.00 & 0.00 & 2.80 & 0.23 & 0.42 \\
\hline $6 \mathrm{H}-4-3$ & 45.95 & 0.00 & 0.00 & 22.52 & 1.22 & 1.61 \\
\hline $6 \mathrm{H}-4-70$ & 46.62 & 0.00 & 0.00 & 13.18 & 1.18 & 2.04 \\
\hline $6 \mathrm{H}-5-13$ & 47.55 & 0.00 & 0.00 & 7.06 & 0.21 & 0.31 \\
\hline $6 \mathrm{H}-5-84$ & 48.26 & 0.00 & 0.00 & 10.17 & 0.89 & 1.18 \\
\hline $6 \mathrm{H}-6-14$ & 49.06 & 0.00 & 0.00 & 4.37 & 0.18 & 0.50 \\
\hline $6 \mathrm{H}-6-95$ & 49.87 & 0.00 & 0.00 & 12.02 & 0.97 & 1.62 \\
\hline $6 \mathrm{H}-\mathrm{C}-4$ & 50.46 & 0.00 & 0.00 & 11.61 & 0.03 & 0.38 \\
\hline $7 \mathrm{H}-1-103$ & 51.93 & 0.00 & 0.00 & 12.69 & 0.10 & 0.39 \\
\hline $7 \mathrm{H}-2-103$ & 53.39 & 0.00 & 0.00 & 10.87 & 0.00 & 0.96 \\
\hline $7 \mathrm{H}-3-103$ & 54.86 & 0.00 & 0.00 & 0.00 & 0.00 & 0.00 \\
\hline
\end{tabular}

Table A3. Carbonate/organic carbon/coarse-fraction contents, Hole 643A.

\begin{tabular}{lrrrrr}
\hline Sample & $\begin{array}{c}\text { Depth } \\
\text { (mbsf) }\end{array}$ & $\begin{array}{c}\text { \% Carb. } \\
\text { bulk }\end{array}$ & $\%$ TOC & $\begin{array}{r}\% \text { Carb. } \\
>63 \mu \mathrm{m}\end{array}$ & $\begin{array}{r}\% \text { Carb. } \\
<63 \mu \mathrm{m}\end{array}$ \\
\hline Hole 643A & & & & & \\
& & & & & \\
$1 \mathrm{H}-1-20$ & 0.20 & 10.28 & 0.28 & 7.89 & 2.39 \\
$1 \mathrm{H}-1-60$ & 0.60 & 8.45 & 0.19 & 7.69 & 0.76 \\
$1 \mathrm{H}-1-101$ & 1.01 & 6.79 & 0.20 & 6.18 & 0.61 \\
1H-1-141 & 1.41 & 11.01 & 0.42 & 3.38 & 7.63 \\
$1 \mathrm{H}-2-41$ & 1.90 & 0.00 & 1.11 & 0.00 & 0.00 \\
$1 \mathrm{H}-2-81$ & 2.31 & 37.93 & 0.19 & 6.76 & 31.17 \\
$1 \mathrm{H}-2-121$ & 2.71 & 28.51 & 0.27 & 10.95 & 17.56 \\
$1 \mathrm{H}-3-40$ & 3.40 & 10.37 & 0.19 & 0.00 & 10.37 \\
$1 \mathrm{H}-3-82$ & 3.62 & 0.00 & 1.06 & 0.00 & 0.00 \\
$1 \mathrm{H}-3-121$ & 4.01 & 0.55 & 0.76 & & \\
$1 \mathrm{H}-3-141$ & 4.41 & 10.15 & 0.29 & 0.00 & 10.15 \\
$1 \mathrm{H}-4-21$ & 4.71 & 0.15 & 0.57 & & \\
$1 \mathrm{H}-4-41$ & 4.91 & 9.25 & 0.56 & 5.91 & 3.34 \\
$2 \mathrm{H}-1-21$ & 5.31 & 4.97 & 0.53 & 0.00 & 4.97
\end{tabular}


Table A3 (continued).

\begin{tabular}{|c|c|c|c|c|c|}
\hline Sample & $\begin{array}{l}\text { Depth } \\
\text { (mbsf) }\end{array}$ & $\begin{array}{l}\% \text { Carb. } \\
\text { bulk }\end{array}$ & $\%$ TOC & $\begin{array}{l}\% \text { Carb. } \\
>63 \mu \mathrm{m}\end{array}$ & $\begin{array}{l}\% \text { Carb. } \\
<63 \mu \mathrm{m}\end{array}$ \\
\hline \multicolumn{6}{|c|}{ Hole 643A (Cont.) } \\
\hline $2 \mathrm{H}-1-40$ & 5.70 & 15.97 & 0.25 & 0.32 & 15.65 \\
\hline $2 \mathrm{H}-1-82$ & 6.12 & 0.00 & 0.95 & & \\
\hline $2 \mathrm{H}-1-142$ & 6.72 & 22.10 & 0.23 & 3.51 & 18.59 \\
\hline $2 \mathrm{H}-2-40$ & 7.20 & 7.29 & 0.20 & 4.80 & 2.49 \\
\hline $2 \mathrm{H}-2-82$ & 7.62 & 13.83 & 0.18 & 3.46 & 10.37 \\
\hline $2 \mathrm{H}-2-120$ & 8.00 & 5.28 & 0.20 & 0.00 & 5.28 \\
\hline $2 \mathrm{H}-2-142$ & 8.22 & 0.00 & 0.25 & 0.00 & 0.00 \\
\hline $2 \mathrm{H}-3-40$ & 8.70 & 9.46 & 0.20 & 6.00 & 3.46 \\
\hline $2 \mathrm{H}-3-82$ & 9.12 & 5.41 & 0.25 & 4.29 & 1.12 \\
\hline $2 \mathrm{H}-3-120$ & 9.50 & 15.90 & 0.21 & 5.27 & 10.63 \\
\hline $2 \mathrm{H}-4-21$ & 10.01 & 10.90 & 0.18 & 5.30 & 5.60 \\
\hline $2 \mathrm{H}-4-60$ & 10.40 & 1.74 & 0.24 & 1.73 & 0.01 \\
\hline $2 \mathrm{H}-4-106$ & 10.86 & 2.06 & 0.39 & & \\
\hline $2 \mathrm{H}-4-120$ & 11.00 & 3.25 & 0.30 & 0.00 & 3.25 \\
\hline $2 \mathrm{H}-5-21$ & 11.51 & 0.04 & 0.37 & 0.00 & 0.04 \\
\hline $2 \mathrm{H}-5-60$ & 11.90 & 4.68 & 0.32 & 3.72 & 0.96 \\
\hline $2 \mathrm{H}-5-120$ & 12.50 & 3.93 & 0.35 & 2.83 & 1.10 \\
\hline $2 \mathrm{H}-6-21$ & 13.01 & 44.34 & 0.19 & 36.09 & 8.25 \\
\hline $2 \mathrm{H}-6-82$ & 13.62 & 8.10 & 0.20 & 7.53 & 0.57 \\
\hline $2 \mathrm{H}-6-111$ & 13.91 & 9.26 & 0.32 & 4.80 & 4.46 \\
\hline $2 \mathrm{H}-6-142$ & 14.22 & 2.12 & 0.32 & 1.93 & 0.19 \\
\hline $2 \mathrm{H}-7-21$ & 14.51 & 0.00 & 0.31 & 0.00 & 0.00 \\
\hline $2 \mathrm{H}-7-40$ & 14.70 & 5.81 & 0.25 & 4.72 & 1.09 \\
\hline $3 \mathrm{H}-1-25$ & 15.05 & 20.28 & 0.23 & 11.08 & 9.20 \\
\hline $3 \mathrm{H}-1-42$ & 15.21 & 10.04 & 0.42 & 4.76 & 5.28 \\
\hline $3 \mathrm{H}-2-20$ & 16.50 & 10.48 & 0.29 & & \\
\hline $3 \mathrm{H}-2-82$ & 17.12 & 10.92 & 0.27 & 5.07 & 5.85 \\
\hline $3 \mathrm{H}-2-142$ & 17.72 & 0.00 & 0.59 & 0.00 & 0.00 \\
\hline $3 \mathrm{H}-3-20$ & 18.00 & 5.40 & 0.63 & & \\
\hline $3 \mathrm{H}-3-25$ & 18.05 & 8.57 & 0.23 & 5.05 & 3.52 \\
\hline $3 \mathrm{H}-3-40$ & 18.20 & 7.06 & 0.96 & & \\
\hline $3 \mathrm{H}-3-82$ & 18.62 & 11.22 & 0.94 & & \\
\hline $3 \mathrm{H}-3-116$ & 18.96 & 8.28 & 0.49 & 0.00 & 8.28 \\
\hline $3 \mathrm{H}-4-20$ & 19.50 & 6.16 & 0.37 & 3.24 & 2.92 \\
\hline $3 \mathrm{H}-4-58$ & 19.88 & 12.20 & 0.46 & 12.08 & 0.12 \\
\hline $3 \mathrm{H}-4-122$ & 20.52 & 20.03 & 0.23 & 7.12 & 12.91 \\
\hline $3 \mathrm{H}-5-20$ & 21.00 & 5.96 & 0.18 & 5.27 & 0.69 \\
\hline $3 \mathrm{H}-5-58$ & 21.38 & 5.46 & 0.23 & 5.06 & 0.40 \\
\hline $3 \mathrm{H}-5-100$ & 21.80 & 2.12 & 0.23 & 0.00 & 2.12 \\
\hline $3 \mathrm{H}-5-140$ & 22.20 & 5.61 & 0.32 & 4.62 & 0.99 \\
\hline $3 \mathrm{H}-6-20$ & 22.50 & 4.11 & 0.26 & 3.58 & 0.53 \\
\hline $3 \mathrm{H}-6-40$ & 22.70 & 7.38 & 0.23 & 6.09 & 1.29 \\
\hline $3 \mathrm{H}-6-100$ & 23.30 & 5.51 & 0.33 & & \\
\hline $3 \mathrm{H}-7-40$ & 24.20 & 6.15 & 0.34 & 4.63 & 1.52 \\
\hline $4 \mathrm{H}-1-20$ & 24.50 & 11.14 & 0.22 & 11.02 & 0.12 \\
\hline $4 \mathrm{H}-1-80$ & 25.10 & 9.84 & 0.23 & 9.53 & 0.31 \\
\hline $4 \mathrm{H}-1-120$ & 25.50 & 5.99 & 0.28 & 3.20 & 2.79 \\
\hline $4 \mathrm{H}-2-20$ & 26.00 & 6.87 & 0.27 & 6.37 & 0.50 \\
\hline $4 \mathrm{H}-2-80$ & 26.60 & 6.15 & 0.41 & & \\
\hline $4 \mathrm{H}-2-100$ & 26.80 & 5.56 & 0.27 & 3.83 & 1.73 \\
\hline $4 \mathrm{H}-2-140$ & 27.30 & 5.79 & 0.27 & 5.61 & 0.18 \\
\hline $4 \mathrm{H}-3-20$ & 27.40 & 0.00 & 1.08 & & \\
\hline $4 \mathrm{H}-3-40$ & 27.60 & 21.02 & 0.23 & & \\
\hline $4 \mathrm{H}-3-60$ & 27.80 & 10.63 & 0.23 & 10.40 & 0.23 \\
\hline $4 \mathrm{H}-3-80$ & 28.00 & 0.00 & 0.48 & 0.00 & 0.00 \\
\hline $4 \mathrm{H}-3-100$ & 28.20 & 3.15 & 0.29 & 2.61 & 0.54 \\
\hline $4 \mathrm{H}-3-120$ & 28.40 & 0.00 & 1.01 & 0.00 & 0.00 \\
\hline $4 \mathrm{H}-4-40$ & 29.20 & 0.00 & 0.24 & 0.00 & 0.00 \\
\hline $4 \mathrm{H}-4-80$ & 29.60 & 6.95 & 0.21 & 3.61 & 3.34 \\
\hline $4 \mathrm{H}-4-120$ & 30.00 & 0.00 & 0.23 & 0.00 & 0.00 \\
\hline $4 \mathrm{H}-5-18$ & 30.48 & 0.00 & 0.18 & 0.00 & 0.00 \\
\hline $4 \mathrm{H}-5-94$ & 31.24 & 2.14 & 0.29 & 0.41 & 1.73 \\
\hline $4 \mathrm{H}-5-120$ & 31.50 & 29.33 & 0.17 & 0.00 & 29.33 \\
\hline $4 \mathrm{H}-6-40$ & 32.20 & 0.00 & 0.47 & 0.00 & 0.00 \\
\hline $4 \mathrm{H}-6-80$ & 32.60 & 4.73 & 0.27 & 2.72 & 2.01 \\
\hline $4 \mathrm{H}-6-120$ & 33.00 & 0.00 & 0.27 & 0.00 & 0.00 \\
\hline $4 \mathrm{H}-6-140$ & 33.20 & 11.88 & 0.19 & 3.91 & 7.97 \\
\hline $4 \mathrm{H}-7-40$ & 33.70 & 0.00 & 0.37 & 0.00 & 0.00 \\
\hline $5 \mathrm{H}-1-42$ & 34.22 & 0.08 & 0.37 & 0.00 & 0.08 \\
\hline $5 \mathrm{H}-1-102$ & 34.82 & 0.00 & 0.27 & 0.00 & 0.00 \\
\hline $5 \mathrm{H}-1-142$ & 35.22 & 3.37 & 1.03 & 2.58 & 0.79 \\
\hline $5 \mathrm{H}-2-42$ & 35.72 & 0.00 & 0.34 & 0.00 & 0.00 \\
\hline $5 \mathrm{H}-2-82$ & 36.12 & 0.00 & 0.28 & 0.00 & 0.00 \\
\hline $5 \mathrm{H}-2-102$ & 36.32 & 0.00 & 0.26 & 0.00 & 0.00 \\
\hline $5 \mathrm{H}-2-123$ & 36.43 & 0.06 & 0.25 & 0.00 & 0.06 \\
\hline $5 \mathrm{H}-3-17$ & 36.97 & 0.00 & 0.18 & 0.00 & 0.00 \\
\hline
\end{tabular}


Table A3 (continued).

\begin{tabular}{|c|c|c|c|c|c|c|}
\hline Sample & $\begin{array}{l}\text { Depth } \\
\text { (mbsf) }\end{array}$ & $\begin{array}{l}\% \text { Carb. } \\
\text { bulk }\end{array}$ & $\%$ TOC & $\begin{array}{l}\% \text { Carb. } \\
>63 \mu \mathrm{m}\end{array}$ & $\begin{array}{l}\% \text { Carb. } \\
<63 \mu \mathrm{m}\end{array}$ & \\
\hline \multicolumn{7}{|c|}{ Hole 643A (Cont.) } \\
\hline $5 \mathrm{H}-3-62$ & 37.42 & 0.00 & 0.18 & 0.00 & 0.00 & \\
\hline $5 \mathrm{H}-3-102$ & 37.82 & 0.00 & 0.48 & 0.00 & 0.00 & \\
\hline $5 \mathrm{H}-4-42$ & 38.72 & 0.00 & 0.20 & 0.00 & 0.00 & \\
\hline $5 \mathrm{H}-4-102$ & 39.32 & 0.00 & 0.26 & 0.00 & 0.00 & \\
\hline $5 \mathrm{H}-4-143$ & 39.62 & 0.00 & 1.08 & 0.00 & 0.00 & \\
\hline $5 \mathrm{H}-5-17$ & 39.97 & 0.00 & 0.23 & 0.00 & 0.00 & \\
\hline $5 \mathrm{H}-5-82$ & 40.62 & 0.00 & 0.21 & 0.00 & 0.00 & \\
\hline $5 \mathrm{H}-5-123$ & 41.03 & 0.00 & 0.27 & 0.00 & 0.00 & \\
\hline $5 \mathrm{H}-6-42$ & 41.72 & 0.00 & 0.33 & 0.00 & 0.00 & \\
\hline $5 \mathrm{H}-6-82$ & 42.12 & 0.00 & 0.39 & 0.00 & 0.00 & \\
\hline $5 \mathrm{H}-6-122$ & 42.42 & 0.00 & 0.41 & 0.00 & 0.00 & \\
\hline $5 \mathrm{H}-6-142$ & 42.62 & 0.00 & 0.99 & 0.00 & 0.00 & \\
\hline $6 \mathrm{H}-1-20$ & 43.50 & 0.00 & 0.88 & 0.00 & 0.00 & \\
\hline $6 \mathrm{H}-1-102$ & 44.32 & 0.00 & 0.33 & 0.00 & 0.00 & \\
\hline $6 \mathrm{H}-1-142$ & 44.72 & 0.00 & 0.23 & 0.00 & 0.00 & \\
\hline $6 \mathrm{H}-2-20$ & 45.00 & 0.00 & 0.21 & 0.00 & 0.00 & \\
\hline $6 \mathrm{H}-2-102$ & 45.82 & 0.00 & 0.30 & 0.00 & 0.00 & \\
\hline $6 \mathrm{H}-2-120$ & 46.00 & 0.00 & 0.67 & 0.00 & 0.00 & \\
\hline $6 \mathrm{H}-2-142$ & 46.20 & 0.00 & 0.64 & 0.00 & 0.00 & \\
\hline $6 \mathrm{H}-3-42$ & 46.72 & 0.00 & 0.25 & 0.00 & 0.00 & \\
\hline $6 \mathrm{H}-3-83$ & 47.13 & 0.00 & 0.20 & 0.00 & 0.00 & \\
\hline $6 \mathrm{H}-3-120$ & 47.50 & 0.00 & 0.23 & 0.00 & 0.00 & \\
\hline $6 \mathrm{H}-4-20$ & 48.00 & 0.00 & 0.23 & 0.00 & 0.00 & \\
\hline $6 \mathrm{H}-4-61$ & 48.40 & 0.00 & 0.23 & 0.00 & 0.00 & \\
\hline $6 \mathrm{H}-4-102$ & 48.82 & 0.00 & 0.32 & 0.00 & 0.00 & \\
\hline $6 \mathrm{H}-5-42$ & 49.72 & 0.00 & 0.25 & 0.00 & 0.00 & \\
\hline $6 \mathrm{H}-5-83$ & 50.13 & 0.00 & 0.31 & 0.00 & 0.00 & \\
\hline $6 \mathrm{H}-5-120$ & 50.50 & 0.00 & 0.25 & 0.00 & 0.00 & \\
\hline $6 \mathrm{H}-6-42$ & 51.22 & 0.00 & 0.15 & 0.00 & 0.00 & \\
\hline $6 \mathrm{H}-6-60$ & 51.40 & 0.00 & 0.19 & 0.00 & 0.00 & \\
\hline $7 \mathrm{H}-1-62$ & 53.42 & 0.00 & 0.14 & 0.00 & 0.00 & \\
\hline Section & $\begin{array}{l}\text { Depth } \\
\text { (mbsf) }\end{array}$ & $\begin{array}{c}\% \text { Benthic } \\
\text { foram. }\end{array}$ & $\begin{array}{l}\text { \% Plan } \\
\text { fora }\end{array}$ & $\begin{array}{c}\% \\
\text { Quartz }\end{array}$ & $\begin{array}{c}\% \\
\text { Feldspar }\end{array}$ & $\begin{array}{c}\% \text { Rock } \\
\text { fragments }\end{array}$ \\
\hline
\end{tabular}

Hole 643A: Coarse-fraction composition (subfraction $125 \mu \mathrm{m}-500 \mu \mathrm{m}$ )

$\begin{array}{lrrrrrr}1 \mathrm{H}-1-20 & 0.20 & 0.25 & 3.99 & 5.59 & 0.25 & 0.66 \\ 1 \mathrm{H}-1-40 & 0.40 & 0.48 & 7.26 & 15.55 & 0.96 & 0.74 \\ 1 \mathrm{H}-1-60 & 0.60 & 0.01 & 0.35 & 3.76 & 0.55 & 0.22 \\ 1 \mathrm{H}-1-81 & 0.80 & 0.05 & 5.17 & 2.96 & 0.54 & 0.15 \\ 1 \mathrm{H}-1-101 & 1.01 & 0.05 & 0.14 & 4.91 & 0.06 & 0.39 \\ 1 \mathrm{H}-1-121 & 1.21 & 0.13 & 7.22 & 11.65 & 0.38 & 0.94 \\ 1 \mathrm{H}-1-141 & 1.41 & 0.05 & 11.22 & 10.82 & 0.65 & 0.80 \\ 1 \mathrm{H}-2-20 & 1.70 & 0.00 & 0.05 & 18.04 & 5.39 & 2.49 \\ 1 \mathrm{H}-2-41 & 1.90 & 0.00 & 0.15 & 11.68 & 4.14 & 2.32 \\ 1 \mathrm{H}-2-64 & 2.14 & 0.30 & 33.71 & 2.06 & 0.56 & 0.30 \\ 1 \mathrm{H}-2-81 & 2.31 & 0.83 & 23.89 & 4.59 & 0.12 & 0.55 \\ 1 \mathrm{H}-2-101 & 2.51 & 0.99 & 18.29 & 6.21 & 0.08 & 1.19 \\ 1 \mathrm{H}-3-40 & 2.71 & 0.00 & 0.56 & 8.42 & 0.71 & 3.29 \\ 1 \mathrm{H}-3-62 & 3.40 & 0.01 & 0.30 & 3.16 & 0.33 & 0.48 \\ 1 \mathrm{H}-3-82 & 3.62 & 0.00 & 0.24 & 18.02 & 0.39 & 2.36 \\ 1 \mathrm{H}-3-101 & 3.82 & 0.06 & 6.78 & 6.69 & 0.06 & 0.27 \\ 1 \mathrm{H}-3-141 & 4.41 & 0.04 & 11.77 & 5.43 & 0.33 & 0.57 \\ 1 \mathrm{H}-4-21 & 4.71 & 0.00 & 0.23 & 22.97 & 2.04 & 3.43 \\ 1 \mathrm{H}-4-41 & 4.91 & 0.05 & 1.05 & 12.37 & 1.79 & 1.09 \\ 2 \mathrm{H}-1-21 & 5.31 & 0.09 & 3.15 & 9.54 & 0.92 & 3.08 \\ 2 \mathrm{H}-1-40 & 5.70 & 0.10 & 21.42 & 2.41 & 0.17 & 0.62 \\ 2 \mathrm{H}-1-60 & 5.90 & 0.04 & 7.52 & 1.54 & 0.10 & 0.21 \\ 2 \mathrm{H}-1-82 & 6.12 & 0.00 & 0.04 & 10.87 & 2.11 & 4.72 \\ 2 \mathrm{H}-1-100 & 6.30 & 0.13 & 0.00 & 13.40 & 2.09 & 4.97 \\ 2 \mathrm{H}-1-120 & 6.50 & 0.02 & 4.11 & 1.35 & 0.06 & 0.15 \\ 2 \mathrm{H}-1-142 & 6.72 & 0.52 & 20.11 & 0.84 & 0.00 & 0.09 \\ 2 \mathrm{H}-2-21 & 7.01 & 0.29 & 12.62 & 1.01 & 0.00 & 0.11 \\ 2 \mathrm{H}-2-40 & 7.20 & 0.47 & 6.99 & 2.83 & 0.14 & 0.49 \\ 2 \mathrm{H}-2-60 & 7.40 & 0.12 & 6.43 & 5.78 & 0.09 & 0.73 \\ 2 \mathrm{H}-2-82 & 7.62 & 0.07 & 14.74 & 2.48 & 0.21 & 0.21 \\ 2 \mathrm{H}-2-100 & 7.80 & 0.08 & 2.65 & 4.70 & 0.95 & 0.77 \\ 2 \mathrm{H}-2-120 & 8.00 & 0.00 & 0.04 & 7.21 & 0.29 & 1.50 \\ 2 \mathrm{H}-2-142 & 8.22 & 0.00 & 0.01 & 1.99 & 0.69 & 0.37 \\ 2 \mathrm{H}-3-40 & 8.70 & 0.13 & 2.42 & 0.21 & 0.04 & 0.12 \\ 2 \mathrm{H}-3-60 & 8.90 & 0.15 & 8.83 & 2.73 & 0.00 & 0.57 \\ 2 \mathrm{H}-3-82 & 9.12 & 0.05 & 0.92 & 3.71 & 0.79 & 1.32 \\ 2 \mathrm{H}-3-100 & 9.30 & 0.07 & 7.08 & 2.67 & 0.72 & 0.46 \\ 2 \mathrm{H}-3-120 & 9.50 & 0.23 & 19.15 & 1.31 & 0.15 & 0.17 \\ & & & & & & \end{array}$


Table A3 (continued).

\begin{tabular}{|c|c|c|c|c|c|c|}
\hline Section & $\begin{array}{l}\text { Depth } \\
\text { (mbsf) }\end{array}$ & $\begin{array}{l}\% \text { Benthic } \\
\text { foram. }\end{array}$ & $\begin{array}{l}\% \text { Planktonic } \\
\text { foram. }\end{array}$ & $\begin{array}{c}\% \\
\text { Quartz }\end{array}$ & $\begin{array}{c}\% \\
\text { Feldspar }\end{array}$ & $\begin{array}{l}\% \text { Rock } \\
\text { fragment }\end{array}$ \\
\hline \multicolumn{7}{|c|}{ Hole 643A: Coarse-fraction composition (subfraction $125 \mu \mathrm{m}-500 \mu \mathrm{m}$ ) (Cont.) } \\
\hline $2 \mathrm{H}-3-142$ & 9.72 & 0.08 & 13.12 & 2.25 & 0.36 & 0.71 \\
\hline $2 \mathrm{H}-4-21$ & 10.01 & 0.22 & 9.36 & 0.53 & 0.07 & 0.11 \\
\hline $2 \mathrm{H}-4-40$ & 10.20 & 0.28 & 1.08 & 0.03 & 0.00 & 0.08 \\
\hline $2 \mathrm{H}-4-60$ & 10.40 & 0.01 & 0.07 & 0.06 & 0.01 & 0.01 \\
\hline $2 \mathrm{H}-4-82$ & 10.62 & 0.00 & 0.44 & 20.38 & 1.98 & 1.68 \\
\hline $2 \mathrm{H}-4-106$ & 10.86 & 0.00 & 0.00 & 0.01 & 0.00 & 0.00 \\
\hline $2 \mathrm{H}-4-120$ & 11.00 & 0.03 & 0.21 & 5.11 & 0.05 & 1.19 \\
\hline $2 \mathrm{H}-5-21$ & 11.51 & 0.00 & 0.09 & 11.38 & 0.58 & 2.06 \\
\hline $2 \mathrm{H}-5-40$ & 11.70 & 0.00 & 0.41 & 12.34 & 0.33 & 2.14 \\
\hline $2 \mathrm{H}-5-60$ & 11.90 & 0.08 & 3.27 & 14.81 & 0.31 & 1.68 \\
\hline $2 \mathrm{H}-5-82$ & 12.12 & 0.00 & 11.29 & 1.65 & 0.00 & 0.46 \\
\hline $2 \mathrm{H}-5-100$ & 12.30 & 0.11 & 9.64 & 0.63 & 0.00 & 0.14 \\
\hline $2 \mathrm{H}-5-120$ & 12.50 & 0.02 & 0.22 & 9.60 & 0.05 & 1.46 \\
\hline $2 \mathrm{H}-5-142$ & 12.72 & 0.31 & 14.60 & 0.27 & 0.00 & 0.36 \\
\hline $2 \mathrm{H}-6-21$ & 13.01 & 0.26 & 10.34 & 0.17 & 0.00 & 0.10 \\
\hline $2 \mathrm{H}-6-40$ & 13.20 & 0.03 & 1.98 & 11.38 & 0.69 & 1.54 \\
\hline $2 \mathrm{H}-6-60$ & 13.40 & 0.03 & 1.02 & 1.08 & 0.06 & 0.24 \\
\hline $2 \mathrm{H}-6-82$ & 13.62 & 0.02 & 0.95 & 1.20 & 0.04 & 0.23 \\
\hline $2 \mathrm{H}-6-111$ & 13.91 & 0.23 & 6.90 & 1.31 & 0.33 & 0.30 \\
\hline $2 \mathrm{H}-6-120$ & 14.00 & 0.12 & 1.48 & 3.42 & 0.16 & 0.70 \\
\hline $2 \mathrm{H}-6-142$ & 14.22 & 0.00 & 0.28 & 14.14 & 1.50 & 3.78 \\
\hline $2 \mathrm{H}-7-21$ & 14.51 & 0.00 & 0.14 & 19.16 & 1.47 & 2.48 \\
\hline $2 \mathrm{H}-7-40$ & 14.70 & 0.04 & 3.48 & 2.60 & 0.06 & 0.20 \\
\hline $3 \mathrm{H}-1-25$ & 15.05 & 0.33 & 14.49 & 2.12 & 0.45 & 0.54 \\
\hline $3 \mathrm{H}-1-42$ & 15.21 & 0.00 & 5.76 & 2.75 & 0.10 & 0.41 \\
\hline $3 \mathrm{H}-2-20$ & 16.50 & 0.00 & 7.72 & 0.58 & 0.00 & 0.21 \\
\hline $3 \mathrm{H}-2-42$ & 16.72 & 0.18 & 9.08 & 1.41 & 0.08 & 0.30 \\
\hline $3 \mathrm{H}-2-60$ & 16.90 & 0.16 & 18.26 & 0.73 & 0.00 & 0.20 \\
\hline $3 \mathrm{H}-2-82$ & 17.12 & 0.00 & 10.92 & 3.63 & 0.08 & 0.38 \\
\hline $3 \mathrm{H}-2-101$ & 17.31 & 0.00 & 1.18 & 1.21 & 0.02 & 0.17 \\
\hline $3 \mathrm{H}-2-120$ & 17.50 & 0.00 & 0.27 & 6.02 & 0.08 & 0.33 \\
\hline $3 \mathrm{H}-2-142$ & 17.72 & 0.00 & 0.20 & 17.09 & 0.46 & 1.97 \\
\hline $3 \mathrm{H}-3-20$ & 18.00 & 0.00 & 0.33 & 4.45 & 0.38 & 1.37 \\
\hline $3 \mathrm{H}-3-25$ & 18.05 & 0.04 & 2.03 & 13.82 & 0.49 & 1.24 \\
\hline $3 \mathrm{H}-3-40$ & 18.20 & 0.01 & 0.51 & 3.25 & 0.15 & 0.42 \\
\hline $3 \mathrm{H}-3-58$ & 18.38 & 0.04 & 0.34 & 14.90 & 0.34 & 1.71 \\
\hline $3 \mathrm{H}-3-82$ & 18.62 & 0.00 & 0.14 & 0.48 & 0.02 & 0.05 \\
\hline $3 \mathrm{H}-3-116$ & 18.96 & 0.01 & 0.17 & 1.46 & 0.16 & 0.17 \\
\hline $3 \mathrm{H}-3-121$ & 19.03 & 0.00 & 0.00 & 7.56 & 0.46 & 0.78 \\
\hline $3 \mathrm{H}-4-20$ & 19.50 & 0.00 & 0.07 & 11.87 & 1.94 & 2.44 \\
\hline $3 \mathrm{H}-4-42$ & 19.72 & 0.01 & 0.21 & 2.03 & 0.04 & 0.28 \\
\hline $3 \mathrm{H}-4-58$ & 19.88 & 0.00 & 0.18 & 1.53 & 0.16 & 0.38 \\
\hline $3 \mathrm{H}-4-82$ & 20.12 & 0.05 & 0.69 & 1.92 & 0.16 & 0.21 \\
\hline $3 \mathrm{H}-4-100$ & 20.30 & 0.02 & 1.49 & 7.94 & 0.94 & 1.12 \\
\hline $3 \mathrm{H}-4-122$ & 20.52 & 0.00 & 14.40 & 0.30 & 0.00 & 0.09 \\
\hline $3 \mathrm{H}-4-142$ & 20.72 & 0.01 & 2.20 & 3.64 & 0.12 & 0.20 \\
\hline $3 \mathrm{H}-5-20$ & 21.00 & 0.01 & 0.15 & 1.95 & 0.12 & 0.16 \\
\hline $3 \mathrm{H}-5-40$ & 21.20 & 0.24 & 1.95 & 6.93 & 0.16 & 0.68 \\
\hline $3 \mathrm{H}-5-58$ & 21.38 & 0.12 & 4.53 & 1.45 & 0.06 & 0.17 \\
\hline $3 \mathrm{H}-5-82$ & 21.62 & 0.01 & 0.50 & 4.62 & 0.21 & 0.77 \\
\hline $3 \mathrm{H}-5-100$ & 21.80 & 0.02 & 0.83 & 2.73 & 0.03 & 0.30 \\
\hline $3 \mathrm{H}-5-120$ & 22.00 & 0.10 & 1.19 & 8.79 & 0.30 & 1.50 \\
\hline $3 \mathrm{H}-5-140$ & 22.20 & 0.00 & 4.27 & 1.92 & 0.04 & 0.29 \\
\hline $3 \mathrm{H}-6-20$ & 22.50 & 0.00 & 2.99 & 2.29 & 0.12 & 0.17 \\
\hline $3 \mathrm{H}-6-40$ & 22.70 & 0.32 & 5.91 & 1.14 & 0.20 & 0.12 \\
\hline $3 \mathrm{H}-6-58$ & 22.88 & 0.47 & 8.00 & 3.69 & 0.13 & 0.19 \\
\hline $3 \mathrm{H}-6-82$ & 23.12 & 0.00 & 0.23 & 4.46 & 0.34 & 1.71 \\
\hline $3 \mathrm{H}-6-100$ & 23.30 & 0.02 & 0.60 & 1.79 & 0.19 & 0.30 \\
\hline $3 \mathrm{H}-6-120$ & 23.50 & 0.04 & 1.72 & 1.74 & 0.21 & 0.10 \\
\hline $3 \mathrm{H}-6-140$ & 23.70 & 0.02 & 2.38 & 1.27 & 0.22 & 0.22 \\
\hline $3 \mathrm{H}-7-20$ & 24.00 & 0.08 & 6.22 & 2.14 & 0.42 & 0.10 \\
\hline $3 \mathrm{H}-7-40$ & 24.20 & 0.03 & 7.19 & 5.75 & 0.73 & 0.34 \\
\hline $3 \mathrm{H}-7-56$ & 24.30 & 0.05 & 5.57 & 6.83 & 0.28 & 0.30 \\
\hline $4 \mathrm{H}-1-20$ & 24.50 & 0.00 & 0.34 & 1.46 & 0.11 & 0.05 \\
\hline $4 \mathrm{H}-1-40$ & 24.70 & 0.01 & 2.08 & 2.21 & 0.16 & 0.31 \\
\hline $4 \mathrm{H}-1-60$ & 24.90 & 0.00 & 0.03 & 0.66 & 0.03 & 0.04 \\
\hline $4 \mathrm{H}-1-80$ & 25.10 & 0.02 & 0.87 & 2.85 & 0.09 & 0.12 \\
\hline $4 \mathrm{H}-1-94$ & 25.24 & 0.00 & 0.74 & 6.41 & 0.36 & 0.19 \\
\hline $4 \mathrm{H}-1-100$ & 25.30 & 0.00 & 0.77 & 5.37 & 0.33 & 0.09 \\
\hline $4 \mathrm{H}-1-120$ & 25.50 & 0.00 & 4.34 & 1.67 & 0.21 & 0.16 \\
\hline $4 \mathrm{H}-1-140$ & 25.70 & 0.00 & 0.28 & 7.85 & 0.10 & 0.34 \\
\hline $4 \mathrm{H}-2-20$ & 26.00 & 0.05 & 0.11 & 4.22 & 0.35 & 0.17 \\
\hline $4 \mathrm{H}-2-40$ & 26.20 & 0.02 & 0.09 & 2.45 & 0.04 & 0.56 \\
\hline $4 \mathrm{H}-2-60$ & 26.40 & 0.00 & 0.09 & 1.01 & 0.03 & 0.02 \\
\hline $4 \mathrm{H}-2-80$ & 26.60 & 0.00 & 0.02 & 2.05 & 0.08 & 0.22 \\
\hline $4 \mathrm{H}-2-100$ & 26.80 & 0.07 & 5.89 & 2.25 & 0.09 & 0.36 \\
\hline
\end{tabular}


Table A3 (continue).

\begin{tabular}{|c|c|c|c|c|c|c|}
\hline Section & $\begin{array}{l}\text { Depth } \\
\text { (mbsf) }\end{array}$ & $\begin{array}{l}\% \text { Benthic } \\
\text { foram. }\end{array}$ & $\begin{array}{l}\% \text { Planktonic } \\
\text { foram. }\end{array}$ & $\begin{array}{c}\% \\
\text { Quartz }\end{array}$ & $\begin{array}{c}\% \\
\text { Feldspar }\end{array}$ & $\begin{array}{l}\% \text { Rocl } \\
\text { fragmen }\end{array}$ \\
\hline \multicolumn{7}{|c|}{ Hole 643A: Coarse-fraction composition (subfraction $125 \mu \mathrm{m}-500 \mu \mathrm{m}$ ) (Cont.) } \\
\hline $4 \mathrm{H}-2-120$ & 27.00 & 0.00 & 2.51 & 3.33 & 0.11 & 0.55 \\
\hline $4 \mathrm{H}-2-140$ & 27.30 & 0.00 & 0.05 & 1.39 & 0.04 & 0.09 \\
\hline $4 \mathrm{H}-3-20$ & 27.30 & 0.00 & 0.05 & 8.91 & 0.38 & 1.97 \\
\hline $4 \mathrm{H}-3-40$ & 27.60 & 0.01 & 0.00 & 2.44 & 0.09 & 0.19 \\
\hline $4 \mathrm{H}-3-60$ & 27.80 & 0.00 & 0.76 & 1.52 & 0.54 & 0.13 \\
\hline $4 \mathrm{H}-3-80$ & 28.00 & 0.00 & 0.00 & 10.40 & 3.15 & 1.35 \\
\hline $4 \mathrm{H}-3-94$ & 28.14 & 0.00 & 0.85 & 4.44 & 1.08 & 0.66 \\
\hline $4 \mathrm{H}-3-100$ & 28.20 & 0.00 & 0.12 & 1.36 & 0.05 & 0.12 \\
\hline $4 \mathrm{H}-3-120$ & 28.40 & 0.00 & 0.00 & 13.27 & 3.29 & 2.51 \\
\hline $4 \mathrm{H}-3-140$ & 28.60 & 0.09 & 11.32 & 1.78 & 0.50 & 0.47 \\
\hline $4 \mathrm{H}-4-20$ & 29.00 & 0.00 & 0.07 & 14.95 & 0.34 & 1.09 \\
\hline $4 \mathrm{H}-4-40$ & 29.20 & 0.00 & 0.04 & 16.38 & 0.25 & 1.06 \\
\hline $4 \mathrm{H}-4-60$ & 29.40 & 0.00 & 0.10 & 2.60 & 0.03 & 0.50 \\
\hline $4 \mathrm{H}-4-80$ & 29.60 & 0.00 & 7.28 & 2.52 & 0.02 & 0.21 \\
\hline $4 \mathrm{H}-4-100$ & 29.80 & 0.00 & 0.02 & 7.63 & 0.06 & 0.16 \\
\hline $4 \mathrm{H}-4-120$ & 30.00 & 0.00 & 0.03 & 5.55 & 0.14 & 0.73 \\
\hline $4 \mathrm{H}-5-18$ & 30.48 & 0.02 & 0.04 & 9.94 & 0.00 & 0.59 \\
\hline $4 \mathrm{H}-5-40$ & 30.70 & 0.02 & 0.40 & 7.06 & 0.23 & 1.17 \\
\hline $4 \mathrm{H}-5-94$ & 31.24 & 0.04 & 0.18 & 14.57 & 0.24 & 2.13 \\
\hline $4 \mathrm{H}-5-100$ & 31.30 & 0.00 & 2.30 & 10.86 & 0.15 & 1.79 \\
\hline $4 \mathrm{H}-5-120$ & 31.50 & 0.27 & 9.40 & 0.11 & 0.00 & 0.06 \\
\hline $4 \mathrm{H}-5-140$ & 31.70 & 0.00 & 0.13 & 3.91 & 0.05 & 0.30 \\
\hline $4 \mathrm{H}-6-16$ & 31.96 & 0.00 & 0.12 & 6.96 & 0.28 & 0.67 \\
\hline $4 \mathrm{H}-6-40$ & 32.20 & 0.02 & 0.95 & 7.04 & 0.28 & 0.92 \\
\hline $4 \mathrm{H}-6-60$ & 32.40 & 0.00 & 0.36 & 11.52 & 0.47 & 2.33 \\
\hline $4 \mathrm{H}-6-80$ & 32.60 & 0.00 & 0.57 & 4.92 & 0.05 & 0.46 \\
\hline $4 \mathrm{H}-6-100$ & 32.80 & 0.00 & 0.00 & 4.55 & 0.03 & 0.68 \\
\hline $4 \mathrm{H}-6-120$ & 33.00 & 0.00 & 0.02 & 10.07 & 0.10 & 1.61 \\
\hline $4 \mathrm{H}-6-140$ & 33.20 & 0.00 & 6.76 & 9.83 & 0.16 & 2.44 \\
\hline $4 \mathrm{H}-7-20$ & 33.50 & 0.00 & 0.02 & 9.97 & 0.12 & 1.20 \\
\hline $4 \mathrm{H}-7-40$ & 33.70 & 0.00 & 0.06 & 8.05 & 0.12 & 1.91 \\
\hline $5 \mathrm{H}-1-17$ & 33.97 & 0.00 & 0.01 & 2.72 & 0.04 & 0.58 \\
\hline $5 \mathrm{H}-1-42$ & 34.22 & 0.00 & 0.00 & 1.53 & 0.07 & 0.31 \\
\hline $5 \mathrm{H}-1-62$ & 34.42 & 0.00 & 0.02 & 3.38 & 0.02 & 0.82 \\
\hline $5 \mathrm{H}-1-82$ & 34.62 & 0.00 & 0.00 & 7.80 & 0.08 & 0.94 \\
\hline $5 \mathrm{H}-1-102$ & 34.82 & 0.00 & 0.00 & 18.65 & 0.66 & 1.66 \\
\hline $5 \mathrm{H}-1-123$ & 35.03 & 0.00 & 0.00 & 14.97 & 0.20 & 1.89 \\
\hline $5 \mathrm{H}-1-142$ & 35.22 & 0.02 & 0.00 & 10.24 & 0.29 & 1.36 \\
\hline $5 \mathrm{H}-2-17$ & 35.47 & 0.00 & 0.00 & 9.83 & 0.16 & 1.42 \\
\hline $5 \mathrm{H}-2-42$ & 35.72 & 0.00 & 0.00 & 6.52 & 0.11 & 0.50 \\
\hline $5 \mathrm{H}-2-62$ & 35.92 & 0.00 & 0.00 & 3.21 & 0.07 & 0.23 \\
\hline $5 \mathrm{H}-2-82$ & 36.12 & 0.00 & 0.00 & 8.81 & 0.25 & 1.23 \\
\hline $5 \mathrm{H}-2-102$ & 36.32 & 0.00 & 0.00 & 5.94 & 0.13 & 0.59 \\
\hline $5 \mathrm{H}-2-123$ & 36.43 & 0.00 & 0.00 & 3.92 & 0.24 & 0.77 \\
\hline $5 \mathrm{H}-2-142$ & 36.61 & 0.00 & 0.00 & 6.02 & 0.15 & 0.36 \\
\hline $5 \mathrm{H}-3-17$ & 36.97 & 0.00 & 0.02 & 9.68 & 0.73 & 0.36 \\
\hline $5 \mathrm{H}-3-42$ & 37.22 & 0.00 & 0.00 & 5.42 & 0.34 & 0.61 \\
\hline $5 \mathrm{H}-3-62$ & 37.42 & 0.00 & 0.00 & 4.17 & 0.29 & 0.39 \\
\hline $5 \mathrm{H}-3-82$ & 37.62 & 0.00 & 0.00 & 10.13 & 0.83 & 1.07 \\
\hline $5 \mathrm{H}-3-102$ & 37.82 & 0.00 & 0.00 & 10.75 & 0.83 & 1.46 \\
\hline $5 \mathrm{H}-3-142$ & 38.22 & 0.00 & 0.00 & 8.29 & 0.35 & 0.65 \\
\hline $5 \mathrm{H}-4-17$ & 38.47 & 0.40 & 0.01 & 6.34 & 0.15 & 0.16 \\
\hline $5 \mathrm{H}-4-42$ & 38.72 & 0.04 & 0.00 & 7.90 & 0.19 & 0.19 \\
\hline $5 \mathrm{H}-4-82$ & 39.12 & 0.00 & 0.00 & 7.88 & 0.12 & 0.18 \\
\hline $5 \mathrm{H}-4-102$ & 39.32 & 0.06 & 0.00 & 5.40 & 0.04 & 0.20 \\
\hline $5 \mathrm{H}-4-123$ & 39.43 & 0.02 & 0.00 & 9.77 & 0.11 & 0.60 \\
\hline $5 \mathrm{H}-4-143$ & 39.62 & 0.00 & 0.00 & 10.74 & 0.21 & 0.64 \\
\hline $5 \mathrm{H}-5-17$ & 39.97 & 0.00 & 0.02 & 9.27 & 0.23 & 0.34 \\
\hline $5 \mathrm{H}-5-42$ & 40.22 & 0.00 & 0.00 & 0.00 & 0.00 & 0.00 \\
\hline $5 \mathrm{H}-5-62$ & 40.42 & 0.00 & 0.00 & 7.57 & 0.07 & 1.12 \\
\hline $5 \mathrm{H}-5-82$ & 40.62 & 0.00 & 0.00 & 4.96 & 0.06 & 0.52 \\
\hline $5 \mathrm{H}-5-102$ & 40.82 & 0.00 & 0.00 & 4.93 & 0.09 & 0.72 \\
\hline $5 \mathrm{H}-5-123$ & 41.03 & 0.00 & 0.00 & 4.76 & 0.16 & 0.81 \\
\hline $5 \mathrm{H}-6-17$ & 41.47 & 0.01 & 0.00 & 5.33 & 0.29 & 0.64 \\
\hline $5 \mathrm{H}-6-42$ & 41.72 & 0.00 & 0.00 & 6.06 & 0.27 & 1.18 \\
\hline $5 \mathrm{H}-6-62$ & 41.92 & 0.00 & 0.00 & 3.03 & 0.09 & 0.45 \\
\hline $5 \mathrm{H}-6-82$ & 42.12 & 0.00 & 0.00 & 3.17 & 0.04 & 0.68 \\
\hline $5 \mathrm{H}-6-102$ & 42.32 & 0.00 & 0.00 & 4.24 & 0.07 & 0.43 \\
\hline $5 \mathrm{H}-6-122$ & 42.42 & 0.00 & 0.00 & 11.89 & 0.36 & 0.96 \\
\hline $5 \mathrm{H}-6-142$ & 42.62 & 0.00 & 0.00 & 8.40 & 0.14 & 1.00 \\
\hline $6 \mathrm{H}-1-20$ & 43.50 & 0.00 & 1.13 & 12.84 & 0.19 & 1.46 \\
\hline $6 \mathrm{H}-1-42$ & 43.70 & 0.00 & 0.00 & 7.90 & 0.10 & 0.47 \\
\hline $6 H-1-61$ & 43.91 & 0.00 & 0.00 & 10.99 & 0.20 & 1.26 \\
\hline $6 \mathrm{H}-1-83$ & 44.13 & 0.00 & 0.34 & 11.52 & 0.25 & 0.74 \\
\hline $6 \mathrm{H}-1-102$ & 44.32 & 0.00 & 0.01 & 3.61 & 0.06 & 0.37 \\
\hline $6 \mathrm{H}-1-120$ & 44.50 & 0.02 & 0.05 & 7.95 & 0.41 & 1.38 \\
\hline
\end{tabular}


Table A3 (continue).

\begin{tabular}{|c|c|c|c|c|c|c|}
\hline Section & $\begin{array}{l}\text { Depth } \\
\text { (mbsf) }\end{array}$ & $\begin{array}{l}\% \text { Benthic } \\
\text { foram. }\end{array}$ & $\begin{array}{l}\% \text { Planktonic } \\
\text { foram. }\end{array}$ & $\begin{array}{c}\% \\
\text { Quartz }\end{array}$ & $\begin{array}{c}\% \\
\text { Feldspar }\end{array}$ & $\begin{array}{c}\% \text { Rock } \\
\text { fragments }\end{array}$ \\
\hline \multicolumn{7}{|c|}{ Hole 643A: Coarse-fraction composition (subfraction $125 \mu \mathrm{m}-5 \mathrm{OO} \mu \mathrm{m}$ ) (Cont.) } \\
\hline $6 \mathrm{H}-1-142$ & 44.72 & 0.00 & 0.00 & 6.54 & 0.12 & 0.52 \\
\hline $6 \mathrm{H}-2-20$ & 45.00 & 0.00 & 0.00 & 4.33 & 0.11 & 0.63 \\
\hline $6 \mathrm{H}-2-42 ?$ & 45.22 & 0.00 & 0.24 & 2.55 & 0.05 & 0.42 \\
\hline $6 \mathrm{H}-2-61$ & 45.44 & 0.00 & 0.00 & 16.43 & 0.18 & 0.66 \\
\hline $6 \mathrm{H}-2-102$ & 45.82 & 0.00 & 0.00 & 11.08 & 0.39 & 0.93 \\
\hline $6 \mathrm{H}-2-120$ & 46.00 & 0.00 & 0.03 & 11.76 & 0.33 & 0.73 \\
\hline $6 \mathrm{H}-2-142$ & 46.20 & 0.00 & 0.04 & 17.47 & 0.20 & 0.90 \\
\hline $6 \mathrm{H}-3-20$ & 46.50 & 0.00 & 0.00 & 2.81 & 0.04 & 0.30 \\
\hline $6 \mathrm{H}-3-42$ & 46.72 & 0.00 & 0.00 & 7.36 & 0.03 & 0.99 \\
\hline $6 \mathrm{H}-3-61$ & 46.90 & 0.00 & 0.00 & 2.73 & 0.07 & 0.29 \\
\hline $6 \mathrm{H}-3-83$ & 47.13 & 0.00 & 0.00 & 3.61 & 0.09 & 0.38 \\
\hline $6 \mathrm{H}-3-102$ & 47.32 & 0.00 & 0.00 & 3.62 & 0.10 & 0.55 \\
\hline $6 \mathrm{H}-3-120$ & 47.50 & 0.00 & 0.01 & 1.57 & 0.05 & 0.20 \\
\hline $6 \mathrm{H}-3-142$ & 47.72 & 0.00 & 0.00 & 3.11 & 0.05 & 0.47 \\
\hline $6 \mathrm{H}-4-20$ & 48.00 & 0.00 & 0.00 & 7.13 & 0.12 & 1.12 \\
\hline $6 \mathrm{H}-4-42$ & 48.22 & 0.00 & 0.00 & 7.95 & 0.02 & 1.35 \\
\hline $6 \mathrm{H}-4-61$ & 48.40 & 0.00 & 0.00 & 5.37 & 0.08 & 0.70 \\
\hline $6 \mathrm{H}-4-83$ & 48.63 & 0.00 & 0.00 & 9.50 & 0.32 & 1.76 \\
\hline $6 \mathrm{H}-4-102$ & 48.82 & 0.00 & 0.04 & 12.59 & 0.25 & 3.64 \\
\hline $6 \mathrm{H}-4-120$ & 49.01 & 0.00 & 0.00 & 4.55 & 0.14 & 0.44 \\
\hline $6 \mathrm{H}-5-20$ & 49.50 & 0.00 & 0.00 & 2.82 & 0.06 & 0.30 \\
\hline $6 \mathrm{H}-5-42$ & 49.72 & 0.00 & 0.00 & 6.09 & 0.18 & 1.56 \\
\hline $6 \mathrm{H}-5-61$ & 49.90 & 0.00 & 0.00 & 3.45 & 0.14 & 0.81 \\
\hline $6 \mathrm{H}-5-83$ & 50.13 & 0.00 & 0.00 & 10.58 & 0.20 & 0.82 \\
\hline $6 \mathrm{H}-5-102$ & 50.32 & 0.00 & 0.00 & 5.43 & 0.03 & 1.05 \\
\hline $6 \mathrm{H}-5-120$ & 50.50 & 0.00 & 0.00 & 6.98 & 0.29 & 1.00 \\
\hline $6 \mathrm{H}-5-142$ & 50.72 & 0.00 & 0.00 & 5.11 & 0.44 & 1.30 \\
\hline $6 \mathrm{H}-6-20$ & 51.00 & 0.00 & 0.00 & 2.15 & 0.24 & 0.70 \\
\hline $6 \mathrm{H}-6-42$ & 51.22 & 0.00 & 0.00 & 1.19 & 0.08 & 0.31 \\
\hline $6 \mathrm{H}-6-46$ & 51.26 & 0.00 & 0.01 & 3.73 & 0.13 & 1.03 \\
\hline $6 \mathrm{H}-6-60$ & 51.40 & 0.00 & 0.00 & 0.94 & 0.06 & 0.23 \\
\hline $7 \mathrm{H}-1-21$ & 53.01 & 0.02 & 0.00 & 3.09 & 0.17 & 0.79 \\
\hline Section & $\begin{array}{l}\text { Depth } \\
\text { (mbsf) }\end{array}$ & $\begin{array}{l}>63 \\
\mu \mathrm{m}\end{array}$ & $\begin{array}{c}125-500 \\
\mu \mathrm{m}\end{array}$ & $\begin{array}{c}500-1000 \\
\mu \mathrm{m}\end{array}$ & $\begin{array}{c}>1000 \\
\mu \mathrm{m}\end{array}$ & \\
\hline
\end{tabular}

Hole 643A Coarse-fraction: weight percentages of subfractions

$\begin{array}{lrrrrrr}1 \mathrm{H}-1-20 & 0.20 & 10.81 & 49.70 & 47.57 & 2.24 & 0.48 \\ 1 \mathrm{H}-1-40 & 0.40 & 25.37 & 50.21 & 45.44 & 2.67 & 1.68 \\ 1 \mathrm{H}-1-60 & 0.60 & 4.95 & 74.72 & 24.15 & 1.11 & 0.02 \\ 1 \mathrm{H}-1-81 & 0.80 & 9.01 & 65.72 & 32.95 & 1.21 & 0.12 \\ 1 \mathrm{H}-1-101 & 1.01 & 5.64 & 62.20 & 33.56 & 3.81 & 0.43 \\ 1 \mathrm{H}-1-121 & 1.21 & 21.29 & 56.01 & 42.90 & 0.88 & 0.21 \\ 1 \mathrm{H}-1-141 & 1.41 & 24.87 & 33.67 & 64.78 & 0.71 & 0.84 \\ 1 \mathrm{H}-2-20 & 1.70 & 26.81 & 79.30 & 20.20 & 0.28 & 0.22 \\ 1 \mathrm{H}-2-41 & 1.90 & 19.33 & 71.48 & 27.34 & 1.09 & 0.09 \\ 1 \mathrm{H}-2-64 & 2.14 & 37.37 & 54.30 & 45.04 & 0.17 & 0.49 \\ 1 \mathrm{H}-2-81 & 2.31 & 30.63 & 17.23 & 81.48 & 0.78 & 0.51 \\ 1 \mathrm{H}-2-101 & 2.51 & 27.59 & 19.72 & 78.32 & 1.06 & 0.89 \\ 1 \mathrm{H}-3-62 & 3.62 & 21.61 & 94.11 & 5.10 & 0.48 & 0.30 \\ 1 \mathrm{H}-3-101 & 4.01 & 13.29 & 51.80 & 44.37 & 2.71 & 1.12 \\ 1 \mathrm{H}-3-121 & 4.21 & 15.44 & 59.66 & 34.79 & 4.40 & 1.15 \\ 1 \mathrm{H}-3-141 & 4.41 & 18.33 & 66.92 & 25.17 & 0.75 & 7.15 \\ 1 \mathrm{H}-4-21 & 4.71 & 29.08 & 50.98 & 46.86 & 1.61 & 0.55 \\ 1 \mathrm{H}-4-41 & 4.91 & 16.70 & 50.64 & 43.86 & 4.90 & 0.60 \\ 2 \mathrm{H}-1-21 & 5.31 & 17.31 & 53.00 & 45.13 & 1.59 & 0.28 \\ 2 \mathrm{H}-1-40 & 5.70 & 24.82 & 25.17 & 70.73 & 1.38 & 2.73 \\ 2 \mathrm{H}-1-60 & 5.90 & 9.54 & 34.26 & 64.60 & 1.00 & 0.14 \\ 2 \mathrm{H}-1-82 & 6.12 & 18.23 & 66.30 & 30.16 & 1.96 & 1.58 \\ 2 \mathrm{H}-1-100 & 6.30 & 20.90 & 58.84 & 36.56 & 3.38 & 1.21 \\ 2 \mathrm{H}-1-120 & 6.50 & 5.83 & 36.52 & 62.13 & 1.27 & 0.08 \\ 2 \mathrm{H}-1-142 & 6.72 & 21.53 & 14.77 & 84.60 & 0.58 & 0.05 \\ 2 \mathrm{H}-2-40 & 7.20 & 11.13 & 41.27 & 57.76 & 0.95 & 0.02 \\ 2 \mathrm{H}-2-60 & 7.40 & 13.34 & 66.74 & 30.97 & 1.88 & 0.41 \\ 2 \mathrm{H}-2-82 & 7.62 & 17.70 & 26.77 & 71.60 & 1.44 & 0.19 \\ 2 \mathrm{H}-2-100 & 7.80 & 9.30 & 59.57 & 38.31 & 1.97 & 0.15 \\ 2 \mathrm{H}-2-120 & 8.00 & 9.17 & 63.84 & 33.02 & 2.54 & 0.60 \\ 2 \mathrm{H}-3-21 & 8.51 & 1.10 & 99.96 & 0.00 & 0.00 & 0.04 \\ 2 \mathrm{H}-3-40 & 8.70 & 2.93 & 44.64 & 55.16 & 0.20 & 0.00 \\ 2 \mathrm{H}-3-60 & 8.90 & 12.62 & 31.98 & 65.60 & 2.26 & 0.15 \\ 2 \mathrm{H}-3-82 & 9.12 & 6.83 & 3.93 & 38.76 & 56.26 & 1.05 \\ 2 \mathrm{H}-3-100 & 9.30 & 11.21 & 45.59 & 53.32 & 1.04 & 0.05 \\ 2 \mathrm{H}-3-120 & 9.50 & 21.16 & 28.36 & 69.36 & 0.68 & 1.60\end{array}$


Table A3 (continued).

\begin{tabular}{|c|c|c|c|c|c|c|}
\hline Section & $\begin{array}{l}\text { Depth } \\
\text { (mbsf) }\end{array}$ & $\begin{array}{l}>63 \\
\mu \mathrm{m}\end{array}$ & $\begin{array}{c}63-125 \\
\mu \mathrm{m}\end{array}$ & $\begin{array}{c}125-500 \\
\mu \mathrm{m}\end{array}$ & $\begin{array}{c}500-1000 \\
\mu \mathrm{m}\end{array}$ & $\begin{array}{c}>1000 \\
\mu \mathrm{m}\end{array}$ \\
\hline \multicolumn{7}{|c|}{ Hole 643A Coarse-fraction: weight percentages of subfractions (Cont.) } \\
\hline $2 \mathrm{H}-3-142$ & 9.72 & 16.53 & 45.21 & 50.98 & 2.00 & 1.81 \\
\hline $2 \mathrm{H}-4-21$ & 10.01 & 10.40 & 32.44 & 67.06 & 0.49 & 0.01 \\
\hline $2 \mathrm{H}-4-40$ & 10.20 & 1.48 & 58.47 & 41.53 & 0.00 & 0.00 \\
\hline $2 \mathrm{H}-4-60$ & 10.40 & 0.20 & 52.74 & 47.26 & 0.00 & 0.00 \\
\hline $2 \mathrm{H}-4-82$ & 10.62 & 24.70 & 45.89 & 52.75 & 1.06 & 0.30 \\
\hline $2 \mathrm{H}-4-120$ & 11.00 & 6.90 & 59.79 & 33.61 & 5.86 & 0.74 \\
\hline $2 \mathrm{H}-5-21$ & 11.51 & 14.40 & 58.90 & 40.64 & 0.34 & 0.12 \\
\hline $2 \mathrm{H}-5-40$ & 11.70 & 15.84 & 62.75 & 34.97 & 1.90 & 0.38 \\
\hline $2 \mathrm{H}-5-60$ & 11.90 & 20.95 & 98.53 & 0.00 & 1.28 & 0.19 \\
\hline $2 \mathrm{H}-5-82$ & 12.12 & 13.62 & 38.37 & 57.12 & 1.83 & 2.68 \\
\hline $2 \mathrm{H}-5-100$ & 12.30 & 10.50 & 17.87 & 80.66 & 1.30 & 0.17 \\
\hline $2 \mathrm{H}-5-120$ & 12.50 & 11.50 & 53.00 & 44.22 & 2.32 & 0.46 \\
\hline $2 \mathrm{H}-5-142$ & 12.72 & 15.68 & 15.20 & 83.84 & 0.94 & 0.02 \\
\hline $2 \mathrm{H}-6-21$ & 13.01 & 10.87 & 30.78 & 68.94 & 0.28 & 0.00 \\
\hline $2 \mathrm{H}-6-40$ & 13.20 & 16.40 & 49.19 & 50.25 & 0.57 & 0.00 \\
\hline $2 \mathrm{H}-6-60$ & 13.40 & 2.50 & 60.13 & 37.65 & 2.22 & 0.00 \\
\hline $2 \mathrm{H}-6-82$ & 13.62 & 2.55 & 47.75 & 49.46 & 2.80 & 0.00 \\
\hline $2 \mathrm{H}-6-111$ & 13.91 & 9.24 & 46.86 & 50.97 & 1.85 & 0.32 \\
\hline $2 \mathrm{H}-6-120$ & 14.00 & 6.20 & 76.90 & 22.07 & 0.95 & 0.08 \\
\hline $2 \mathrm{H}-6-142$ & 14.22 & 20.32 & 71.12 & 26.52 & 1.52 & 0.84 \\
\hline $2 \mathrm{H}-7-21$ & 14.51 & 23.40 & 52.95 & 46.70 & 0.31 & 0.04 \\
\hline $2 \mathrm{H}-7-40$ & 14.70 & 6.42 & 60.71 & 35.78 & 2.63 & 0.88 \\
\hline $3 \mathrm{H}-1-25$ & 15.05 & 18.09 & 29.38 & 69.55 & 0.74 & 0.33 \\
\hline $3 \mathrm{H}-1-42$ & 15.21 & 9.10 & 48.24 & 49.56 & 1.96 & 0.24 \\
\hline $3 \mathrm{H}-2-20$ & 16.50 & 8.70 & 25.79 & 73.07 & 1.13 & 0.02 \\
\hline $3 \mathrm{H}-2-42$ & 16.72 & 11.14 & 37.02 & 58.74 & 3.48 & 0.75 \\
\hline $3 \mathrm{H}-2-60$ & 16.90 & 19.61 & 27.25 & 70.95 & 1.70 & 0.10 \\
\hline $3 \mathrm{H}-2-82$ & 17.12 & 15.11 & 42.07 & 56.01 & 1.83 & 0.09 \\
\hline $3 \mathrm{H}-2-101$ & 17.31 & 2.63 & 65.50 & 33.00 & 1.50 & 0.01 \\
\hline $3 \mathrm{H}-2-120$ & 17.50 & 7.11 & 50.43 & 42.84 & 6.46 & 0.27 \\
\hline $3 \mathrm{H}-2-142$ & 17.72 & 20.10 & 51.28 & 44.01 & 3.11 & 1.60 \\
\hline $3 \mathrm{H}-3-20$ & 18.00 & 6.84 & 63.20 & 34.16 & 2.44 & 0.20 \\
\hline $3 \mathrm{H}-3-25$ & 18.05 & 19.68 & 80.99 & 18.72 & 0.26 & 0.04 \\
\hline $3 \mathrm{H}-3 \cdot 40$ & 18.20 & 4.40 & 53.71 & 44.74 & 1.41 & 0.14 \\
\hline $3 \mathrm{H}-3-58$ & 18.38 & 17.97 & 44.60 & 53.37 & 1.73 & 0.30 \\
\hline $3 \mathrm{H}-3-82$ & 18.62 & 0.69 & 58.98 & 39.69 & 1.33 & 0.01 \\
\hline $3 \mathrm{H}-3-100$ & 18.80 & 1.45 & 72.32 & 24.65 & 2.79 & 0.24 \\
\hline $3 \mathrm{H}-3-116$ & 18.96 & 2.00 & 73.31 & 26.69 & 0.00 & 0.00 \\
\hline $3 \mathrm{H}-3-121$ & 19.03 & 8.92 & 54.29 & 42.92 & 2.52 & 0.27 \\
\hline $3 \mathrm{H}-4-20$ & 19.50 & 16.60 & 43.49 & 50.54 & 5.16 & 0.81 \\
\hline $3 \mathrm{H}-4-42$ & 19.72 & 2.68 & 65.46 & 31.06 & 3.29 & 0.19 \\
\hline $3 \mathrm{H}-4-58$ & 19.88 & 2.30 & 80.32 & 17.66 & 1.65 & 0.37 \\
\hline $3 \mathrm{H}-4-82$ & 20.12 & 3.10 & 80.54 & 18.04 & 1.42 & 0.00 \\
\hline $3 \mathrm{H}-4-100$ & 20.30 & 11.76 & 57.37 & 39.21 & 3.11 & 0.32 \\
\hline $3 \mathrm{H}-4-122$ & 20.52 & 14.78 & 15.60 & 83.99 & 0.38 & 0.03 \\
\hline $3 \mathrm{H}-4-142$ & 20.72 & 6.33 & 77.04 & 22.04 & 0.88 & 0.04 \\
\hline $3 \mathrm{H}-5-20$ & 21.00 & 2.41 & 64.20 & 32.86 & 2.94 & 0.00 \\
\hline $3 \mathrm{H}-5-40$ & 21.20 & 10.41 & 67.08 & 31.85 & 0.94 & 0.14 \\
\hline $3 \mathrm{H}-5-58$ & 21.38 & 6.44 & 15.67 & 81.61 & 2.64 & 0.08 \\
\hline $3 \mathrm{H}-5-82$ & 21.62 & 6.30 & 78.39 & 19.48 & 2.06 & 0.07 \\
\hline $3 \mathrm{H}-5-100$ & 21.80 & 4.11 & 65.48 & 32.83 & 1.62 & 0.08 \\
\hline $3 \mathrm{H}-5-120$ & 22.00 & 12.18 & 64.46 & 33.25 & 1.86 & 0.43 \\
\hline $3 \mathrm{H}-5-140$ & 22.20 & 6.52 & 49.39 & 49.23 & 1.30 & 0.09 \\
\hline $3 \mathrm{H}-6-20$ & 22.50 & 5.70 & 44.63 & $\cdot 53.34$ & 1.98 & 0.05 \\
\hline $3 \mathrm{H}-6-40$ & 22.70 & 7.70 & 44.53 & 50.60 & 4.85 & 0.02 \\
\hline $3 \mathrm{H}-6-58$ & 22.88 & 12.60 & 67.00 & 31.08 & 1.76 & 0.16 \\
\hline $3 \mathrm{H}-6-82$ & 23.12 & 6.95 & 66.72 & 30.72 & 2.41 & 0.15 \\
\hline $3 \mathrm{H}-6-100$ & 23.30 & 2.98 & 65.51 & 31.93 & 2.51 & 0.05 \\
\hline $3 \mathrm{H}-6-120$ & 23.50 & 3.98 & 72.08 & 26.43 & 1.31 & 0.18 \\
\hline $3 \mathrm{H}-6-140$ & 23.70 & 4.22 & 59.32 & 39.42 & 1.23 & 0.03 \\
\hline $3 \mathrm{H}-7-20$ & 24.00 & 9.10 & 43.30 & 54.77 & 1.82 & 0.11 \\
\hline $3 \mathrm{H}-7-40$ & 24.20 & 14.30 & 46.45 & 51.35 & 1.93 & 0.26 \\
\hline $3 \mathrm{H}-7-56$ & 24.30 & 13.24 & 45.56 & 52.81 & 1.57 & 0.05 \\
\hline $4 \mathrm{H}-1-20$ & 24.50 & 2.10 & 71.16 & 24.52 & 4.25 & 0.07 \\
\hline $4 \mathrm{H}-1-40$ & 24.70 & 4.85 & 54.89 & 41.79 & 2.77 & 0.56 \\
\hline $4 H-1-60$ & 24.90 & 0.83 & 71.47 & 25.43 & 3.10 & 0.00 \\
\hline $4 \mathrm{H}-1-80$ & 25.10 & 4.00 & 70.62 & 25.46 & 3.38 & 0.53 \\
\hline $4 \mathrm{H}-1-94$ & 25.24 & 8.06 & 88.27 & 11.22 & 0.48 & 0.03 \\
\hline $4 \mathrm{H}-1-100$ & 25.30 & 7.10 & 82.87 & 17.12 & 0.00 & 0.01 \\
\hline $4 \mathrm{H}-1-120$ & 25.50 & 6.50 & 78.53 & 21.47 & 0.00 & 0.00 \\
\hline $4 \mathrm{H}-1-140$ & 25.70 & 10.92 & 88.04 & 11.57 & 0.39 & 0.00 \\
\hline $4 \mathrm{H}-2-20$ & 26.00 & 5.40 & 84.62 & 15.34 & 0.00 & 0.04 \\
\hline $4 \mathrm{H}-2-40$ & 26.20 & 3.40 & 66.85 & 26.83 & 6.10 & 0.21 \\
\hline $4 \mathrm{H}-2-60$ & 26.40 & 1.21 & 31.47 & 32.28 & 36.24 & 0.01 \\
\hline $4 \mathrm{H}-2-80$ & 26.60 & 2.50 & 62.80 & 37.15 & 0.00 & 0.05 \\
\hline $4 \mathrm{H}-2-100$ & 26.80 & 8.92 & 52.09 & 47.25 & 0.63 & 0.03 \\
\hline
\end{tabular}


Table A3 (continued).

\begin{tabular}{|c|c|c|c|c|c|c|}
\hline Section & $\begin{array}{l}\text { Depth } \\
\text { (mbsf) }\end{array}$ & $\begin{array}{l}>63 \\
\mu \mathrm{m}\end{array}$ & $\begin{array}{c}63-125 \\
\mu \mathrm{m}\end{array}$ & $\begin{array}{c}125-500 \\
\mu \mathrm{m}\end{array}$ & $\begin{array}{c}500-1000 \\
\mu \mathrm{m}\end{array}$ & $\begin{array}{c}>1000 \\
\mu \mathrm{m}\end{array}$ \\
\hline \multicolumn{7}{|c|}{ Hole 643A Coarse-fraction: weight percentages of subfractions (Cont.) } \\
\hline $4 \mathrm{H}-2-120$ & 27.00 & 6.65 & 62.39 & 37.57 & 0.00 & 0.04 \\
\hline $4 \mathrm{H}-2-140$ & 27.30 & 1.67 & 74.67 & 25.28 & 0.00 & 0.05 \\
\hline $4 \mathrm{H}-3-20$ & 27.50 & 11.50 & 69.05 & 28.56 & 1.85 & 0.55 \\
\hline $4 \mathrm{H}-3-40$ & 27.60 & 2.95 & 74.41 & 23.46 & 2.09 & 0.04 \\
\hline $4 \mathrm{H}-3-60$ & 27.80 & 3.00 & 66.05 & 32.97 & 0.98 & 0.00 \\
\hline $4 \mathrm{H}-3-80$ & 28.00 & 15.83 & 57.98 & 39.51 & 2.28 & 0.23 \\
\hline $4 \mathrm{H}-3-94$ & 28.14 & 7.38 & 59.36 & 36.97 & 3.48 & 0.19 \\
\hline $4 \mathrm{H}-3-100$ & 28.20 & 1.72 & 67.31 & 32.66 & 0.00 & 0.03 \\
\hline $4 \mathrm{H}-3-120$ & 28.40 & 20.04 & 64.27 & 33.32 & 2.07 & 0.34 \\
\hline $4 \mathrm{H}-3-140$ & 28.60 & 14.20 & 29.17 & 69.53 & 1.29 & 0.01 \\
\hline $4 \mathrm{H}-4-20$ & 29.00 & 17.10 & 79.70 & 19.73 & 0.45 & 0.12 \\
\hline $4 \mathrm{H}-4-40$ & 29.20 & 18.20 & 71.85 & 26.71 & 1.19 & 0.24 \\
\hline $4 \mathrm{H}-4-60$ & 29.40 & 3.30 & 73.74 & 26.18 & 0.00 & 0.08 \\
\hline $4 \mathrm{H}-4-80$ & 29.60 & 10.30 & 44.66 & 55.08 & 0.00 & 0.26 \\
\hline $4 \mathrm{H}-4-100$ & 29.80 & 8.30 & 54.25 & 43.16 & 2.19 & 0.40 \\
\hline $4 \mathrm{H}-4-120$ & 30.00 & 6.70 & 74.47 & 25.34 & 0.17 & 0.01 \\
\hline $4 \mathrm{H}-5-18$ & 30.48 & 10.95 & 60.54 & 37.72 & 1.62 & 0.13 \\
\hline $4 \mathrm{H}-5-40$ & 30.70 & 9.04 & 63.00 & 34.63 & 2.10 & 0.27 \\
\hline $4 \mathrm{H}-5-60$ & 30.90 & 17.34 & 59.52 & 38.78 & 0.00 & 1.70 \\
\hline $4 \mathrm{H}-5-80$ & 31.10 & 15.17 & 72.30 & 26.49 & 0.83 & 0.39 \\
\hline $4 \mathrm{H}-5-94$ & 31.24 & 18.40 & 90.28 & 8.00 & 0.00 & 1.72 \\
\hline $4 H-5-100$ & 31.30 & 15.30 & 92.20 & 7.41 & 0.00 & 0.39 \\
\hline $4 \mathrm{H}-5-140$ & 31.70 & 4.80 & 41.99 & 57.98 & 0.00 & 0.03 \\
\hline $4 \mathrm{H}-6-16$ & 31.96 & 8.30 & 66.48 & 33.51 & 0.00 & 0.01 \\
\hline $4 \mathrm{H}-6-40$ & 32.20 & 9.70 & 69.22 & 30.58 & 0.00 & 0.20 \\
\hline $4 H-6-60$ & 32.40 & 15.20 & 82.14 & 17.51 & 0.00 & 0.35 \\
\hline $4 \mathrm{H}-6-80$ & 32.60 & 6.20 & 68.40 & 31.51 & 0.00 & 0.09 \\
\hline $4 \mathrm{H}-6-100$ & 32.80 & 5.50 & 79.01 & 19.28 & 1.57 & 0.14 \\
\hline $4 \mathrm{H}-6-120$ & 33.00 & 12.20 & 46.27 & 47.56 & 5.32 & 0.85 \\
\hline $4 \mathrm{H}-6-140$ & 33.20 & 20.30 & 62.59 & 36.64 & 0.00 & 0.77 \\
\hline $4 \mathrm{H}-7-20$ & 33.50 & 12.40 & 64.68 & 33.92 & 1.26 & 0.14 \\
\hline $4 \mathrm{H}-7-40$ & 33.70 & 10.40 & 68.07 & 29.41 & 2.33 & 0.19 \\
\hline $5 \mathrm{H}-1-17$ & 33.97 & 3.40 & 56.57 & 43.30 & 0.00 & 0.13 \\
\hline $5 \mathrm{H}-1-42$ & 34.22 & 2.00 & 65.66 & 33.07 & 1.10 & 0.16 \\
\hline $5 \mathrm{H}-1-62$ & 34.42 & 4.30 & 56.64 & 40.18 & 3.06 & 0.12 \\
\hline $5 \mathrm{H}-1-82$ & 34.62 & 9.90 & 61.49 & 36.85 & 1.66 & 0.01 \\
\hline $5 \mathrm{H}-1-102$ & 34.82 & 22.10 & 49.84 & 49.12 & 0.91 & 0.13 \\
\hline $5 \mathrm{H}-1-123$ & 35.03 & 17.80 & 68.40 & 28.61 & 2.43 & 0.56 \\
\hline $5 \mathrm{H}-1-142$ & 35.22 & 12.40 & 70.28 & 27.72 & 1.71 & 0.29 \\
\hline $5 \mathrm{H}-2-17$ & 35.47 & 11.60 & 68.53 & 30.90 & 0.48 & 0.09 \\
\hline $5 \mathrm{H}-2-42$ & 35.72 & 7.50 & 59.88 & 37.83 & 1.90 & 0.38 \\
\hline $5 \mathrm{H}-2-62$ & 35.92 & 3.72 & 57.77 & 39.92 & 2.26 & 0.05 \\
\hline $5 \mathrm{H}-2-82$ & 36.12 & 11.82 & 54.89 & 39.20 & 4.98 & 0.93 \\
\hline $5 \mathrm{H}-2-102$ & 36.32 & 7.00 & 51.94 & 45.94 & 2.07 & 0.04 \\
\hline $5 \mathrm{H}-2-123$ & 36.43 & 5.10 & 72.73 & 27.11 & 0.13 & 0.03 \\
\hline $5 \mathrm{H}-2-142$ & 36.61 & 7.10 & 60.77 & 38.30 & 0.90 & 0.04 \\
\hline $5 \mathrm{H}-3-17$ & 36.97 & 12.10 & 67.66 & 31.62 & 0.67 & 0.05 \\
\hline $5 \mathrm{H}-3-42$ & 37.22 & 6.90 & 58.84 & 39.54 & 1.55 & 0.06 \\
\hline $5 \mathrm{H}-3-62$ & 37.42 & 5.00 & 70.54 & 27.87 & 1.59 & 0.00 \\
\hline $5 \mathrm{H}-3-82$ & 37.62 & 12.70 & 59.02 & 39.82 & 0.80 & 0.36 \\
\hline $5 \mathrm{H}-3-102$ & 37.82 & 13.63 & 67.90 & 29.63 & 1.97 & 0.51 \\
\hline $5 \mathrm{H}-3-142$ & 38.22 & 9.90 & 60.52 & 36.98 & 2.33 & 0.17 \\
\hline $5 \mathrm{H}-4-17$ & 38.47 & 7.41 & 70.27 & 28.97 & 0.75 & 0.01 \\
\hline $5 \mathrm{H}-4-42$ & 38.72 & 8.72 & 55.80 & 40.78 & 2.77 & 0.65 \\
\hline $5 \mathrm{H}-4-62$ & 38.92 & 8.57 & 65.54 & 33.03 & 1.18 & 0.25 \\
\hline $5 \mathrm{H}-4-82$ & 39.12 & 8.60 & 78.11 & 21.02 & 0.63 & 0.25 \\
\hline $5 \mathrm{H}-4-102$ & 39.32 & 6.10 & 44.33 & 53.30 & 2.37 & 0.00 \\
\hline $5 \mathrm{H}-4-123$ & 39.43 & 11.40 & 67.43 & 30.42 & 1.99 & 0.16 \\
\hline $5 \mathrm{H}-4-143$ & 39.62 & 12.50 & 69.35 & 28.97 & 1.39 & 0.29 \\
\hline $5 \mathrm{H}-5-17$ & 39.97 & 10.72 & 50.52 & 47.57 & 1.89 & 0.02 \\
\hline $5 \mathrm{H}-5-62$ & 40.42 & 8.88 & 66.66 & 31.19 & 1.48 & 0.68 \\
\hline $5 \mathrm{H}-5-82$ & 40.62 & 5.80 & 53.92 & 43.86 & 2.00 & 0.21 \\
\hline $5 \mathrm{H}-5-102$ & 40.82 & 6.00 & 64.07 & 34.81 & 1.13 & 0.00 \\
\hline $5 \mathrm{H}-5-123$ & 41.03 & 6.05 & 65.74 & 32.66 & 1.50 & 0.10 \\
\hline $5 \mathrm{H}-6-17$ & 41.47 & 6.70 & 66.16 & 32.42 & 1.37 & 0.05 \\
\hline $5 \mathrm{H}-6-42$ & 41.72 & 7.64 & 76.52 & 23.42 & 0.00 & 0.06 \\
\hline $5 \mathrm{H}-6-62$ & 41.92 & 3.89 & 77.96 & 21.71 & 0.33 & 0.00 \\
\hline $5 \mathrm{H}-6-82$ & 42.12 & 4.02 & 2.78 & 93.76 & 3.27 & 0.19 \\
\hline $5 \mathrm{H}-6-102$ & 42.32 & 4.90 & 55.83 & 40.94 & 3.16 & 0.06 \\
\hline $5 \mathrm{H}-6-122$ & 42.42 & 14.50 & 65.62 & 30.32 & 1.67 & 2.40 \\
\hline $5 \mathrm{H}-6-142$ & 42.62 & 10.21 & 60.69 & 34.93 & 3.14 & 1.24 \\
\hline $6 \mathrm{H}-1-20$ & 43.50 & 17.44 & 55.49 & 33.97 & 7.50 & 3.03 \\
\hline $6 \mathrm{H}-1-42$ & 43.70 & 10.40 & 55.51 & 37.98 & 5.61 & 0.90 \\
\hline $6 \mathrm{H}-1-61$ & 43.91 & 13.30 & 63.18 & 34.13 & 2.40 & 0.29 \\
\hline $6 \mathrm{H}-1-83$ & 44.13 & 13.20 & 99.49 & 0.00 & 0.00 & 0.51 \\
\hline $6 \mathrm{H}-1-102$ & 44.32 & 4.20 & 56.18 & 41.88 & 1.78 & 0.16 \\
\hline
\end{tabular}


Table A3 (continued).

\begin{tabular}{|c|c|c|c|c|c|c|}
\hline Section & $\begin{array}{l}\text { Depth } \\
\text { (mbsf) }\end{array}$ & $\begin{array}{l}>63 \\
\mu \mathrm{m}\end{array}$ & $\begin{array}{c}63-125 \\
\mu \mathrm{m}\end{array}$ & $\begin{array}{c}125-500 \\
\mu \mathrm{m}\end{array}$ & $\begin{array}{c}500-1000 \\
\mu \mathrm{m}\end{array}$ & $\begin{array}{c}>1000 \\
\mu \mathrm{m}\end{array}$ \\
\hline \multicolumn{7}{|c|}{ Hole 643A Coarse-fraction: weight percentages of subfractions (Cont.) } \\
\hline $6 \mathrm{H}-1-120$ & 44.50 & 12.10 & 78.87 & 19.96 & 1.01 & 0.16 \\
\hline $6 \mathrm{H}-1-142$ & 44.72 & 8.30 & 69.20 & 29.86 & 0.94 & 0.00 \\
\hline $6 \mathrm{H}-2-20$ & 45.00 & 5.52 & 79.14 & 19.92 & 0.91 & 0.03 \\
\hline $6 \mathrm{H}-2-61$ & 45.44 & 17.82 & 86.35 & 8.24 & 0.00 & 5.41 \\
\hline $6 \mathrm{H}-2-102$ & 45.82 & 13.10 & 69.98 & 28.61 & 1.27 & 0.14 \\
\hline $6 \mathrm{H}-2-120$ & 46.00 & 13.80 & 34.27 & 64.64 & 1.05 & 0.04 \\
\hline $6 \mathrm{H}-2-142$ & 46.20 & 19.50 & 74.58 & 23.59 & 1.63 & 0.20 \\
\hline $6 \mathrm{H}-3-20$ & 46.50 & 3.65 & 67.77 & 31.17 & 1.07 & 0.00 \\
\hline $6 \mathrm{H}-3-42$ & 46.72 & 8.70 & 95.96 & 0.00 & 3.81 & 0.23 \\
\hline $6 \mathrm{H}-3-61$ & 46.90 & 4.70 & 72.81 & 25.87 & 1.26 & 0.06 \\
\hline $6 \mathrm{H}-3-83$ & 47.13 & 6.22 & 76.27 & 21.48 & 2.25 & 0.01 \\
\hline $6 \mathrm{H}-3-102$ & 47.32 & 4.40 & 64.33 & 34.04 & 1.54 & 0.10 \\
\hline $6 \mathrm{H}-3-120$ & 47.50 & 1.98 & 69.41 & 30.59 & 0.00 & 0.00 \\
\hline $6 \mathrm{H}-3-142$ & 47.72 & 4.04 & 54.05 & 43.93 & 1.94 & 0.09 \\
\hline $6 \mathrm{H}-4-20$ & 48.00 & 8.72 & 72.85 & 25.18 & 1.90 & 0.07 \\
\hline $6 \mathrm{H}-4-42$ & 48.22 & 9.70 & 90.00 & 9.69 & 0.29 & 0.02 \\
\hline $6 \mathrm{H}-4-61$ & 48.40 & 6.35 & 57.11 & 42.04 & 0.68 & 0.17 \\
\hline $6 \mathrm{H}-4-83$ & 48.63 & 11.90 & 55.05 & 43.25 & 1.44 & 0.27 \\
\hline $6 \mathrm{H}-4-102$ & 48.82 & 18.87 & 53.96 & 44.47 & 1.19 & 0.38 \\
\hline $6 \mathrm{H}-4-120$ & 49.01 & 5.40 & 53.26 & 44.23 & 2.38 & 0.13 \\
\hline $6 \mathrm{H}-5-20$ & 49.50 & 3.42 & 84.12 & 15.31 & 0.57 & 0.00 \\
\hline $6 \mathrm{H}-5-42$ & 49.72 & 8.20 & 57.85 & 40.03 & 1.89 & 0.23 \\
\hline $6 \mathrm{H}-5-61$ & 49.90 & 5.40 & 60.28 & 36.79 & 2.35 & 0.58 \\
\hline $6 \mathrm{H}-5-83$ & 50.13 & 12.20 & 53.70 & 44.56 & 1.69 & 0.05 \\
\hline $6 \mathrm{H}-5-102$ & 50.32 & 6.70 & 64.95 & 33.09 & 1.88 & 0.08 \\
\hline $6 \mathrm{H}-5-120$ & 50.50 & 9.22 & 61.39 & 36.97 & 1.29 & 0.35 \\
\hline $6 \mathrm{H}-5-142$ & 50.72 & 7.00 & 63.46 & 34.93 & 1.50 & 0.12 \\
\hline $6 \mathrm{H}-6-20$ & 51.00 & 3.44 & 75.47 & 24.19 & 0.25 & 0.09 \\
\hline $6 \mathrm{H}-6-42$ & 51.22 & 1.80 & 77.67 & 22.33 & 0.00 & 0.00 \\
\hline $6 \mathrm{H}-6-46$ & 51.26 & 5.20 & 99.86 & 0.00 & 0.00 & 0.14 \\
\hline $6 \mathrm{H}-6-60$ & 51.40 & 1.34 & 85.06 & 14.94 & 0.00 & 0.00 \\
\hline $6 \mathrm{H}-6-83$ & 51.63 & 2.70 & 100.00 & 0.00 & 0.00 & 0.00 \\
\hline $7 \mathrm{H}-1-21$ & 53.01 & 4.70 & 68.06 & 27.69 & 3.79 & 0.46 \\
\hline $7 \mathrm{H}-1-41$ & 53.21 & 1.82 & 79.58 & 19.12 & 1.07 & 0.23 \\
\hline
\end{tabular}




\section{R. HENRICH}

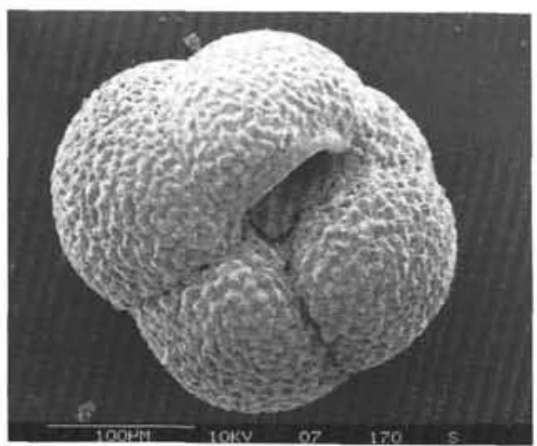

1

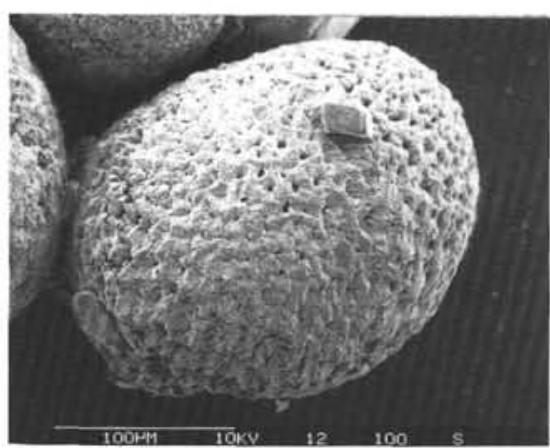

3
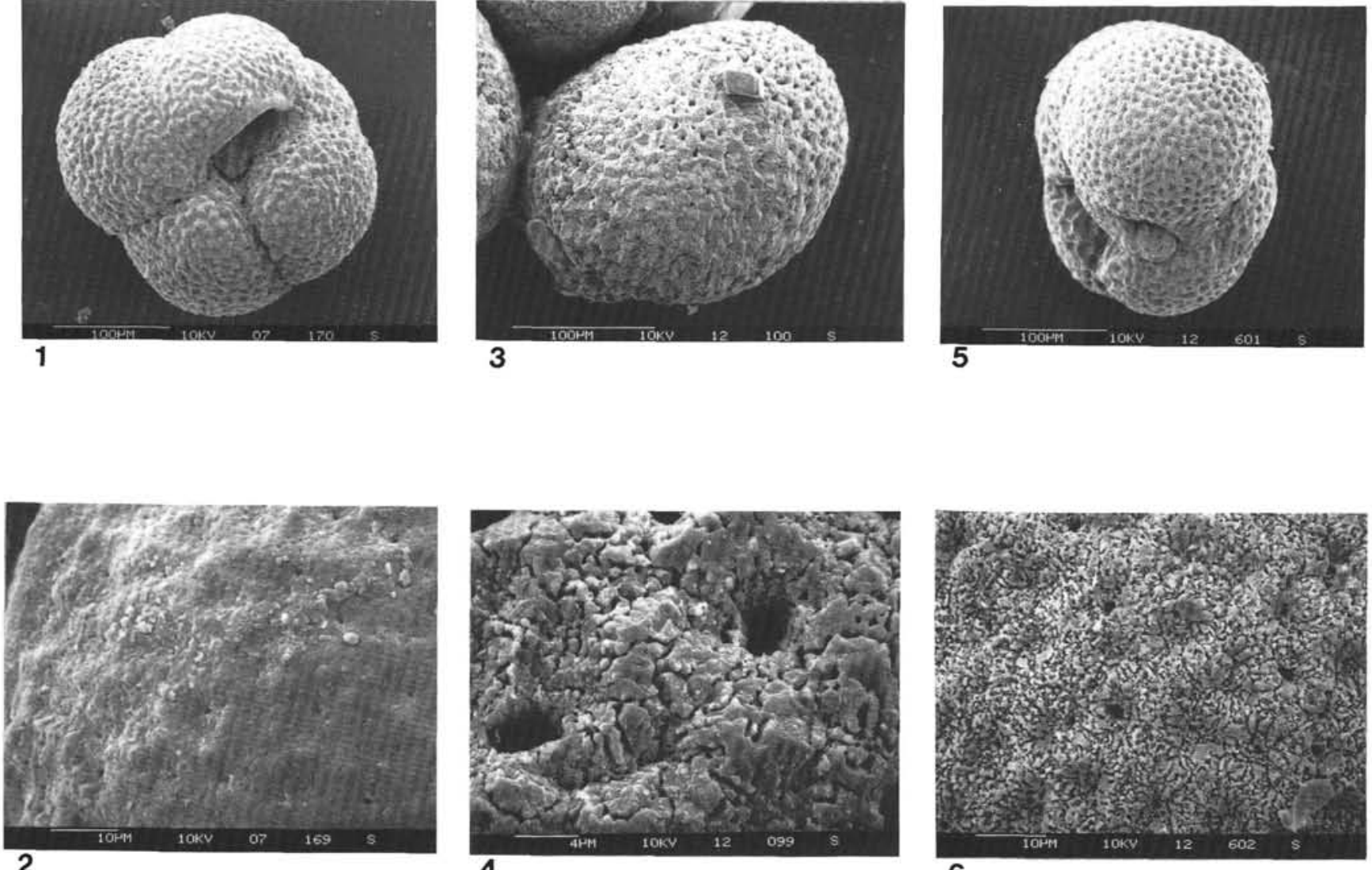

4

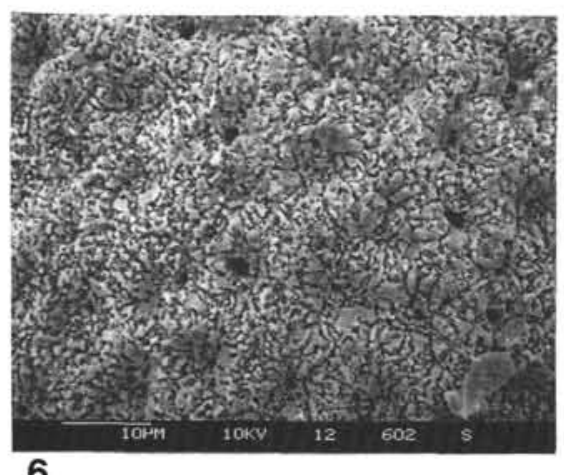

6

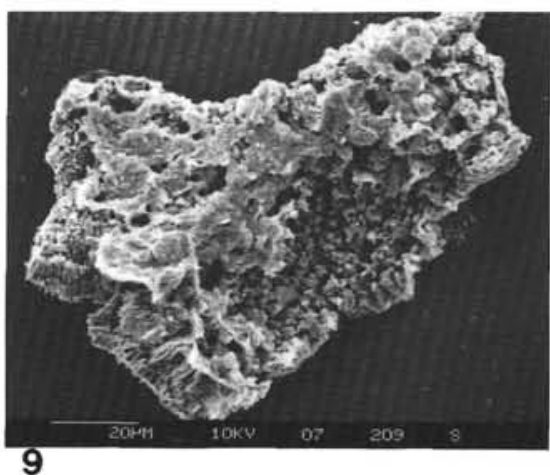

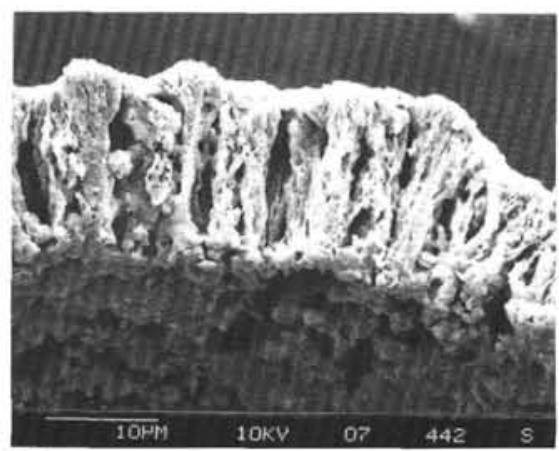

8

9

Plate 1. SEM-dissolution indexes on N. pachyderma sin., reticulate morphotype. 1, 2. Well-preserved reticulate test $\left(\mathrm{D}_{0 \mathrm{~A}}\right)$. 3, 4. Incipient dissolution at the surface of the test $\left(D_{1 A}\right)$. 5, 6. Strong dissolution at the surface of the test $\left(D_{2 A}\right) .7,8$. Strong dissolution starting from the interior parts of the test resulting in fragmentation $\left(D_{3 A}\right)$. 9. Extremely corroded fragment $\left(D_{3 A}\right)$. 


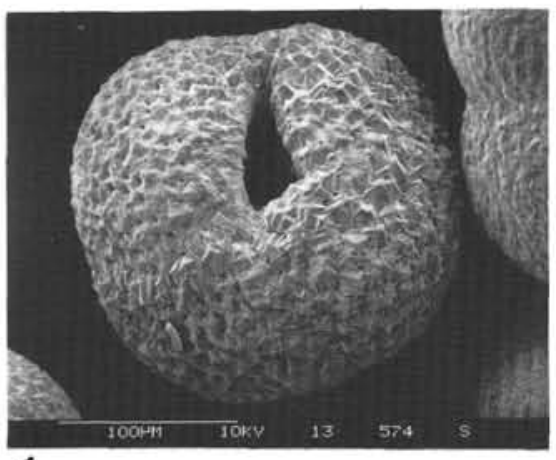

1

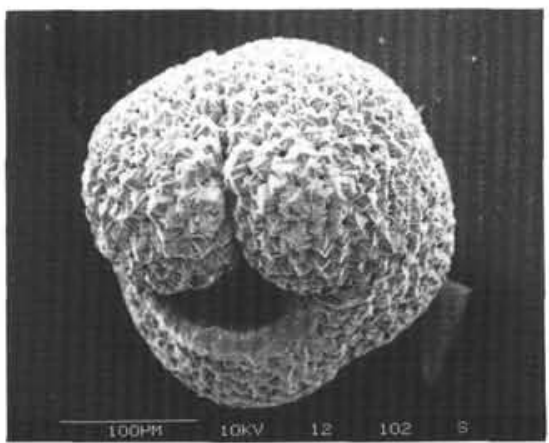

3

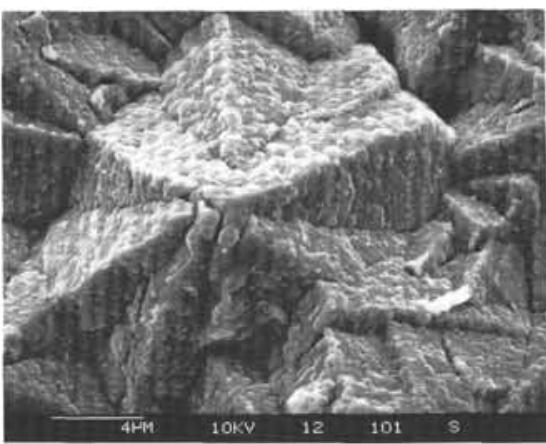

4

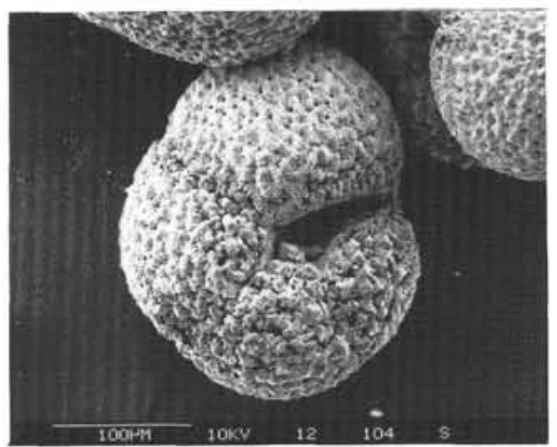

5

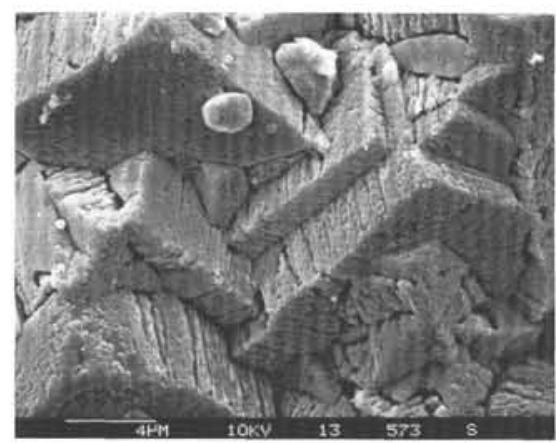

2

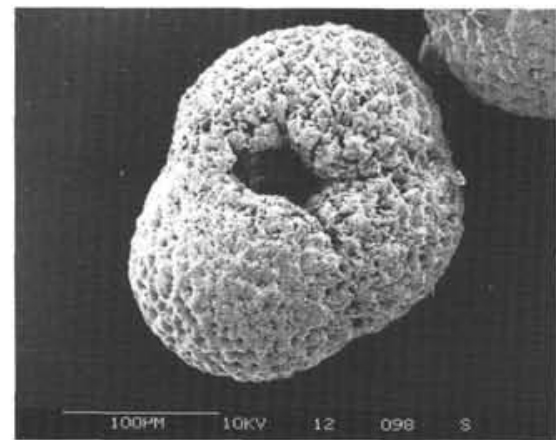

7

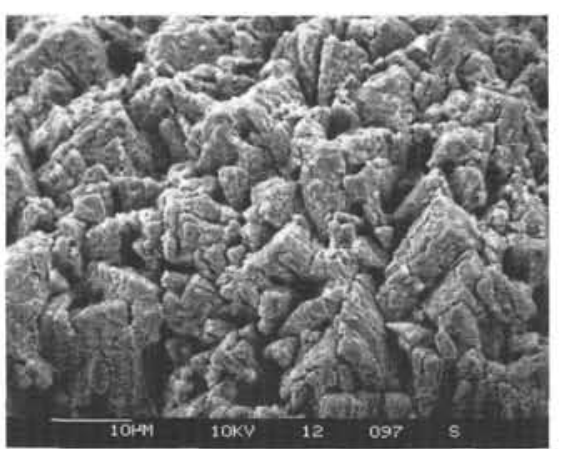

8

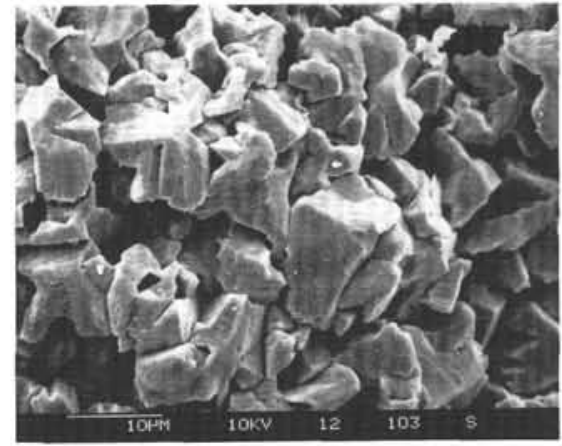

6

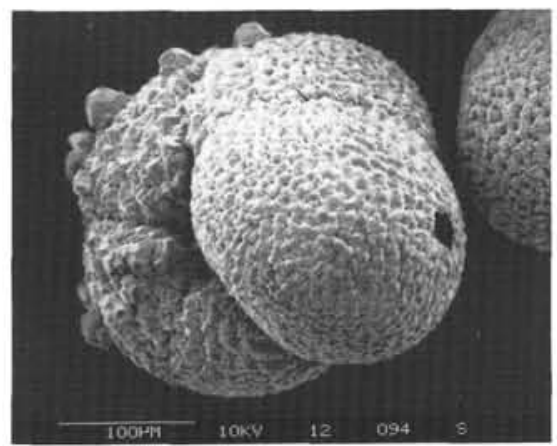

9

Plate 2. SEM-dissolution indexes on $N$. pachyderma sin., crystalline morphotype. 1, 2. Initial dissolution reflecting typical corrosion relief on the surface of the rhomboedra $\left(D_{1 B}\right)$. 3, 4. Initial dissolution on rosette-like rhomboedra aggregate revealing irregular dissolution relief $\left(D_{1 B}\right)$. 5 , 6 . Intermediate dissolution showing strong corrosion of rhomboedra and loosening of the crystal's framework $\left(\mathrm{D}_{2 \mathrm{~B}}\right)$. 7, 8. Strong dissolution with extreme corrosion of rhomboedra and strong loosening of the crystal's framework $\left(\mathrm{D}_{2 \mathrm{~B}}\right)$. 9. Crystalline morphotype, youngest chamber still reflecting fine crystalline reticulations, overgrowth of authigenic carbonate cements. 


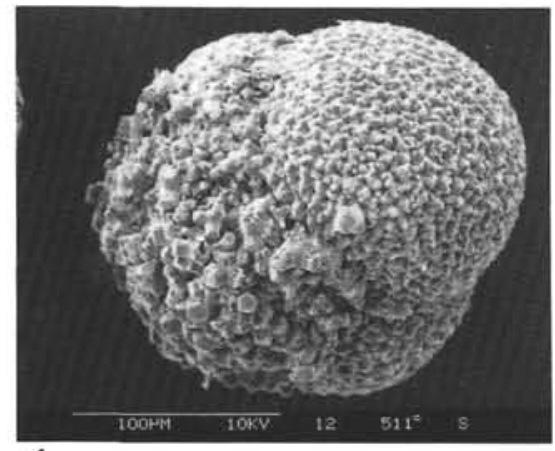

1

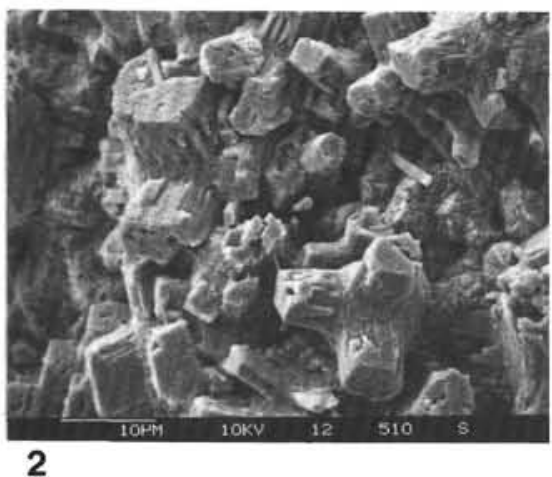

2

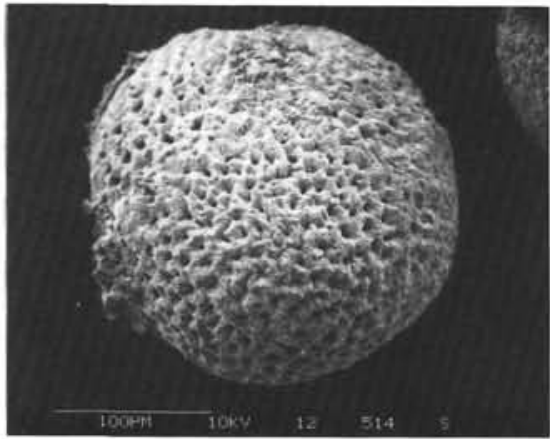

7

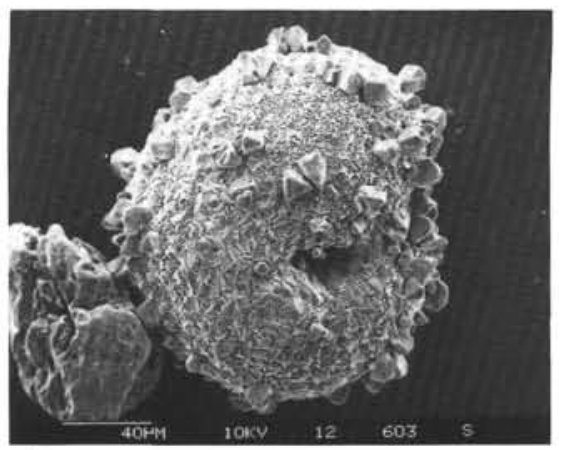

3
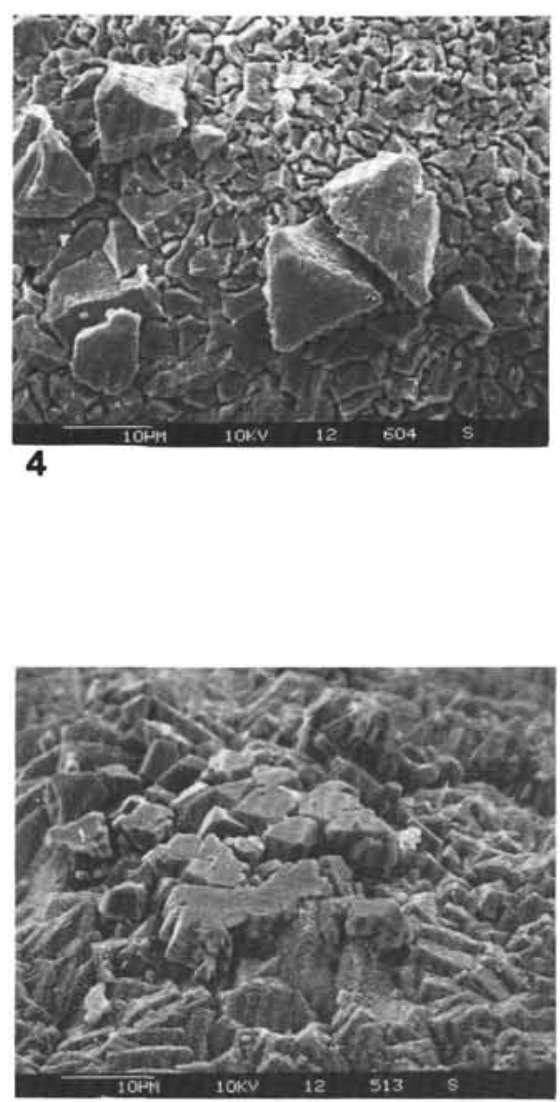

8

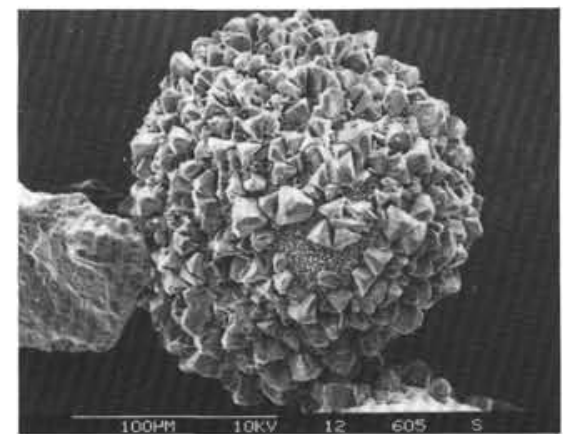

5
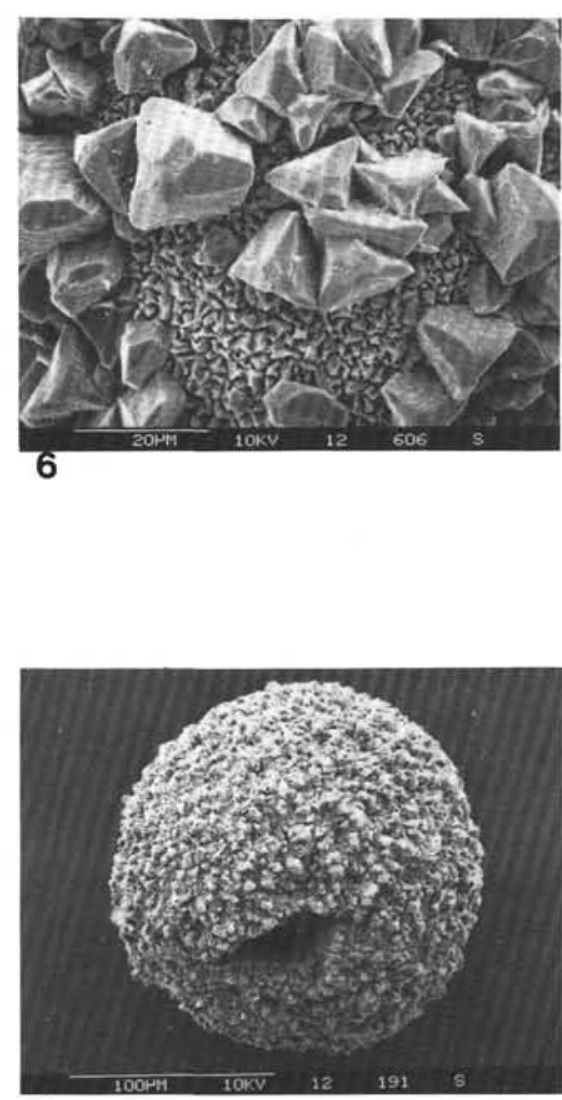

9

Plate 3. Authigenic carbonate cements on $N$. pachyderma sin. 1,2. Aragonite cement (?). 3, 4. Incipiently dissolved authigenic calcite cement on a strongly corroded test. $\mathbf{5 , 6}$. Authigenic calcite cement on a strongly corroded test. $\mathbf{7 , 8}$. Authigenic cement overgrowth on the crystalline morphotype of $N$. pachyderma. 9. Intense authigenic cementation on a reticulate test. 